atility.

\author{
GEOCHEMISTRY RESEARCH PLANNING FOR THE \\ UNDERGROUND STORAGE OF HIGH-LEVEL NUCLEAR WASTE
}

\author{
J.A. Apps \\ Earth Sciences Division \\ Lawrence Berkeley Laboratory \\ Berkeley, California 94720 \\ Operated by the University of California for the \\ U.S. Department of Energy
}

\title{
DISCLAIMER
}

\begin{abstract}
This report was prepared as an account of work sponsored by an agency of the United States Government. Neither the United States Government nor any agency thereof, nor any of their employees, makes any warranty, express or implied, or assumes any legal liability or responsibility for the accuracy, completeness, or usefulness of any information, apparatus, product, or process disclosed, or represents that its use would not infringe privately owned rights. Reference herein to any specilic commercial product, process, or service by trade name, trademark, manufacturer, or otherwise does not necessarily constitute or imply its endorsement, recommendation, or favoring by the United States Government or any agency thereof. The views and opinions of authors expressed herein do not necessatily state or reflect those of the United States Government or any agency thereof.
\end{abstract}

September 1983

\footnotetext{
Prepared for The U. S. Nuclear Regulatory Comolssion, office of Nuclear Material Safety and Safeguards, Division of Waste Management, High-Level Waste Technical Development Branch, under Interagency Agreement DOE 50-80-97 N.R.C. FIN No. B 3109-0; and the U. S. Department of Energy under Contract
No. DE-ACO3-76SFO0098.
} 
This report is a preliminary attempt to plan a comprehensive program of geochemistry research aimed at resolving problems connected with the underground storage of high-level nuclear waste. The problems and research needs were identifled in a companion report to this one, (Apps et al., 1982). The research needs were taken as a point of departure and developed into a series of proposed projects with estimated manpowers and durations.

The scope of the proposed research is based on consideration of an underground repository as a multiple barrier system. However, the program logic and organization reflect conventional strategies for resolving technological problems.

The projects were scheduled and the duration of the program, critical pach projects and distributinn of manpower determined for both full and minimal programs. The proposed research was then compared with ongoing research within DOE, NRC and elswhere to 1dentify omissions in current research. Various options were consldered for altering the scope of the program, and hence its cost and effectiveness. Finally, recommendations were made for dealing with omissions and uncertainties arising from program tmplementation. 
TABLE OF CONTENTS

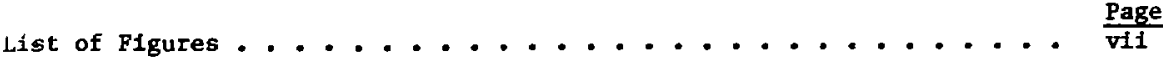

Ligt of Tables. . . . . . . . . . . . . . . . . . . . . . vili

1. Introduction. . . . . . . . . . . . . . . . . . . 1

1.1 Introduction ......................... 1

1.2 Approach to Geochemistry Research Planning . . . . . . . . 4

1.2 .1 objectives .................... 4

1.2.2 Development of a Logical Approach to Research,

Development and Implementation. . . . . . . . . 5

1.2.3 The Waste Repository as a Barrier System. . . . . . . 10

1.3 Development of a Geochemistry Research Plan. . . . . . . . . 11

1.3.1 Stceps Involved In Developing the Plan ........... 11

1.3.2 Level of Research Investigation Required to
Satisfy Regulatory Requirements . . . . . . . . . 14

1.4 Recommendations for Dealing with Uncertainties . . . . . . . 15

1.4.1 Technical Omisstons of the Plan............ 15

1.4.2 Uncertainties Arising for Implementation of the Plan. . . I5

2. Recommended Résearch Plan . . . . . . . . . . . . . . . 16

2.1 Introduction ....................... 16

2.2 Key Research Needs . . . . . . . . . . . . . . . 16

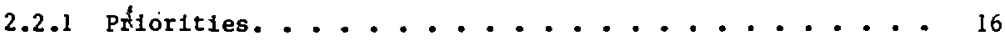

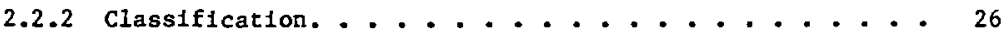

2.2 .3 Level of effort ................... 27

2.2 .4 Time requirements . . . . . . . . . . . . . 27

2.2 .5 Cost...................... 27 
2.3 Comparison with Ongoing Research. . . . . . . . . . . 27

2.4 schedule. . . . . . . . . . . . . . . . . . 91

2.4.1 Development of a schedule. . . . . . . . . . 91

2.4.2 Critical milestones................. 95

2.4.2.1 Milestones determining whether further

research is required.............. 95

2.4.2.2 Milestones defining the scope of further

research. .............. 97

2.4.2.3 Milestones on the critical path........ 98

2.4.3 Overall manpower requirements. . . . . . . . . . . 99

2.4 .4 Resources. . . . . . . . . . . . . . 99

2.5 Options . . . . . . . . . . . . . . . . . . . 103

2.5.1 Stretching out the program ............ 104

2.5.2 Acceleration of the program. . . . . . . . . . 104

2.5.3 Decreasing the scope of research . . . . . . . . 105

2.5.4 Modifying repository specifications. . . . . . . 105

2.5 .5 Summary. . . . . . . . . . . . . . 106

3. Recommendations for Dealing with Limitations and Uncertainties . . 107

3.1 Introduction. . . . . . . . . . . . . . . . 107

3.2 Technical Omissions of the Plan . . . . . . . . . . 107

3.2.1 Natural analogues. . . . . . . . . . . . . 108

3.2.2 Radiolysis ................... 108

3.2.3 Design of laboratory and field experiments . . . . . . 109

3.2 .4 Radionuclide getters . . . . . . . . . . . . 109

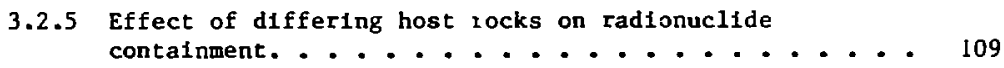


3.2.6 Borehole plugging materials. ............. 109

3.2.7 Transuranic element daughters. . . . . . . . . . 110

3.2.8 Radionuclide adsorption on mineral substrates. . . . . 110

3.2.9 Development of geochemical fleld monitors. . . . . . 110

3.3 Uncertainties Arising from Implementation of the Plan . . . . 110

3.3.1 Implementation ...................... 111

3.3 .2 Manpower ... . . . . . . . . . . . . . . 111

3.3 .3 Costs. ......................... 111

3.3 .4 organization ..................... 111

3.3.5 Timing of Projects within the Program. . . . . . . . 112

3.3.6 Interfacing with other Programs. . . . . . . . . . 112

Acknowledgements . . . . . . . . . . . . . . . . . . . . 114

Appendix A: The Geologic Repository as a Barrier System . . . . . . . 115

Appendix B: List of Research Projects Current in 1981 . . . . . . . . 137

References . . . . . . . . . . . . . . . . . . . . . 194 


\section{LIST OF FIGUFES}

Figure 1.1

Approach to geochemistry research planning for the underground storage of high level nuclear waste. . . . . . .

Figure 1.2

Logic chart to identify geochemfcal needs for the isolation of high level radioactive waste. . . . . . . . 6

Figure 2.1

Schedule

Figure 2.2

Schedule of projects assuming a minimal level of research needs . . . . . . . . . . . . . . . . . 94

Figure 2.3

Manpower requirements for projects . . . . . . . . . . 100

Figure 2.4

Manpower requirements for projects with a minimal level

of research needs. . . . . . . . . . . . . . . . . 102 
viil

\section{LIST OF TABLES}

Table 2.1 . Summary of Problems and Recommendations. . . . . . . . . 17

Table 2.2 proposed projects. . . . . . . . . . . . . . . . 28

Table $2.3 \quad$ Critical Path Projects . . . . . . . . . . . . . 98

Table 2.4 Breakdown of Manpower Requlrements by Year and Major Category of Research Worker. . . . . . . . . . 101 


\section{INIRODUCTION}

\subsection{INTRODUCTION}

An examination of the problem of disposing of high-level radioactive waste underground shows that chemical processes strongly affect waste containment. In this report an attempt is made to develop a plan for conducting geochemistry research to resolve problems relating to this method of disposal. The plan is based on knowledge avallable at the time of preparation, and therefore the conclusions and recommendations presented here are subject to change as more information becomes avallable, or as schedules and priorities for implementation of the waste isolation program change.

This report is the last of three on geochemlstry research sponsored by the Nuclear Regulatory Comission. The first has already been published (Apps et a1., 1982). The second by Carnahan, (1982) is under review. The first report entitled "The Status of Geochemical Problems Relating to the Burial of High-Level Radioactive Waste, 1982", is a companion to this report. It is composed primarily of surveys of existing problems. After each survey, conclusions are drawn and recommendations made regarding the need for future research. The recommendations are used to formulate research proposals. Both the recommendations and the proposals are repeated in this report as a departure point for developing the research plan.

Research planning is an ambitious undertaking, particularly when research, by its very nature, involves uncertalnties as to the final outcoime. Yet the need for new technology for radioactive waste disposal is so great that a directed research effort to this end is called for, especially to resolve major as-yet-unanswered questions in the geochemlstry field.

In planning a research program, it is important to know what are the programmatic and techniral objectives. These are discussed in Section 1.2.1. The objectives cannot be attained without resolving a number of technical questions or issues. Responding to these questions involves a logical progression of steps from inttial definition of tine problems involved through laboratory research, computer simulations, fleld testing and verification, and finally to repository design and construction. Because of the unusual performance requirements for a geologic waste repository, 1.e., waste contalnment for periods of possibly in excess of tens of thousands of years, the research and development needs are more elaborate than needed for conventional engineering design and construction. In Section 1.2.2, the logical progression through research, development, and Implementation is delineated.

The $\log 1 c$ defines the way in which the research program is implemented, and how it is integrated with the repository construction program. However, It does not identify the technical questions holding up repository design. To do this, we need a framework through which the questions can be Identified and related to each other. This is done by considering a repository as a system, which consists of a series of subsystems and components. Section 1.2. 3 analyses the geologic repository as a system of barriers. 
The geochemistry research plan is developed using the repository barrier system as a point of departure, while simultaneously accommodating the logic discussed in Section 1.2.2. The apprcach is outlined in Section 1.3 and discussed in greater detail in Apps et at., 1982 and Chapter 2 of this report. The plan is executed in nine steps:

(1) Review the current status of knowledge regarding the chemical aspects of subsurface waste isolation.

(2) Identify technical questions.

(3) Address and resolve, the technical questions or recommend further research.

(4) Identify speciflc research projects emerging from the recommendations and assign priorities. Classify the research by major

(5) Estimate the level of effort required and duration of each research project.

(6) Compare proposed research with that currently in progress in DOE, MRC and elsewhere.

(7) Identify precursor and successor projects.

(8) Work out schedules.

(9) Consider issues that cannot be resolved in the time frame permitted, and uncertaintles in the program plan.

The plan finally developed in this report contains many individual projects. However, not all aspects of geochemistry were addressed for budgetary and personnel reasons. Therefore, some issues have not received commensurate attention. Individual projects are classified according to basic scientific research topics or research elements rather than according to barrier components, although the logic of the plan as outlined in Section 1.2 .2 is retained. Section 1.3 concludes with a discussion of the level of research investigation required to satisfy regulatory requirements. The final state of planning, which deals with technical omisstons and the uncertainties arising from implementation, is reviewed briefly in Section 1.4 and discussed in greater detail in Chapter 3 of this report.

The sequence of steps in developing the research plan are 1llustrated in Figure 1.1 so that the relationship of each step to the next can be more clearly recognized. 


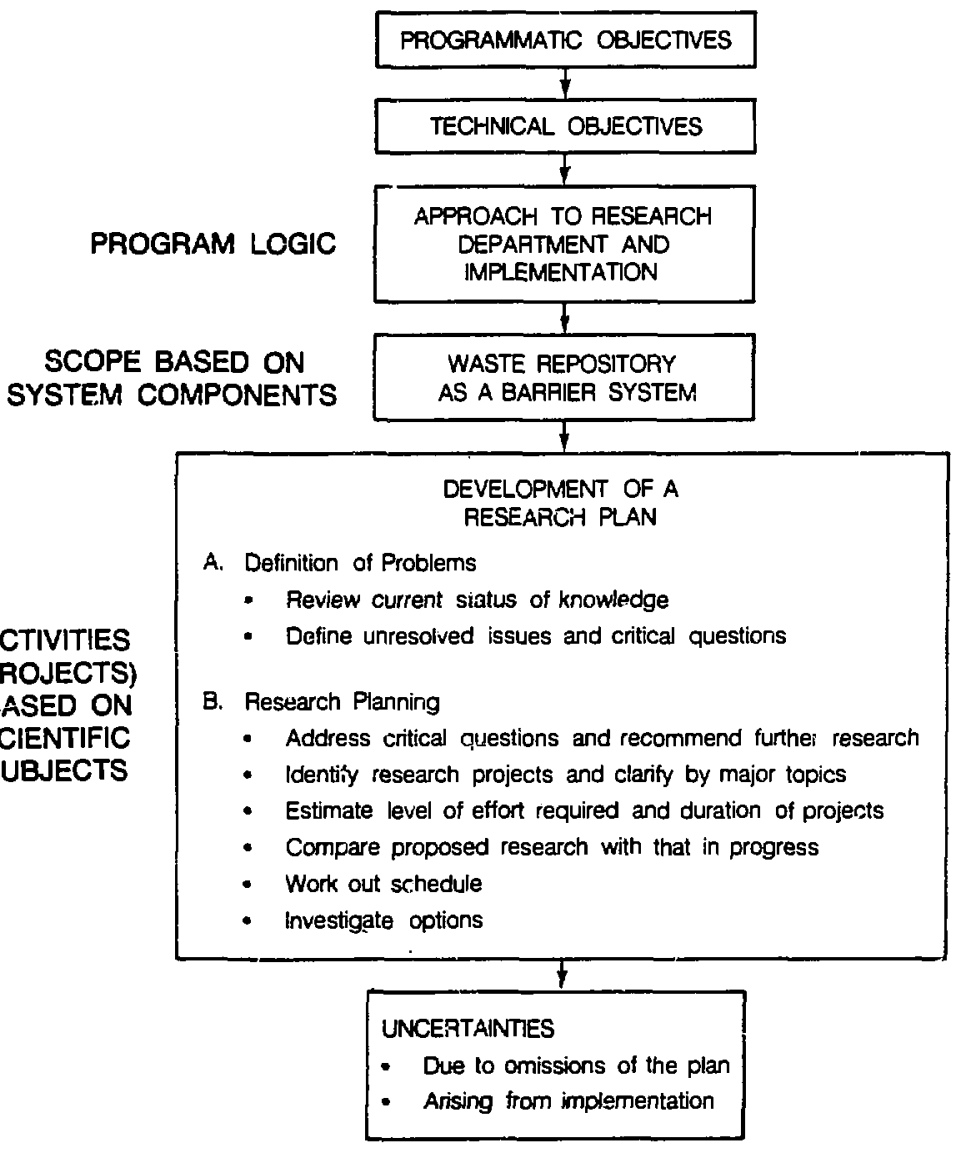

Figure 1.1 Approach to geochemistry research planning for the underground storage of high-level nuclear waste 


\subsection{APPROACH TO GEOCHEMISTRY RESEAPCH PLANNING}

\section{2 .1 Objectives}

The objectives for domestic waste management planning and implementation were defined in the IRG document (Interagency Review Group on Nuclear Waste Management, March 1979, p. 15-18). The prtmary objective is that:

"Existing and future nuclear waste from military and civillan activities (including discarded spent fuel from the once-ti -ough neclear powe? cycle) should be isolated from the blosphere and pose no stgnificant threat to public health and safety."

Addtional technical objectives are that:

- "The selected technical option must meet all relevant radiological protection criterla as well as any other applicable regulatory requirements; although zero release of radionuclides cannot be assured, any potential releases should be within pre-established standards and, beyond that, be reduced to the lowest level practicable.

- "The technology selected for waste disposal, as well as the reasons for its selection, must be well understood, clearly articulated, and widely accentad."

- "The existence of residual technical uncertafnties must be recognized and provided for in the program structure."

These objectives were taken into account in the planning of geochemistry research. The technical objectfve conceraing the residual technfcal uncertainties is very important. Public acceptability of any proposed solution to the isolation of radioactive waste w11l require that the residual technfcal uncertainties be resolved through laboratory and ffeld verffication. It is difficult to provide for public acceptability in the program structure. However, it should be attempted to avold sertous omisstons of sctencific evaluation prior to licensing of a repository.

Public acceptance of uncierg sund waste dfsposal will depend on a successful demonstration of model predictabilfty. Varanini (1979, p. 33) points out that "The real lack of scientific verification, we belfeve, will croate a policy stalemate. Public concern will not be allayed by paper studies and engineerfng excercises in the absence of hard scientific evidence."

Although progress is being made, there is presently no consensus regarding what constitutes sufficient scientific verification. Hence no means of defining the level of certainty that will be needed. (For the approach taken by the U. S. Department of Energy and supforted by a court decision, the reader is referred to U.S. Department of Energy 1980, DOE/NE0007 , Supp. 1, p. 1-6.) In this report no attempt is made to estimace the certainty by which predictions of radionuclide containuent might be wade. 
Yet, there should be ample opportunity to develop a capability to do this while the proposed program is under way. As the program is refined and various acconplishmerts are met, the level of confidence should inprove and a comparacive levei of risk established that could be used as a basis in policy decisions.

A geologic waste repository will probably consist of a system of natural and engineered barriers to radionuclide migration. The dimensions of the barziers, their physical properties, and the thermal and hydrologic conditions pertaining to the repository will define the environment through which radionuclides will migrate. Predicting the migration of radionuclides leached from a breached container: in daenly buried rocks over periods of between $10^{3}$ and $10^{6}$ yrars is without precedent. Comprehension of the chemical processes and the use of mode1s to make quantitative predictions of these processes will be required. Furthermore, the correctness of the models must be demonstrated in the field and laboratory to validate the scientific concepts used in naking the predictions.

Geochemistry research planning should be based on what can be accomplished with existing research techniques, and what in the judgement of the participating scientists constitutes the best means of solving the critical questions requiring resolution. A large amount of research has yet to be done before a satisfactory predictive capability becomes available. This does not mean that problems must be solved beyond all reasonable doibt, only that reasonable quantitative estimates should be made for processes that are presently known only approximately.

\subsubsection{Development of a Logical Approach to Research, Development and Implementation}

Several surveys have been made in the last few years relating to the scientific needs for radioactive waste management (e.g., American Physical Society, 1978; Interagency Review Group, 1979; U.S. Defartment of Energy, 1970; 1979; K1ingsberg and Duguid, 1980;) each reiterating essentially the same general approach with varying levels of detail. Figure 1.2 shows a logical sequence of actions in part suggested by the foregoing authors, to resolve the geochemical problems with the necessary scientific rigor. These steps follcw the classical scientific approach to a complex problem, but recognize the need for technological implementation of the findings, i.e., construction of a repository.

in important difference between this report and earlier approaches is the emphasis placed on geochemical verification through the study of natural systems. While earlier approaches assume complete reliance on short-t:rm field validation of models and trust long-term extrapolations (to $10^{6} y$ ), it is assumed in this report that natural systems involving processes taking place over $10^{2}$ to $10^{7}$ years can be used to provide the needed validation. Computer models describing radionuclide migration can simulate observed natural processes and the two compared as a means of ident ifying errors, omissions or oversimplifications in the models. 


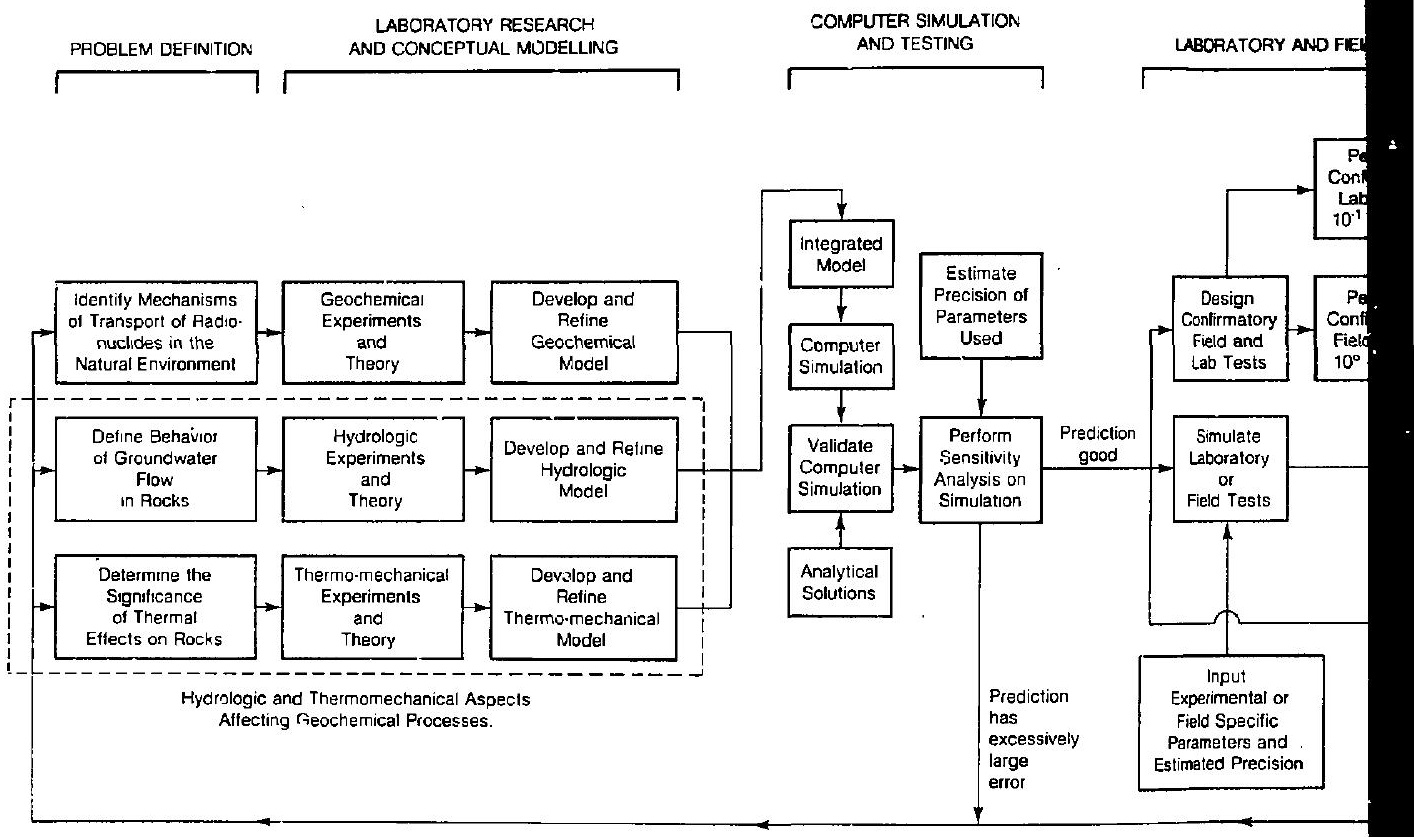

Figure 1.2 Logic chart to identify geochemical needs for th 


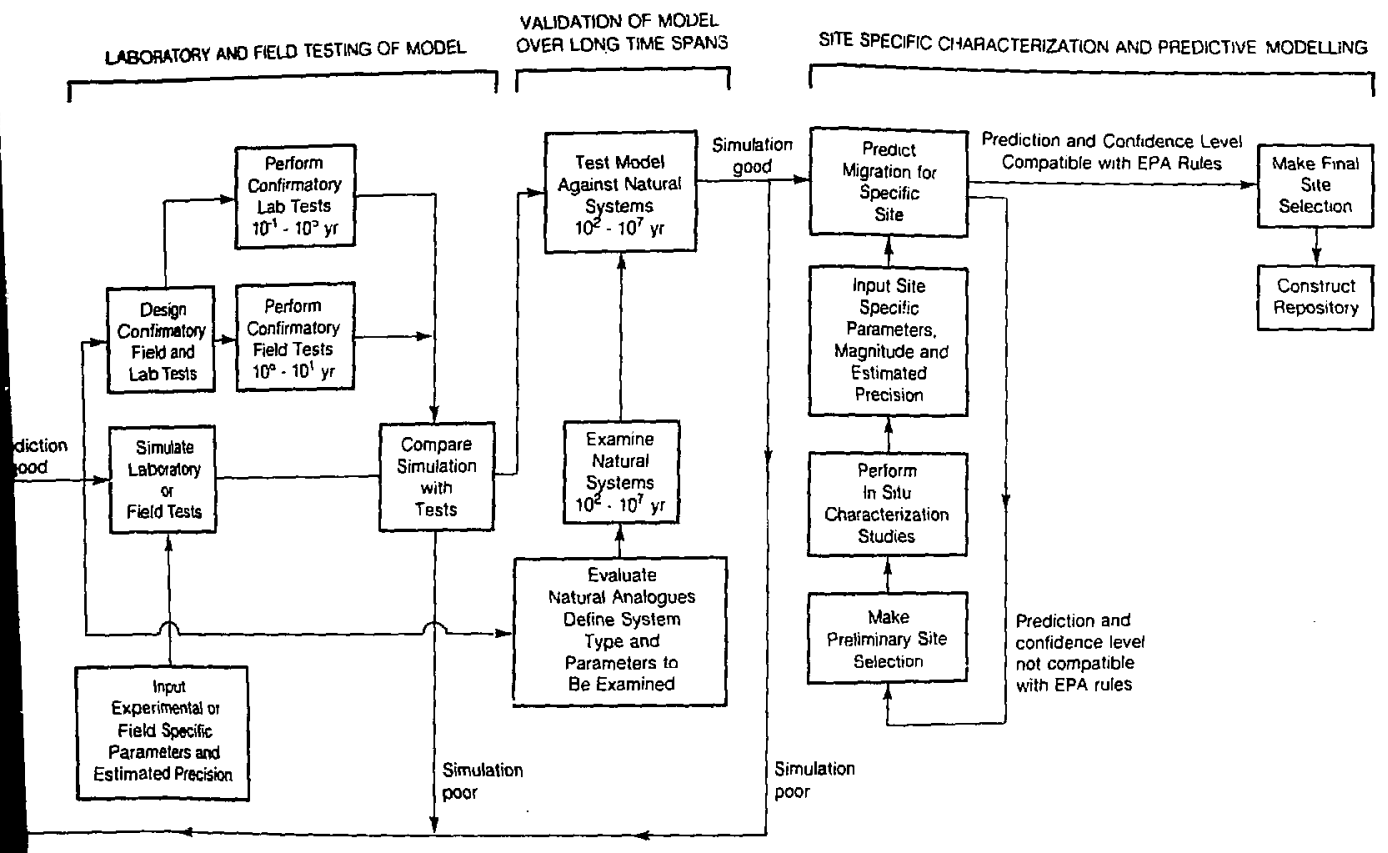

fy geochemical needs for the isolation of high level radioactive waste

XBL 844-9734 
Greater confidence can then be attached to processes covering the time Interval between fleld validation studies (whose duration is rarely greater than 10 years for logistical reasons) and the maximum anticipated isolation time requirenents.

The difficulties inherent in the selection of and evaluation sultable analogues cannot be underestimated, but this is the only course open in ensuring that mathematical modeling can be usefully applied when direct experimen'al verification is impossible.

The normal approach in clartfying scientific or technological issues is to proceed through a logical sequence of actions, 1.e.

(1) Definition of the problem and Identification of objectives.

(2) Interpretation of laboratory experiments or natural phenomena.

(3) Development of a hypothesis explaining the observed phenomena.

(4) Construction of a conceptual model.

(5) Testing of the model through laboratory and field studies.

(6) Elucidation of the processes introduced in the hypothesis and refinement of the model.

(7) Testing of the model on other systems to ensure that it is valid.

For reasons already discussed, this approach is not easy to apply to waste repository design. Nevertheless, it is essential that experimental verification be employed. Varaninl (1979, p. 24) points out, "Not only is it possible that assumptions may be wrong, important natural processes may be overlooked, or parameters may be missing, but also the analyst may have oversimplifled the mathematical framework [of the model]." He further emphasizes "... that repository safety assessments are not predications of what will happen, rather they are predications of what might happen given a set of assumptions and the development of a given sequence of possible or plausible events and processes." To overcome the difficulties, a modified approach is suggested, complementary to that normally used in solving scientific or technical problems. It Includes the following steps:

(1) Definttion of the problem

(2) Laboratory research and conceptual modeling

(3) Development and testing of computer simulations

(4) Laboratory and field testing of radionuclide migration 
(5) Verification of predictive capabllity over long time spans using natural systens

(6) Site selection and characterization

(7) At Depth Testing

(8) Construction

The geochemistry research program plan is based on the assumption that these steps will be followed. Brlef explanatory descriptions are given below.

\section{(1) Definition of the Problem}

This inftial step will, in the context of the geochemical aspects of waste isolation, include consideration of the physical and chemical mechanisms controlling radionuclide transport, and identiffcation of tile information required for hydrological modeling. Experts in geochemistry will determine the most plausible mechanisms and define a program of research establishing the validity of their concepts.

A multiple barrier system wfll be assuned.

(2) Laboratory research and conceptual modeling

This step Implements research designed to ascertain whether postulated geochemfcal transport processes affecting radionurlicie transport ari valid. Conceptual models describing source terms and sorption phenomena wili be formulated. Supporting thermodynamic data, needed to fnterpret experiments, will be obtained from the literature or deterwined experimentally. Owing to the complexity and differing environmental conditions of engineered and natural barriers, different models may be needed to describe conditions peculiar to each barrfer. Engfneered barrlers adfacent to the waste way even require coupled thermomechanical-hydrological-geochemical models to describe their behavior adequately.

\section{(3) Development and testing of computer simulations}

This step will make use of geochemical algorfthms in conputer simulations of englneered and natural barrfer performance. Because almost all computer simulations use numertcal methods for thelr solution, analysical solutions are needed to compare the results of the numerical methods. A computer stmulation can also be a valuable tool in forcing the investigator to recognize the paraweters needed to describe a system adequateiy, in estimating the sensitivity of the output to varfations in these parameters, and in designing experiments both to establish the validity of the nodel and to gain insight in the mechanisms controlling radionuclide transport. 


\section{(4) Laboratory and field testing of radionuclide aigration}

Integrated geochentcal and transport models, once validated, 111 be used to design laboratory and field teats to verify the correctness both of the geochenical algorithns, and the transport nodel(s). Laboratory tests possess the advantage of a controlled environment and convenience of monitoring. However, the possibility cannot be ruled out that such tests do not replicate in-situ conditions. Furthermore, testing in the laboratory is not amenable to experiments where large-s1zed rock samples are needed. Therefore, both laboratory experiments and field tests should be considered, the emphasis depending on objectives and anticipated outcome.

\section{(5) Verification of predictive capability over long time spans}

The only way to verify predictions of radionuclide behavior over very long time spans is to look at natural geological processes replicating as closely as posstble the waste repository conditions. Such natural analogues should be selected with care to permit computer simalations to be reconciled with fleld observations. If major discrepanctes arise, then elther the simulation contains an incorrect formulation of radionuclide transport or the fieid observations have been 1ncorrectly interpreted. Several evaluations of different analogues may be necessary before sufficlent corifldence can be gained in the predictive capaöllity of computer simulations.

\section{(6) Site selection and characterization}

By site characterization is meant all inttal evaluation work performed prifor to and for preparation of tile site characterization report. Characterization is required of the host rocks in both near and far field. All parameters necessary for quantification of radionuclide migration must also be determined, including the antfcipated radionuciide flux leaving the waste package, the magnitude, rate and direction of groundwater flow, and the effective surface area and sorptive properties of the host rock minerals.

The hydrologic and geochemica: propertles of the host rock are inseparable when considering radionuclide migration. The contribution the chomical evolution of groundwater makes in verifying hydrological models, should therefore be considered as well as the effect that waste storage might have on groundwater chemical composttion.

\section{(7) At Depth Testing}

At depth testing will require the sinking of a shaft and construction of an underground facility to access the in situ environment. Tests could include simultaneous measurements of thermomechanical and hydrologic properties and in-situ radionuclide transport in the host rock. Backfill studies to determine the feasibility of replicating optimum radionuclide retardation properties of the backfill and the tendency for it to change 1ts physical and chemical properties over time, or react with the host rock, should also be evaluated under varying thermal gradients. Finally, at depth testing, provides exceptional opportunities for hydrochemfcal characterizations, thereby facili- 
tating the rafinement of hydzological sodels.

\section{(8) Conetruction}

The construction phase will allow for a continuation of activities started during site chacterization and at depth testing, and permit a more Intensive evaluation of near-field conditions. Testing with real waste is a practical possilility at this stage.

\subsubsection{The Vaste Bepository as a Barrier System}

High level radioactive waste disposal has so many institutional, regulatory, sclentific, and technological aspects to it that a systems approach is now considered to be the only way by which the problems may be analysed and approprlate action taken in meeting overall objectives. Uncertainty exists in defining the tierarchy of subsystems involved and their interactions. Although it is entirely beyond the scope of this report to analyze this hierarchy, the reader should be aware of its existence and the impact it has on geochemistry research planning.

The U. S. Department of Energy's Natłonal Waste Terminal Storage Program uses a systems approach with the goal of permanently containing radioactive waste in a geologic repository. The geologic repository itself is a subsystem composed of natural and engineered barriers. Each barrier is designed to fulfill a specific function or functions, among which is preventing or retarding the release of radionuclides to the accessible envirorment. The behavior of each barrier is dependent on its thermomechanical, hydrologic, and chemical properties. However, the predicted ralease of radionuclides from the barrier system will depend on the interactive behavior of all barriers. The barriers normally recognized are:
(1) Waste form
(2) Canister
(3) Overpack
(4) Backfill
(5) Near field and far field

The first three of these barrlers constitute the waste package and are not addressed in this report. Of the remainder, the backfill constitutes an engineered barrier, whereas the near and far flelds consist of natural barriers comprising the host rock in which the repository is constructed. The near field is separated from the far fleld, possibly somewhat arbitrarily, in that the former occupies a volume of rock which is affected by the emplacement of the waste, efther mechanically (by rock breakage), thermally (by heat generated by the waste), or chemically (by grouts or other chemically reactive constituents used to modify the host rock in expectation of enhancing radionuclide containment). 
The ystea of engineered and natural barriers siould be designed to meet at criteria governing radionuclide relense into the accessible enviropent. Given this rewtraint, the barrier systen design ny allow eagineering ingenufty to meet the overall requirenents. The dinensions of engineered barriers, however, are largely constrained by conventional mining technology.

The barrier system capacity may vary depending on site location, host rock type and cholce of waste form. In some cases, additional engineering barriers may needlessly complicate performance predictability, or provide no increase in environmental protection while substantialiy increasing the cost of waste disposal (Clafborne, 1982) however, standard engineering practice has rarely if ever been applied to problems such as those encountered In repository design, and operational uncertafnties over the long time periods required for isolation may require an extraordinary level of redundancy to ensure public acceptance.

Appendix A, "The Geologic Repository as a Barrier System," defines a representative barrier system, and its subsystems and components. Also included are the parameter 3 affecting radionuclide migration, technical questions needing resolution, and relevant regulations, tecinical rules and defintions from 10 CFR Part 60 pertaining to the geochemical aspects of the barrier system. The technical questions are the basis for the reviews incorporated in Apps et al., (1982), as described in the following section.

\subsection{DEVELOPMENT OF A GEOCHEMISTRY RESEARCH PLAN}

Geochemistry research planning first and foremost must lead to the implementation of a zeochemistry research program that will demonstrate that high-level radioactive raste can be isolated from the accessible envirorment while meeting NRC techanical rules and EPA standards. Secondly, it must be subject to the realistic restraints of manpower, facilitits, and budgets. Finally, it should be responsive to time schedules for licensing and construction of an underground repository. Research plans directed towards specific goals should also consider alternative strategies in case a given course of action falls. Uncertainties in meeting goals mean that estimates of required sudgets, manpower and time will be somewhat nebslous. Nevertheless, some kind of plan is better than none at all, and even if imperfect, will serve to channel research and development effcrts more effectively. Furthermore, it may also serve to refine NRC technical rules.

\subsubsection{Steps involved in developtng the plan}

The overall approach to developing a plan for the resulution of geochem1stry research problems Involves a sequence of steps: Steps 1 though 4 are given in Apps et al, (1982). Part of step 3 and steps 4 though 9 are given in Cnapter 2 of this report. The steps are:

(1) Review the current status regarding the chemical aspects of subsurface waste isolation. 
$A$ witiplc-barrier syseren consisting of both engineered and natural bartiers as discussed $1 \mathrm{a}$ the preceding section is asumed to be the eventual configuration of the repository. The host rock will be selected fron those currently considered to be nost plausible, l.e., donal and bedded salt, basalt, tuff, granite, and shale. The review process is accomplished by assessing the current status of knowledge through a reading of the current literature and evaluation of research underway by DOE and others.

\section{(2) Identify technical questions.}

Through (1) above, wajor techalcal questions are identified requiring resolution. The technical questions are classified according to their relationship to the barrier system, as illustrated in Appendix A.

(3) Address and resolve the technical questions or recommend further research.

The underlying problem is surveyed and evaluated, and an effort is made to 80 as far as possible in attempting to resolve the questions through preliminary calculations and estimates. Conclusions are drawn from the evaluations and appropriate recommendations are made.

This phase of the planning effort involved Individual evaluations by professtonal staff members in the Geochemistry Group at the Lawrence Berkeley Laboratory. Their evaluations are presented separately in Apps et al., 1982 . Not all questions posed were addressed because the number of questions was greater than could be accommodated with avallable funds and the diversity and expertise required to answer all questions was not available. The findings, conclusions, and recommendations of the scientific staff are given in Apps et al., 1982.

(4) Identify spectfic research projects emerging from the recommendations and assign priorities. Classify research by wajor topics.

Although the critical questions posed were based on the system of engineered and natural barriers surrounding the burfed radioactive waste, it was found that the recommendations showed suistantial overlap or addressed problem areas that had broader 1mplications than the narrower focus of the critical questions upon which the recommendacions were based. Therefore, the projects emerging from the recommendations were grouped according to seven major topics:

- Bounding conditions

- Transported forms

- Transport mechanisms

- Retardation mechanisms

- Physical/chemical properties of barriers 
- Checteal tzansport algorithes

- Field evaluations.

Th1s structure has two advantages: Firec, it avolds repetition of sinilar toplcs for different barriers; secondly, it allows for a generally sequencial flow of information to the final stage of research ebtablishing the feasibility of the storage of underground radioactive waste. The resesch projects are listed in Chapter 2 of this report and In Apps et al., 1982.

(5) Estinate the level of effort required and duration of each research project.

Very approxinate estimates were made of the levels of effort expected and duration required for each project. These estimates were based on the scientific judgement of qualified staff with experlence gained in similar research, and reasonable assumptions regarding the staff required and the level of education and experience needed to accomplish the project. More detailed estimates could not be made without scoping of individual projects; a task that would be neither productive nor appropriate at this stage of planning.

(6) Compare proposed research with that currently in progress by DOE, NRC, and elsewhere.

This was accomplished by compiling a list of all projects known to be funded as of fiscal year 1981 .

(7) Identify precursor and successor projects.

Projects that must be accomplished before other projects can be completed should be identified and their relationship to futhe projects determined. "

(8) Work out schedules.

This phase of che planning was undertaken using CFMG, a computer code developed at the Lawrence Berkeley Laboratory to facilitate the planning and organization of complex projects. Milestones were established and resource requirements determined.

(9) Consider issues that cannot be resolved in the time frame permitted and uncertainties in the program plan.

The final stage of program planning deals with the problems arising from the need to recoricile the idealized research needs with the practicality of limited budgets, manpower availability, and the technical and time restraints of the real world. 


\subsubsection{Level of Regearch Investigation Required to Satisfy}

\section{Requlatory Requirenents}

Research, by its very nature, involves uncertainty. Therefore, any estInates of the level of research needed to resolve the waste isolation issue nust necessarily be imprectse. However, a number of restraints can be placed on the research so that the effort expended will be directed towards resolving issues productively, efflciently, and within the time limits imposed.

First, complete resolution of all aspects of a problem is not required but only those sufficfent to allow a prudent sscientist to proceed with conf1dence to the next stage of an 1nvestigation. This approach can be more costeffective and time-efficlent than traditional research techniques but also involves a greater risk of error.

Secondly, it may not be necessary to perform any research on some topics because calculations would show that their impact on the final outcome would be negligible. A nalve example of this would be the study of strontium-90 migration. Strontium -90 would have decayed to infinitessimal concentrations after 1000 years of storage, or if it were to be released from a canister Immediately after burial, would never find its way to the accessible environment before complete decay (Wood, 1980). This restriction on the level of research should also be tempered by exceptions knom to-occur in all research activities. For example, investigation of strontium-90 migration may the basis for elucidating transport mechanisms of a radionuclide such as radium-226, or a relatively innocuous radionuclide may be part of a chafn of daughter prodicts, one of which could be quite toxic. Thus the migration behavior of the whole chain might have to be studied.

Another factor affecting the research effort is that not all research needs can be Identiffed a prior1. To find out whether previously unidentified research needs exist, it is someilmes necessary to proceed with efther insufficlent or nonexistent input, using only reasonable estimates or suppositions to get to the point where further research needs become apparent.

The iesearch effort can be limited by restricting the environmental conditlons under which waste is stored. This has been covered in Chapter 2 of Apps et al. (1982). In addition, relaxation of environmental standards, specification of a lower maximum temperature, a mandatory 1000-year confinement of radionuclides to the canister or limitation of the number of engineered barriers, all decrease research needs. However, these must be balanced against the possibility of increased risk or uncertainties. 


\subsection{RECOLENDATIONS FOR DEALING WITH UNCERTAINTIES.}

This topic, which is the subject of Chapter 3, covers two major areas of uncertainty and recomendations to resolve then; (a) technical oulssions of the plen, and (b) uncertainties arising from implementation of the plan.

\subsubsection{Technical Omiseions of the Plan}

Nine issues not examined in the course of development of the plan are discussed. They are:

(1) Natural analogues

(2) Radiolysis

(3) Design of laboratory and field experiments

(4) Radionuclide getters

(5) Effect of differing host rocks on radionuclide containment

(6) Borehole plugging wacerlal interactions with host rock

(7) Transuranic element daughters

(8) Radionuclide adsorption on mineral substrates

(9) Development of geochemical field monitors.

These issues may have an important bearing on the geochemistry research program, but they must first be evaluated.

1.4.2 Uncertainties Arising fron Implementation of the Plan .

Under this topic, the following issues are considered:

(1) Implementation

(2) Manpower

(3) Costs

(4) Organization

(5) Timing of projects within the program

(6) Interfacing with other programs.

All these issues can be addressed with further refinement of the present plan. 


\section{RECOIMENDED RESEARCH PLAN}

\subsection{INTRODUCTION}

The recomended research plan in geochealstry, presented in this chapter, has evolved from the recomendations made by sclentists in the process of reviewing a series of critlcal questions given in Apps et al. (1982). The coverage is not complete because the availability of staff and resources were unequal to the magnitude of the task. Nevertheless, it is belleved that the wost important issues have been covered and few major topics remain uninvestigated. The plan Incorporates all aspects of research Including theory, modelIng, and both laboratory and fleld experfmentation. The conventional approach discussed in Chapter 1 has been taken, 1.e., from problem definttion through laboratory and fleld testing.

This chapter is divided into four sections in addition to the introduction. The first identifies key research needs. The second compares these needs with ongoing research, and the third discusses the schedule of the plan. In the final section, varlous options and issues are discussed.

\subsection{KEY RESEARCH NEEDS}

Key research needs were identified through a multistep process using the recommendations of Apps et al., (1982). The recommendations are as summarized in Table 2.1. The table includes assignment of priorities to the recomendations and the action taken with respect to each recommendation. These are discussed further beiow.

\subsubsection{Priorities}

Five levels of priority are assigned to the recommendations from Chapters 2.0 and 3.0 of Apps et al., (1982). They are as follows:

(1) Leads to research of the highest priority in the area cif peochemlst:y. A problem probably requiring resolution before radioact e waste can be stored underground.

(2) Leads to research of second priurity. May be essential that it be completed before storing waste underground at a given site.

(3) Would, if implenented, provide valuable supporting information, increasing the credibility of underground waste disposal.

(4) Neither essential nore critical to the emplacement of radioactive waste but may, if implemented, facilitate more rapid resolution of existing uncertainties.

(5) Restricts scope of proposed research or require no further acrion.

Most recommendatlons given in Table 2.1 either lead logically to further geochenlstry research or place bounds on the extent of such research. 


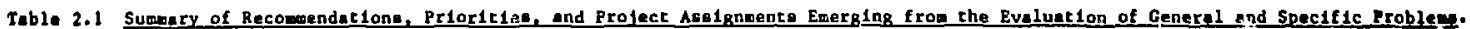

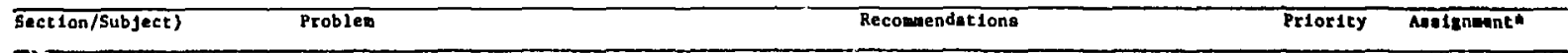

\begin{tabular}{|c|c|}
\hline $\begin{array}{l}2.2 .1 \text { sounding } \\
\text { the physical and } \\
\text { chealcel } \\
\text { cond } t \text { t lone }\end{array}$ & 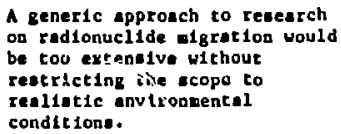 \\
\hline
\end{tabular}

2.2.1 Dounding A generic approsch to research the phyalcal and on radionuclide algration vould chesice 1 conditione.
1. The effact of preanue between 1 and 500 bere on the compaction of backfil aaterials and the relation of this to porastcy, permeabilicy, and radisnuclida migration hould be laveut1gated.

2. Long-term change in chenical and phyoleal properciea of backf1ll and host rocks inould be lovest1gated at temperstures to $300^{\circ} \mathrm{C}$.

3. Radionuclide sorption and complexation should be studied on a restricted suite of rad'anuclides to $175^{\circ} \mathrm{C}$.

4. Radionuclide sorption scusies ahould be reat icted to clay minerole, 1ion oxides, alcas, one or tw: commonly occurring zeolites, feldspars, and Bli: ca.

5. The algrificance of selecced ainerals on spe itic radionuclides ahe'uld is evaluated, a.g., the ac.ption of trivalent actinides on apaite should i.e Investigated.

6. A satisfactory means of characterizing aurface area in relation to radionuclide sorption should he Inveat 1 gated.

7. The fundanental relationahlp becween radionuclide iorption mechanisms . nnd surface i.rea nhould be Invest 1 gated.

8. Groundwacer esmpling procedurea should be devaloped to allow for t.contamina: = i ampie procurement.
A Project 5.2

B Projece 1.1

A Lieit ecope of tudioe on radionuclide behevior to $175^{\circ} \mathrm{C}$

I Limit winaral abbetrates in etudias

D above

C Project 5.6

D Projecte 4.1

B Profecte 1.2, 7.8 
Taibe 2.1 (cont.)

\begin{tabular}{|c|c|c|c|c|}
\hline Section/SubJect) & Problex & Re compendat Iona & Priority & Antencant: \\
\hline \multirow[t]{2}{*}{$\begin{array}{l}2.2 .2 \text { Toxic } \\
\text { radionuclide in } \\
\text { opont reactor } \\
\text { fuel af cer } \\
1,000 \text { years }\end{array}$} & $\begin{array}{l}\text { it Is not clear uhich radionuclides } \\
\text { are mast toxic and which ones ghould } \\
\text { oe investlgated with respect to their } \\
\text { migration through reposicory } \\
\text { barriera. }\end{array}$ & 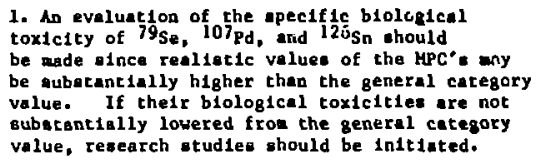 & $\boldsymbol{A}$ & 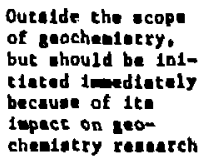 \\
\hline &. & 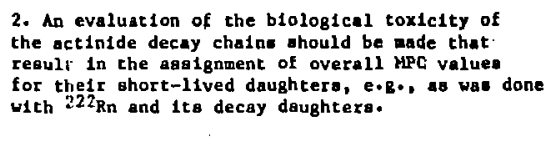 & $\mathbf{P}$ & 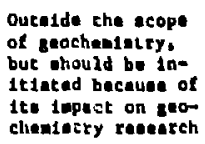 \\
\hline
\end{tabular}

$\begin{array}{ll}2.3 .1 \text { Inorganic Data avallability, espectally } \\ \text { complexarion } & \text { at elevated temperatures, and }\end{array}$

modeling wixed electrolyte

behavior ac high lontc

strengths are deficiencies

hindering progress in radio-

nuclide cranspore calculatiana.

Calculations lacking essential

dats on complexing will tend

to overestimste retsrdection

, due to sorpcion and prectpitation.

In Apis et al., 1982

MProjecis ere described in numertcal order In Table 2.2.

1. A consenaus to needed with regard co hazard A Ste Socton 2.2 .2

ranking of toxic radionuclides.

2. Pormation conotants of complexes of radionuclides wth common groundwater $11_{\mathrm{Bands}} \mathrm{(OH}^{-}, \mathrm{Cl}^{-}, \mathrm{HCO}_{3}^{-}$. $\left.\mathrm{CO}_{3}{ }^{2-}, \mathrm{SO}_{4}{ }^{2-}, \mathrm{F}^{-}\right)$should be obcalned.

3. Pormation constants of the most Important complexes should be deterained over the range $25-175^{\circ} \mathrm{C}$.

4. Improved methoda for correlating and predicting stability constante should be developed, Including the effects of tempersture. Data should be appiled to model chemical Interactions and transport of radionuclides.
Lintt acope of projecte 2.1 , 2.3.

A above

B Output of projecte 2.1.2.3 10 input for 6,2 and 6,5 
Toble 2.1 (cont.)

\begin{tabular}{|c|c|c|c|c|}
\hline sect1on/Subject) & Probled & Recomendations & Priority & Aselgnent \\
\hline $\begin{array}{l}2.3 .2 \text { Organie } \\
\text { conplexation }\end{array}$ & $\begin{array}{l}\text { Organic complexing with pecal } \\
\text { liganda in groundwater any } \\
\text { be igniflcant and could affect } \\
\text { radionuclide } k_{d} \text { 's and } \\
\text { migration behavior. }\end{array}$ & 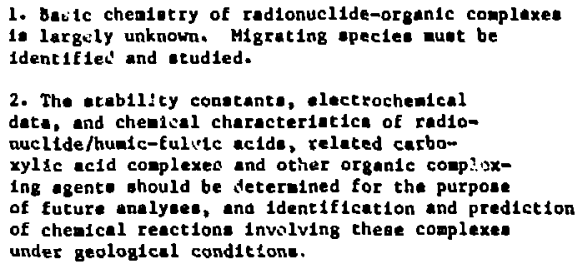 & $\mathbf{1}$ & $\begin{array}{l}\text { Projecte } 2.3,7.1 \\
\text { Profect } 2.6\end{array}$ \\
\hline & & $\begin{array}{l}\text { 3. Interactions of radionuclide-organic complexea } \\
\text { uth mineral ourfaces ohould be ocudled with reapect } \\
\text { to organic ligand content at apecific altes. }\end{array}$ & D & Project 4.3 \\
\hline
\end{tabular}

2.3.3 Collo1d There is aple evidence for the
and perctculate trunaport formetou of colloldace for che pended parciculates in groundwatera. Both peeudocolloide end true collotde could form, but little Infor uction about conditiona of formation, longterv etabilicy, or potential for migration 1o avaliable. Their ignificance ahould be catablished.
1. The neture, propertien, and redionuclide content of colloldal forme produced through degradation of high-level uasteg should be determined.

2. At temptr should be made in the laboratory to produce true colloldal forms of insoluble epeciea of the 1mportant waste radionuclidee under condi tione anticipated for the groundwatere at a proposed otorage aite, If there to on indication of true collold formation, research should be extended to study the conditione for the formation, wbility, and algration behavior of the collolda.

3. Concentrations, particle-aize diatribution, and wigration properties of colloldal material supended in underground waters should be measured, especially in basalt, tuff, and grentte.

4. The mineralogy and chemistry of particulate matter in deep aquifere at specific altes ghould be inveatigated.

5. Sumpling methods free of containination from guspended particulacea due to drilling should be developed.

c

Project 2.7

Project 2.8

Project 7.2 


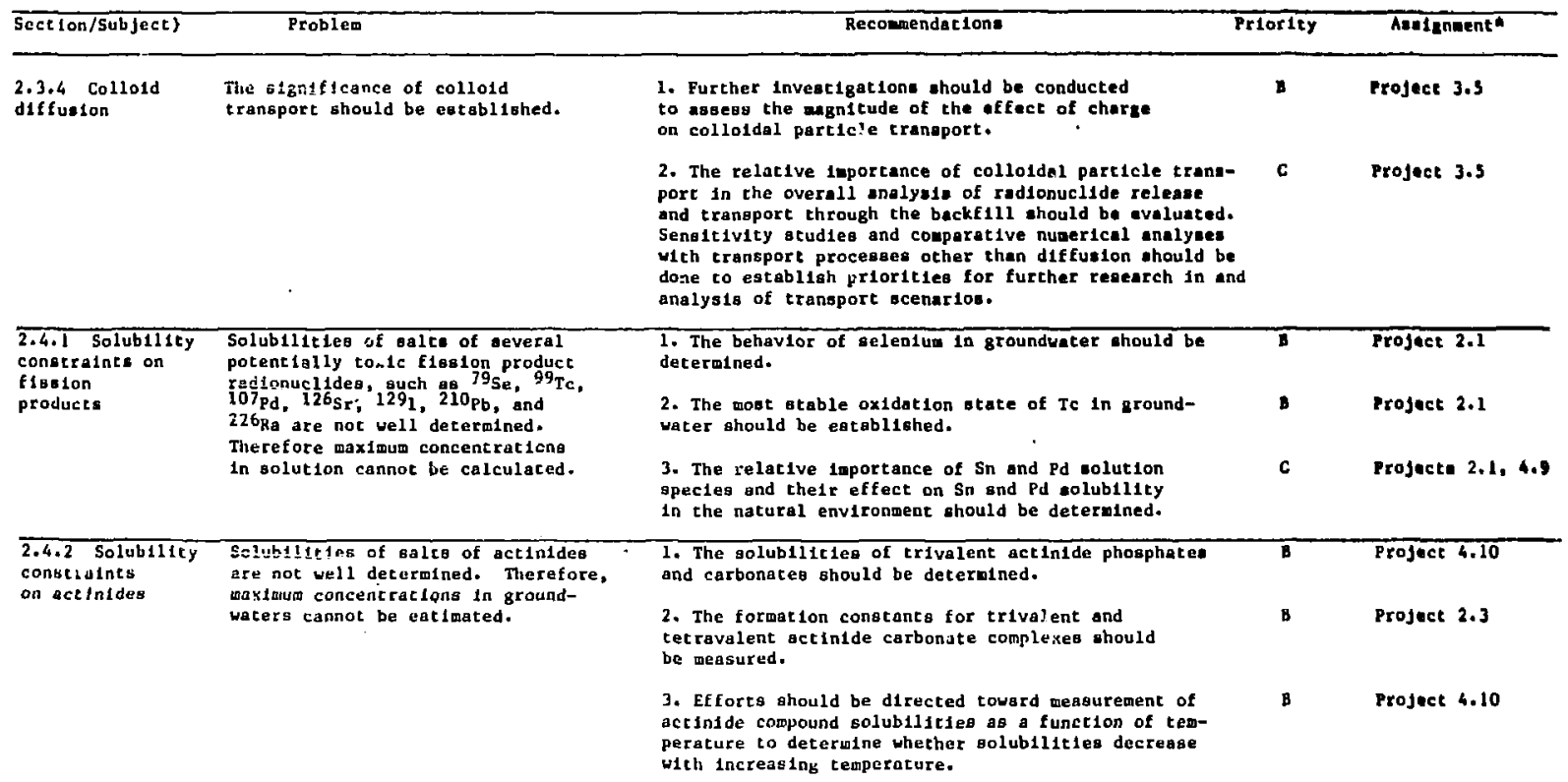




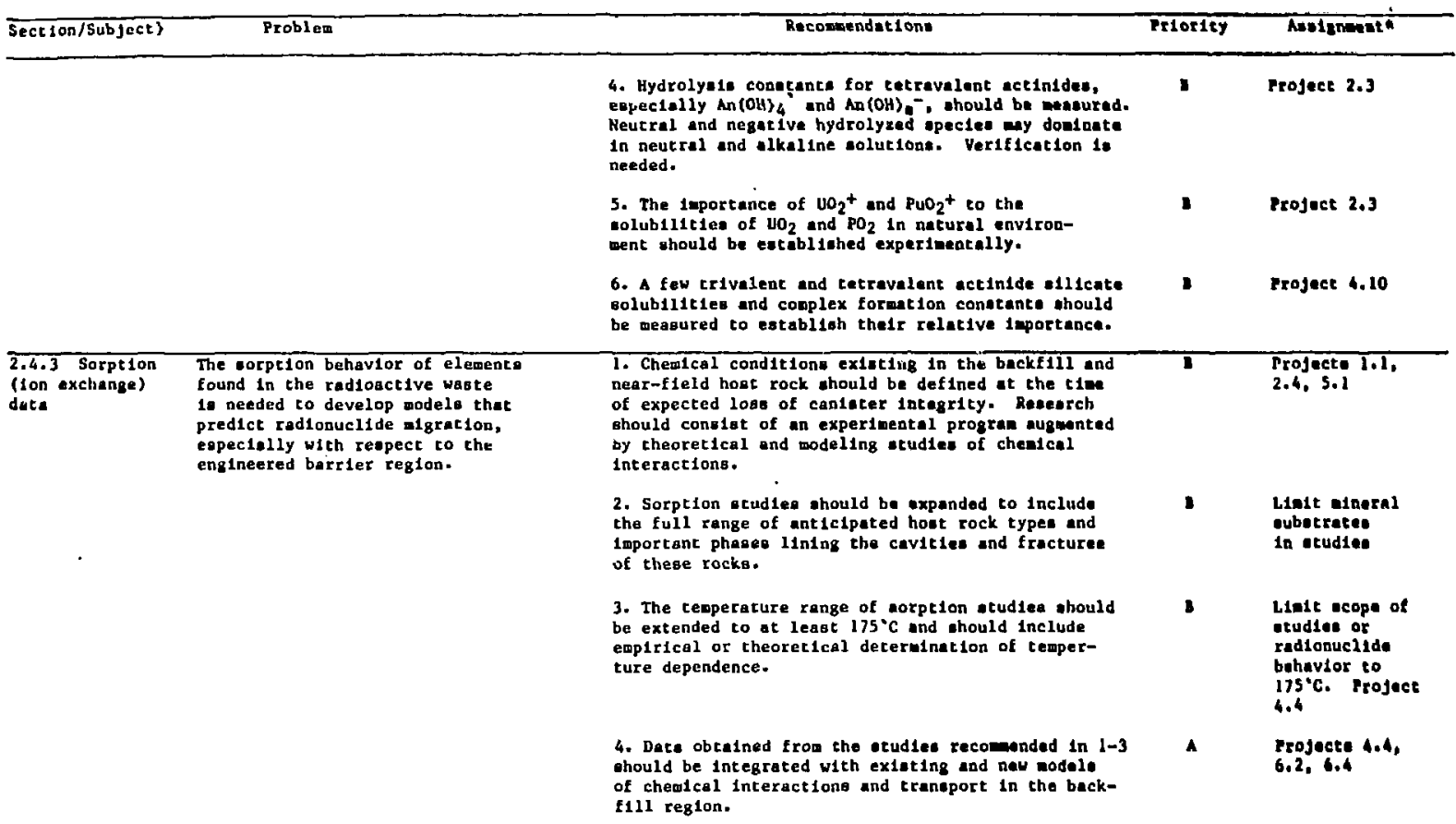




\begin{tabular}{|c|c|}
\hline Sect Ion/Subject) & Prablex \\
\hline $\begin{array}{l}2.4 .4 \text { Ef lects of } \\
\text { long-tero nonequt- } \\
\text { llbrium vacer- } \\
\text { rock interact tons } \\
\text { on radionuclide } \\
\text { recardation }\end{array}$ & $\begin{array}{l}\text { Hany reactions between radio- } \\
\text { nuclides and host rocks nay } \\
\text { not be readily observable in } \\
\text { ohort-duration laboratory } \\
\text { experimente, but may } \\
\text { dominate transport processes } \\
\text { In sicu. }\end{array}$ \\
\hline
\end{tabular}

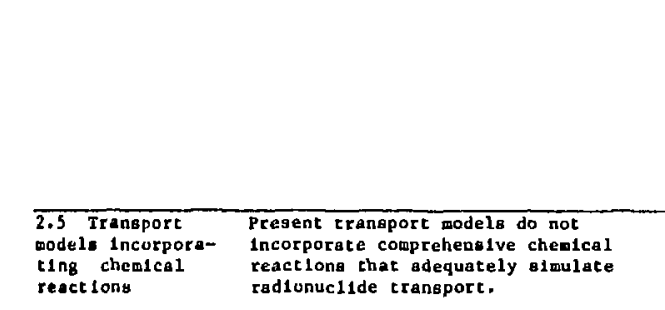

1. A leboratory and theorecteal progran should be
coilducted to determlne the effect of long-tern nonequilibri
retardation.

2. State-of-the-art ourface analyticel techniques should be used to quancify slou diffusion rates over experimentally realiotic time periods at repository cemperacures.

3. A mechanistec model should be formulated to extrapolate to long-term condicions. Confiratory in oitu field teots should be carried out.

4. The chentstry and mineralogy of otte upecific
1. A laboratory and theorecical progras ahould aquifer curfaces of near- and farmfleld host rocke should be characrerized in detail.

\begin{tabular}{|c|c|}
\hline Frlortty & Alotgnent \\
\hline $\bar{A}$ & $\begin{array}{l}\text { Projecte } 4.5, \\
4.6\end{array}$ \\
\hline$A$ & $\begin{array}{l}\text { Profecte } 4.7 \text {, } \\
4.8\end{array}$ \\
\hline
\end{tabular}

1. The levelo of sophistication required of chealcal
algorithus describing radionuclide transport pust be algorithous describing radlonuclide transport muct be
addressed, especially wich respect to complex chealcal reactions in the near field.

2. An adequate creatment of precipitation. Including reversible disgociation, must be Incorporated in radionuclide transport modela.

3. Trangport models should be validated using dynanic colum experimente if such tranaport processea are deemed necessary to the understanding of radionuclide rigration.
$\boldsymbol{A}$ Projecte 4.10, 7.13

$A$

Project 7.7
$\mathbf{A}$

Project 6.5

$\mathbf{A}$ Projecte 6.1 .
6.5

A Project 6.14

\begin{abstract}
3.2.1. Low yerwe- Permeabllitles and porositiea of abllity lack- backfill materislo may drastically fll materiala affect the degree of containdent of radionucildes.
\end{abstract}

1. The hydraulic conductivity and porosity of opecific backl111 materialo as a function of compaction presoure and chemical saturation atate should be defined experimentaliy.

2. Betcer estimaces of releted parametera should be defined for actual repository conditions; e.8., hydreulic gradieats ohould include site spectfic temporal variations in hydraulic, thermal, and chemical potential fradtents. Diffusivities of specific radionuclides should be measured in clays as a function of compacion pressure and eleccrolyce concentration. 
Table 2.1 (cont.)

\begin{tabular}{|c|c|}
\hline Sect Ion/Subject & Problem \\
\hline $\begin{array}{l}3.2+2 \text { Diffusional } \\
\text { erunsport of } \\
\text { radionuclides } \\
\text { chrough a } \\
\text { nongorbing } \\
\text { batrler }\end{array}$ & $\begin{array}{l}\text { In order to estimate the extent } \\
\text { co which radionuclides vould be } \\
\text { contained in che backfill, che } \\
\text { limling case of a nonsorbing } \\
\text { barrier in spherical gcometry } \\
\text { must be conoldered firuc. }\end{array}$ \\
\hline
\end{tabular}

1. The source tera must be defined. Data should be

acquiced on dissolution rutes of wate fore, denree of congruity of dicsolution, Identities of posible colid secondary phases formed in the cource region, and Ident1t1es and concentration of eoluce specles produced in dissolution or in equilibriue vith secondary phanee.

2. Transport propertlea pertalning to englneered barriers aust be measured, 1.e., diffusion coefficienta of solute apecieg and tortuosities. If convective tranoport is also included, eecinates of barrier diepersivitieo, porosic1es, and permeabilitien are required.

3. Hodeling of traneporc procenaes through aultiple layered media ahould be undertaken.

riority Malgrient

Projects 4.9. 4.10

4. Further Investigetion should be nade of traisport modeling in the temporal doman following dieapperance of the source term, 1.e., complete dissolution of the waste form and solid.

5. Transport wodeling should be extended to array" of waste canisters eurrounded by barrier materiale.

6. Cross-diffustongl coupling and coupling of mas fluxes to thermal fluxes should recelve nore

attencion.

\subsubsection{Transport}

of radionuclide

clirough the back-

III WIth

uorption
Est1anates are needed of barrier ef ect iveness in retarding radio nuclides oo that barrier

function may be better defined and opt Lmized and the problem of far-field containment be bet ter defined.
1. Hore realiatlc models are needed to auses the effectiveness of engineered barriers in reducing the rate of radionuclide of gration. Such models ahould incorporate realistic boundary conditiona and modeling of the host-rock environment. Fractured medis ahould be considered. The cheolical interactions included should adequately predict wig-ation rates.

2. Acceptability criceria ghould be developed that do not depend on blosphere dllution. A blosphere relevance factor should be def Ined and compuced for tach repository.
Project 6.12

Project 6.7

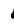

Froject 1.1, 3.2, 7.12

Project 6.12

Project 6.13

$\mathbf{A}$

Projecte 6.1.

$6.5,6.12$, 6.13

A

Oute 1do scope of gnocherist ry rugercl 


\begin{tabular}{|c|c|c|c|}
\hline Stection/Subject\} & Probletu & Hecompendat I ons & Aluelanent \\
\hline \multirow[t]{2}{*}{$\begin{array}{l}3.2 .4 \text { criticality } \\
\text { potential in a } \\
\text { repository }\end{array}$} & $\begin{array}{l}\text { Figalle lotopes may be redis- } \\
\text { tributed in a geclogic repositary } \\
\text { and become critical. }\end{array}$ & 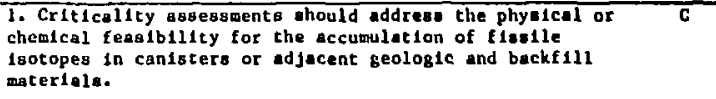 & Project 6.15 \\
\hline & & $\begin{array}{l}\text { 2. Assessmente made under } 1 \text { liould be compared with } \\
\text { analogous natural syutems. }\end{array}$ & $\begin{array}{l}\text { Out olde ecope } \\
\text { of present } \\
\text { oveluetion }\end{array}$ \\
\hline $\begin{array}{l}\text { 3.3.1 Ef fect of } \\
\text { wate emplacement } \\
\text { on the near-t teld } \\
\text { onvironwent }\end{array}$ & $\begin{array}{l}\text { Phase changes in rocks caubed } \\
\text { by radioactive heating could } \\
\text { cauge unanticlpated effects on } \\
\text { radionuclide migration. }\end{array}$ & $\begin{array}{l}\text { 1. Further evaluation should be made of post-repositoty- } \\
\text { closure response of host rocks co reenturation, theresi } \\
\text { st resses, Intrubion of backf111, and beckf111 overpreseures. }\end{array}$ & $\begin{array}{l}\text { Outaide ucope } \\
\text { of grochentutry } \\
\text { reanereh }\end{array}$ \\
\hline
\end{tabular}

2. Introduction of oxygen scavengers in backfill ahould be considered, particularly in granicic, rhyolitic, cuffaceous, or oxidized bedimentary terranes where ferrous ion concentrations in host-rock olnerald se very lou.

\section{The trangtent generation of ateam pocket adjacent to the uaste caniater should be invest1gated for} chemlcal and phyolcal changes that would adversely affect radionuclide contalnment.

\section{Spalling and chimey formation resulting fros} compsction of poorly conoplidated backfill hould be Investigated and the consequences of increased grounduater circulation established.

5. Alteration of basalta and granitea under hydrothermal condiriong expected in a repository should be reviewed in greater depth and expected eecondary minerals predicted for given bulk chenlcal composit lons.

6. The mechan 1sw of fracture oealing by secondary minerals in shales should be examined more thoroughly and techniques developed to ensure such mechantowe might operace fin che near field of a repository.

7. Further review and research 18 required to understand the effects of near-field aineral alteration and geomechanlcal changes on radionuclide transport.
8

Frajects 3.4.

\section{$5.5,7.15$}

c

Project 1.9

\footnotetext{
In Apps et al. 1982

*Prujects are described in numerical order In Table 2.2 .
} 
Table 2.1 (Cont'd)

\begin{tabular}{|c|c|c|c|c|}
\hline Section/Subject) & Problem & Recommendations & Priority & Alorgneant \\
\hline $\begin{array}{l}\text { 3.3.2 Effects of } \\
\text { temperature } \\
\text { gradients on } \\
\text { permeability }\end{array}$ & $\begin{array}{l}\text { It } 16 \text { nat known how the near- } \\
\text { f leld host rock will reapond } \\
\text { chemicaily ro thermal gradients. }\end{array}$ & $\begin{array}{l}\text { 1. Further research on this mbject ahould be poit- } \\
\text { poned until the detailed thermal history of a } \\
\text { repository can be calculated. }\end{array}$ & I & Project 7.11 \\
\hline $\begin{array}{l}\text { in the near- } \\
\text { fleld zegion }\end{array}$ & - & 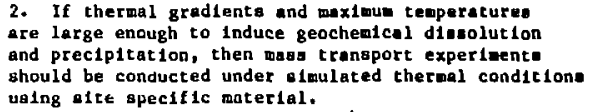 & $\boldsymbol{B}$ & $\begin{array}{l}\text { Propiecte } 2.2 \text {, } \\
7.9\end{array}$ \\
\hline
\end{tabular}

3.4 Groundwater Soma mans of est lmating

dating the age of groundwaters is

needed to reconctle hydro-

logical predictong hy

logical predict lons in the far-field.
1. Grounduater dating techniques should be applied

as a site evaluation method, using an many techniques

as possible. Studies should be conducted to decervine

whether changes in groundwater chemistry w11 affect

age measurements.

2. Research should continue on the multiple application af eeveral dating techniques to get betcer evidence of the applicabilicy of each technique.

\section{Hore attention sliould be paid to grounduater}

oampling methods and the bize of ouple cealistically

recoverable yet at1ll representative. Sampling qualicy auat

be adequate for the most engifive method.

4. A neu emphasia needa to be placed on research uning water dating techniques to detect low-volume but high-

velocity paths through an otherwloe blow-moving ground-

water gystem.
Project 7.5

Project 7.4

Project 7.1

Froject 7.6

\section{In Apps et al., 1982}

Projects are described in numerical order in Table 2.2. 


\subsubsection{Clestification}

Recomendations are broadly classified into seven elenenta, each elenent representing a stage in the evaluation process to clarify the geocheaical problens.

\section{These elements are:}

1. Bounding conditions

2. Transported forms

3. Transport mechantsms

4. Retardation mechanisms

5. Physical/chemical properties of barriers

6. Chemfcal transport algortthms

7. Fleld evaluations

Element 1, Bounding Conditions, contains recommendations that serve largely to define the scope of research needs specifled in the remaining six elements. Elements 2, 3 and 4 are directly concerned with recommendations relating to radionuclide transport and to clarification of the mechanisms involved. Element 5 contains recommendations having a bearing on the interrelationship of geochemical processes with the physical nature of the barrier system. Recommendations are here aimed at resolving issues requiring classification before chemical transport algorithms can be usefully employed in predictive modelling. Element 6 addresses lssues relating to the development of valid transport algorithms. Finally, there must be some means of verifying as far as is possible, the theoretical, experimental and model concepts evolving frot the recommendations of elements 2 through 6 . These are incorporated as recommendations for field evaluations in element 7 . This element also contains recommendations for studies designed to clarify and bound problems defined in elements 2 through 5 .

The organization of these elements differs from that of the issues presented Chapter 1-3 in Apps et al., (1982). This is because it was found that the recommendations emerging from the evaluations in this report had broader implications than the classification based on barriers alone. It is also consistent with the logic developed in Section 1.2.2, which allows for a sequential flow of information from the development of concepts through field verification. Furthermore, it avolds repetition of simllar topics for different barriers.

The recommendations classified according to elements 1 throug 7 lead naturally to both the specification and delineation of research needs. The final column of Table 2.1 represents the disposition of each recomendation. Where projects are proposed, they are coded according to the classification scheme listed above. Proposed research is summarized in Table 2.2 starting on page 28. Not all of the recommendations would lead to research activities however. Some involve no action or alternatively limit the scope of proposed research. 


\section{2 .3 Level of Effort}

The levels of effort for the completion of research for each project, and given in Table 2.2 , are in reality intultive estinates based on the judgenent of experts in the save or related fields. Better estimates can not be ande at this stage of prograv developwent. The level of effort could vary, depending on the scientific taff ultinately resfsonible for a project. Accurate estinates would also necessitate detafled task breakdowns for each project, a laborlous exercise that would require the participation of potential principal investigators, and which is beyond the scope of this report. The inital guesses may be optimistic, as is invariably the case, and more careful scoping may project greater efforts than are given here.

Final planning prior to iwplementation may also necessitate that a particular research project be accelerated to resolve a particular issue earlier in the course of the program. An accelerated project would require additional scientific staff who might not perform the needed research in as efficient a manner as a smaller group would over a longer period.

\section{2 .4 Time Requirements}

Estimates of time requirements to complete a project suffer from the same limitations as those for levels of effort (above). Time requirements are also constrained by the need to accomplish sufficient research to accommodate DOE schedules for construction a repository. The duration of various projects should therefore be adjusted to meet this schedule, and the levels of effort altered accordingly. A rigorous attempt to meet this constraint has not been attempted in the present planning effort.

Time requirements are also given with each project in Table 2.2 .

\section{2 .5 Cost}

The present cost of supporting one staff scientist at a major research institution $1 \mathrm{~s}$ approximately $\$ 100 \mathrm{~K}$ pra. This figure includes basic salary, fringe benefits, overhead and supporting services, but does not cover the cost of techniclans, capital equipment or other unusual expenses. This approximate figure may be used to estimate both annual and cumulative costs for the geochenistry research program.

\subsection{COMPARISON WITH ONGOING RESEARCH}

Summaries of research programs underway in 1981 , and relating to the chemistry of waste isolation in geologic repositories both in the United states and elsewhere, are summarized in Appendix B. These projects are correlated with the proposed research emerging from the recommendations from Apps et al., (1982) as widicated at the foot of each project page in Table 2.2. Many of the ongoing research projects are specific to particular rock types and these have also been identified for each project. 
Table 2.2. Proposed Projects.

\section{ELEREN 1. GOUNDING CONDITIONS}

\section{Profect: 1.1 (CHAMGES IN MACKFILL PROPERTIES)}

Iitle: Investigate, in the laboratory, long-term changes in physical and chenical properties of beckfilis subjected to repository conditions. ip 500 bars max, $T=300^{\circ} \mathrm{C}$ max.)

Priority: B Changed physical and chemical properties of the backfill will Influence the rate of radionuclide nigration in as yet undeterulned ways. This will affect predictions of radionuclide containment at a given repository.

Justification: The physical and chemlcal properties of backfills and host rocks can change markedly in the time between waste emplacement and possible release of radionuclides $(1,000$ years). The initial properties of the barrier media may therefore bear little relationship to those encountered by migrating radionuclides.

Expected Results: Properties of backfills and host rocks will be determined. Those whose properties cannot be predicted will be rejected as suitable barrler media.

Effort : FTE p.a. - 8; Duration - 3 years

Notes: This project applies primarily to backfill. Comparison with natural analogues, e.g., Project 5.1, would help. Task would be simplifled if lower repository temperatures were permitted by policy.

\begin{tabular}{|c|c|c|c|c|c|c|c|c|}
\hline \multicolumn{2}{|c|}{ Link* } & & & \multicolumn{5}{|c|}{ Existing Projects } \\
\hline In & Out & Salt (D) & Salt (B) & Basalt & Tuff & Granite & Shale & Other \\
\hline & 7.11 & & $19 ?$ & $\begin{array}{l}21,22 \\
45 ?\end{array}$ & & & $35 ?$ & $\begin{array}{l}18 ?, 20 \\
44,89, \\
90\end{array}$ \\
\hline
\end{tabular}

tSee Section $2.2 .3, p .27$

* See Section 2.4 .1$, p. 91 
Table 2.2 (coat.)

ELEMENT 1 (cont.)

Project: 1.2 (UNCONTAMINATED SArPLING)

T1tle: Develop groundwater sampling procedures for uncontaninated anple procurenent.

Priority: If the research is not successfully accomplished, estimation of radionuclide migration rates through the barrier systen will be impaired, and predictions of the degree of containment of a given repository will be less certaln. This could necessitate rejection of an otherwise acceptable site.

Justification: Uncontaminated groundwater samples are essential for establishing baseline conditions and interpretation of regional and local hydrology. Existing techniques are not adequate, particularly in lowpermeability formations.

Expected Results: Downhole and underground samplers will be capable of securing a sample of water sufficient for comprehensive chemical and Isotopic analyses.

Effortt: FTE p.a. - 4; Duration - 2 years

sotes: Engineering design and fabrication are Included.

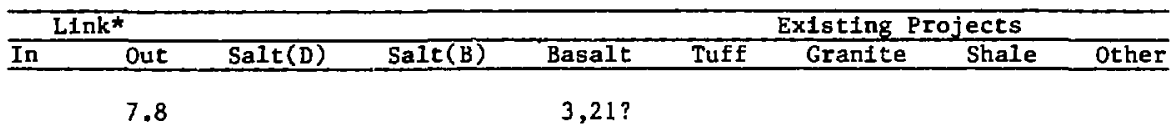

tSee Section 2.2.3, p. 27

*See Section 2.4.1, p. 91 
Table 2.2 (cont.)

ELERERT 1 (cont.)

PTOject: 1.3 (GROUNDWATER OXIDATION STATE)

Titlc: Develcp and denonstrate a definitive means of characterizing the oxidation state of groundwaters.

Priority: B See Project 1.2.

Justification: The transport of several toxic radionuclides is depender. upon oxidation state $\left(\mathrm{e} . \mathrm{g} \cdot,{ }^{99} \mathrm{Tc}, 240_{\mathrm{Pu},}{ }^{239} \mathrm{Pu}\right)$. Also, canister integrity and engineered barrier properties are affected by oxidation state. Unambiguous and reliable methods of measuring the oxidation state in groundvaters have not been demonstrated.

Effort 1 : FTE p.a. - 1.5; Duration - 2 years

Expected Results: A satisfactory fieldable technique will be developed.

\begin{tabular}{|c|c|c|c|c|c|c|c|c|}
\hline \multicolumn{2}{|c|}{ Link* } & & & & \multicolumn{3}{|c|}{ Existing Projects } & \\
\hline$\overline{\text { In }}$ & Out & Salt(D) & Salt(B) & Basalt & Tuff & Granite & Shale & Other \\
\hline & 7.8 & & & $103 ?$ & & & & 2,98 \\
\hline
\end{tabular}

tSee Section 2.2 .3 , p. 27

*See Section 2.4 .1 , p. 91 
Tabie 2.2 (cont.)

ELEMENT 2. TRANSPORTED FORMS

Inorganic Complexes

Project: 2.1 (COMPLEXES OF FISSION PRODUCTS)

T1tle: Investigate the 1norganic complexes of fission product elements such as Se, Sn, Pd, and $\mathrm{Tc}$ at temperatures to $175^{\circ} \mathrm{C}$ in natural groundwaters.

Priority: A Migration rates of the listed fission products under reposicory conditions are not known. Therefore there is presently no means of defining barrier parameters necessary for their containment. Without this knowledge, criteria will not exist to determine the acceptability of a given site.

Justification: The aqueous speciation of selenium and the relative importance of Sn and Pd complexes in solution are not known. It is also not clear what the most stable oxidation state of Tc is in solution. Complexation of these elements with respect to common anions such as $\mathrm{OH}_{3}^{-} \mathrm{Cl}^{-}, \mathrm{HCO}_{3}{ }^{-}, \mathrm{CO}_{3}{ }^{2-}, \mathrm{SO}_{4}{ }^{2-}$, and $F$ should also be investigated.

Expected Results: The chem1stry of Se, Sn, Pd, and Tc in groundwater will be determined. Initial results will be obtained at $25^{\circ} \mathrm{C}$, possibly narrowing scope of research at temperatures to $175^{\circ} \mathrm{C}$.

Effort : FTE p.a. - 3; Duration - 2 years

Notes: The significance of these species may be modified as a result of estimates of maximum fluxes of these elements based on the solubilities of precipitated solids as determined under Project 4.9. Groundwater compositions at elevated temperatures must also be known.

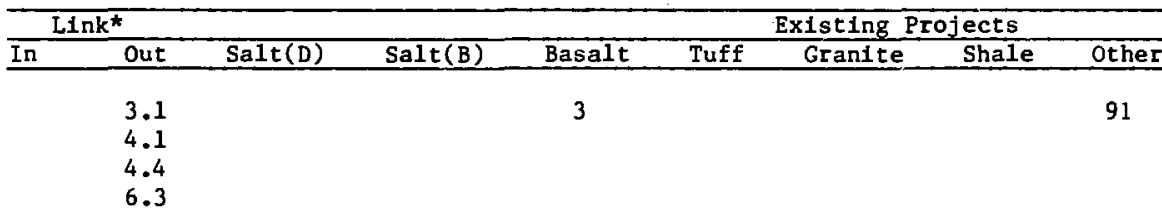

tSee Sectian 2.2.3, p. 27

* See Section 2.4.1, p. 91 
Table 2.2 (cont.)

ELEMENT 2 (cont.)

Inorganic Complexes (cont.)

Profect: 2.2 (MASS TRANSPORT IN A THERHAL GRADIENT)

Title: Conduct mass transport exferiments in the laboratory under simulated thermal conditions using site specific material from the near-field region.

Priority: B Changes in physical properties of near-field host rocks will affect the rate of radionuclide migration in as yet undetermined ways. This will affect predictions of radionuclide containment at a given repository.

Justification: It is not known how mass transport in thermal gradients may affect perweability and porosity in the near ffeld. The purpose of this project is to elucidate chemical processes that might occur and establish their significance.

Expected Results: Qualitative estimates of chenlcal transport 1n the near fleld will be accomplished.

Effort: FTE p.a. - 2; Duration - 2 years

Notes: Th1s project is similar to Project 5.2, but relates specifically to near-fieid alteration from specific sites.

\begin{tabular}{|c|c|c|c|c|c|c|c|c|}
\hline \multicolumn{2}{|c|}{ LInk* } & \multirow[b]{2}{*}{ Salt(D) } & \multirow[b]{2}{*}{ Salt(B) } & \multirow[b]{2}{*}{ Basalt } & \multicolumn{4}{|c|}{ Existing Projects } \\
\hline $\overrightarrow{\text { In }}$ & Out & & & & Tuff & Granite & Shale & Other \\
\hline 2.4 & $\begin{array}{l}6.5 \\
7.9 \\
7.10 \\
7.11\end{array}$ & $\begin{array}{l}15 ?, 35, \\
38\end{array}$ & $\begin{array}{l}15 ?, 35, \\
38\end{array}$ & 21 & & 4,12 & $13 ?, 14$ & $20 ?, 71$ \\
\hline
\end{tabular}

tSee Section 2.2 .3 , p. 27

*See Section 2.4.1, p. 91 
Table 2.2 (cont.)

ELEMENT 2 (cont.)

Inorganic Complexes (cont.)

Project: 2.3 (COHPLEXES OF ACTINIDES)

Title: Investigate inorganic complexation of actinides and their daughters at temperatures to $175^{\circ} \mathrm{C}$ in. natural groundwaters.

Priority: A Without information on the inorganic complexation of actinides and their daughters in the cemperature range of interest, it will be impossible to predict the barrier thickness or compositions required to contain them. This could affect the design of a repository and selection of a site.

Justification: Little is known about aqueous inorganic speciation of actinides and some of their daughters under conditions expected in typical groundwaters. Specifically, the complexation constants of relevant actinides (especially Am and $\mathrm{Cm}$ ) with phosphate and the complexation constants of trivalent and tetravalent actinfdes with carbonate and hydroxyl species should be measured. In addition, the role of $\mathrm{UO}_{2}{ }^{+}$and $\mathrm{PuO}_{2}{ }^{+}$in controlling solution concentrations should be established.

Expected Results: The role of actinide complexes in radionuclide transport will be clarified.

Effortt: FTE p.a. - 3.5; Duration -3 years

Notes: Significance of these complexes may be modified as a result of estimates of maximum fluxes of elements based on solubilities of precipitated solids as determined under project 4.10. Groundwater compositions at elevated temperatures must also be known.

\begin{tabular}{|c|c|c|c|c|c|c|c|c|}
\hline \multicolumn{2}{|c|}{ Link* } & & & & \multicolumn{3}{|c|}{ Existing Projects } & \\
\hline$\underline{I n}$ & Out & $\operatorname{salt}(D)$ & Salt(B) & Basalt & Tuff & Granfte & Shale & Other \\
\hline 2.4 & $\begin{array}{l}3.1 \\
4.2 \\
4.4 \\
6.3\end{array}$ & & $19 ?$ & & & & & $\begin{array}{l}2,16, \\
17,90 ? \\
99\end{array}$ \\
\hline
\end{tabular}

tSee Section 2.2.3, p. 27

* See Section $2.4 .1, \mathrm{p} .91$ 
Table 2.2 (cont.)

ELEKENT 2 (cont.)

Inorgan1c Coaplexes (cont.)

Project: 2.4 (FLUID COMPOSITION TO $300^{\circ} \mathrm{C}$ )

T1tle: Investigate experimentally, in the laboratory, the effect of chemical reactions on fluid composition in the backfill and near field at temperatures between 25 and $300^{\circ} \mathrm{C}$.

Priority: C Groundwater composition at elevated tewperatures influences radionuclide migration by affecting the degree of complexing. The groundwater composition is 1 tself determined by the barrier medium. Therefore this project has implications for barrier selection and waste containment. Hoxever, existing thermochemical and experimental data may already give first-order estimates of significance.

Justification: Groundwater composition is modiflad by reaction with the barrier medium at elevated temperatures. This effect must be understood in predicting long-term processes of alteration (Projects 1.1 and 2.2) and radionuclide transport (Projects 2.1 and 2.3).

Expected Results: The variation in groundwater composition as a function of temperature will be determined.

Effort : FTE p.a. - 2.7; Duration - 3 years

Notes: Lack of thermodynamic data on solid phases as a function of temperature and thermodynamic properties of aqueous species could hinder accomplishment of this project.

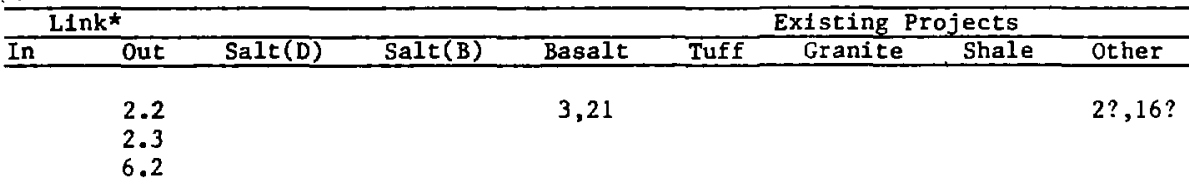

tSee Section 2.2.3, p. 27

*See Section 2.4.1, p. 91 
Table 2.2 (cont.)

ELEMENT 2 (cont.)

Organic Conplexes

Project: 2.5 (ORGANIC COMPLEXES)

Title: Investigate organic complexes of important fission product elements and actinides.

Priority: B If organic complexes of actinides are significant, they could influence radionuclide containment in a repository, thereby affecting repository design and site selection.

Justification: If organic complexes are present in groundwater, their identification and significance in transporting radionuclides should be established.

Expected Results: Certain organic complexes will be found significant in a limited number of environments.

Effortt: FTE p.a. - 4; Duration - 2 years

Notes: Estimates of effort required are very speculative. This research depends on a prior demonstration of significance from field measurements under Project 7.1 .

\begin{tabular}{|c|c|c|c|c|c|c|c|c|}
\hline \multicolumn{2}{|c|}{ Link* } & & & & \multicolumn{4}{|c|}{ Existing Projects } \\
\hline In & Out & Sale(D) & Salt (B) & Basalt & Tuff & Granite & Shale & Other \\
\hline 7.1 & $\begin{array}{l}4.3 \\
6.3\end{array}$ & & & 3,59 ? & & & & $\begin{array}{l}1,2 ? \\
16 ?, 90\end{array}$ \\
\hline
\end{tabular}

tSee Section 2.2 .3 , p. 27

*See Section 2.4.1, p. 91 
Table 2.2 (cont.)

ELEMENT 2. (cont.)

Organic Coaplexes (cont.)

Project: 2.6 (HUMIC-FULVIC ACID COMPLEXES)

Priority: B See Project 2.5.

Title: Determine the stability constants, electrochemical data, and chemical characteristics of radionuclide/humic-fulvic and related carboxylic acid complexes.

Justiffcation: Naturally occurring humic-fulvic acids and related carbolic acid complexes may be major complexing agents of several important radionuclides.

Effort : FTE p.a. - 3; Duration - 2 years

Expected Results: Stability constants of complexes of humic-fulvic actds with significant radionuclides will be determined.

\begin{tabular}{|c|c|c|c|c|c|c|c|c|}
\hline \multicolumn{2}{|c|}{ L1nk* } & & & & \multicolumn{4}{|c|}{ Existing Projects } \\
\hline In & Out & Salt(D) & Salt(B) & Basalt & Tuff & Granite & Shale & Other \\
\hline 7.1 & $\begin{array}{l}4.3 \\
6.3\end{array}$ & & & 3 & & & & 37,49 \\
\hline
\end{tabular}

tSee Section 2.2 .3$, p. 27

*See Section 2.4 .1$, p. 91 
Table 2.2 (cont.)

ELEMENT 2 (cont.)

\section{Collo1de}

\section{Project: $2 . \bar{T}$ (COLLOIDS EROM HIL)}

Title: Examine the properties and radionuclide content of colloidal forms produced through the degradation of high-level wastes by groundwaters.

Priority: C If colloids form in significant amounts, radionuclide containment could be decreased, thereby affecting repository design and site selection.

Justification: Colloldal particles as a source of radionuclides is neither established nor quantified. This should be done.

Expected Results: Concentration of colloidal particles and the resulting radionuclide flux will be determined. If significant, it should be incorporated in transport nodels.

Effort : FTE p.a. - 2; Duration - 2 years.

Notes: The significance of the transport mechanism has yet to be demonstrated. If radiocolloid transport is negligible, then production of radiocolloids at the source will not be significant.

\begin{tabular}{|c|c|c|c|c|c|c|c|c|}
\hline \multicolumn{2}{|c|}{ Link* } & \multirow[b]{2}{*}{ SaIt (D) } & \multirow[b]{2}{*}{ Salt(B) } & \multicolumn{5}{|c|}{ Existing Projects } \\
\hline In & Out & & & Basalt & Tuff & Granite & Shale & other \\
\hline 3.5 & 6.13 & & & $3,21 ?$ & & & & $85 ?$ \\
\hline
\end{tabular}

tSee Section $2.2 .3, \mathrm{p} .27$

*See Section 2.4 .1 , p. 91 
Table 2.2 (cont.)

ELEAENT 2 (cont.)

Colloide (cont.)

\section{Prołect: 2.8 (RADIONUCLIDE COLLOIDS)}

Title: Produce true collolds of Insoluble species of toportan: radionuclides under groundwater conditions anticipated at the waste-storage site.

Priority: B See Project 2.7.

Justification: Changes in oxidation state or concentrations of other components in the groundwater can cause gross supersaturation and consequent colloid formation. The potentlal significance of this phenomenon should be established.

Expected Results: The conditions under which colloid formation could occur and with which elements will be determined. The significance of radionuclide colloids in radionuclide migration will be established.

Effortt: FTE p.a. - 2; Duration - 2 years

Notes: This research will depend on data being avallable from Projects 2.1 and 3.3.

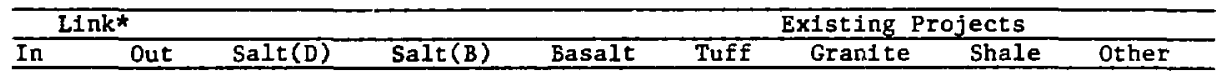

$3.56 .13 \quad 19$ ?

1,17 , 85 ?

tSee Section 2.2.3, p. 27

*See Section 2.4.1, p. 91 
Table 2.2 (cont.)

ELEMENT 3. TRANSPORT MECHANISMS

Project: 3.1 (DIFFUSIVITIES RESEARCH)

Title: Measure diffusion coefficlents of solute species to $175^{\circ} \mathrm{C}$.

Priority: B Higher diffusion rates of radionuclide species at elevated temperatures will decrease radionuclide containment. This effect must be taken into account because of its impact on repository design and site selection.

Justification: Diffusion coefficients are known only for a limited number of solute species at $25^{\circ} \mathrm{C}$. Data on relevant species to $175^{\circ} \mathrm{C}$ must be obtained to permit adequate modeling of radionuclide transport.

Expected Results: Data on diffusion coefficients of relevant species will be obtained.

Effortt: FTE p.a. - 4; Duration - 2 years

Notes: Diffusion coefficients of most aqueous species are similar. Scope could be reduced with a few actual measurements. Relevent species must be identified through Projects 2.1 and 2.3 .

\begin{tabular}{|c|c|c|c|c|c|c|c|}
\hline \multicolumn{2}{|c|}{ L1nk* } & & & \multicolumn{4}{|c|}{ Existing Projects } \\
\hline In & Out & Salt(D) & $\operatorname{Salt}(B)$ & Basalt & Tuff & Granite & Other \\
\hline $\begin{array}{l}2.1 \\
2.3\end{array}$ & $\begin{array}{l}6.6 \\
3.3\end{array}$ & & & & & & $54 ?$, \\
\hline
\end{tabular}

tSee Section 2.2 .3 , p. 27

*See Section 2.4.1, p. 91 
Table 2.2 (cont.)

ELEMENT 3 (cont.)

\section{Project: 3.2 (DIFFUSIVITIES)}

Title: Establish significance of variation in diffusion coefficients among different aqueous radionuclide complexes and thelr variation with temperatire.

Priority: C Varlations in diffusion rates of species in solution will Influence the relative retardation of different radionuclides in the backfill. This will affect repository design and site selection, which, however, is expected to be minor.

Justification: Variation in the magnitude of diffusion coefficients of different aqueous species may be small in comparison with the magnitude of errors from other sources when predicting radionuclide migration. This needs to be established before further research is done on this subject.

Effort ${ }^{\prime}$ FTE p.a. - 1; Duration - 1 year

Expected Results: The significance of diffusion coefficient variations will be established and predictions of radionuclide migration will be made.

\begin{tabular}{|c|c|c|c|c|c|c|c|c|}
\hline \multicolumn{2}{|c|}{ Link* } & \multirow[b]{2}{*}{ Salt(D) } & \multirow[b]{2}{*}{ Salt(B) } & & \multicolumn{3}{|c|}{ Existing Projects } & \\
\hline$\overline{\text { In }}$ & out & & & Basalt & Tuff & Granite & Shale & Other \\
\hline
\end{tabular}

3.1

tSee Section 2.2 .3 , p. 27

*See Section 2.4.1, p. 91 
Table 2.2 (cont.)

ELEMENT 3 (cont.)

Project: 3.3 (CROSS DIfFustonal COUPLING)

Title: Investigate significance of cross diffusional coupling and coupling of mass fluxes to thermal fluxes.

\section{Priority: C See Project 3.2.}

Justification: The significance of cross coupling of diffusional fluxes and coupling of mass to thermal fluxes is neither established nor quantifled. These phenomena should be evaluated to $175^{\circ} \mathrm{C}$.

Expected Results: The significance of the phenomena will be determined.

Effortt: FTE p.a. - 1; Duration - 2 years

Notes: Should the phenomena studled prove significant, further research will be needed. Species to be studied will be identified under Projects 2.1 and 2.3 .

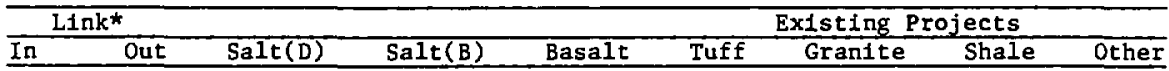

$3.1 \quad 3.4$

tSee Section $2.2 .3, p .27$

*See Section 2.4.1, p. 91 
Table 2.2 (cont.)

ELEMENT 3 (cont.)

Project: 3.4 (CROSS DIFFUSIONA COUPLING RESEARCF)

Titie: Determine magnitude of cross diffusional coupling and coupling of ans fluxes to thermal fluxes.

Priority: C See Project 3.2.

Justification: If cross coupling of diffusional fluxes and coupling of mass to thermal fluxes is proved significant, these phenomasa should be quantifled to $175^{\circ} \mathrm{C}$.

Effort: FTE p.a. - 4; Duration - 2 years

Expected Results: Data on the magnitude of the cross diffusional coupling phenomena will be obtained.

\begin{tabular}{|c|c|c|c|c|c|c|c|c|}
\hline \multicolumn{2}{|c|}{ Link* } & \multirow[b]{2}{*}{ SaIt(D) } & \multirow[b]{2}{*}{$\operatorname{Sale(B)}$} & \multirow[b]{2}{*}{ Basalt } & \multicolumn{3}{|c|}{ Existing Projects } & \\
\hline In & out & & & & Tuff & Granite & Shale & Other \\
\hline
\end{tabular}

$3.3 \quad 6.7$

tsee Section 2.2 .3$, p. 27

* See Section 2.4 .1 , p. 91 
Table 2.2 (cont.)

ELEHENT 3 (cont.)

\section{Project: 3.5 (COLLOID DIFFUSION)}

Title: Deternine experinentally whether solloidal particles wil diffuse through rock and backf111 pores. Esteblish the relative inportance of radionuclide transport by colloid diffusior.

Priority: C If radicauclide-containing colloids diffuse at a sigatficant rate, they could affect radi inuclide containuent in the backfill. This will impact repository design and site selection, which, however, is expected to be inor.

Justification: Calculations show that gravity settling will remove all uncharged particles greater than $0.01 \mu \mathrm{m}$ from solution, thereby suggesting that colloidal transport may not be significant unless the particles are charged. Theoretical predictions on uncharged colloids must be verified experimentally. The effect of charge on colloid transport must be established. Sensitivity studies should establish whether transport of radionuclide-containing colloids is significant.

Expected Results: Theoretical results will be verified.

Effort 1 FTE p.a. - 2; Years - 2

Notes: Results of this study will affect relevance of Projects 2.5 and 2.6.

\begin{tabular}{|c|c|c|c|c|c|c|c|c|}
\hline \multicolumn{2}{|c|}{ Link* } & & & & \multicolumn{3}{|c|}{ Existing Projects } & \multirow[b]{2}{*}{ Other } \\
\hline In & Out & Salt(D) & Salt (B) & Basalt & Tuff & Grantre & Shale & \\
\hline & $\begin{array}{l}2.7 \\
2.8 \\
6.8\end{array}$ & & & & & & & $85 ?$ \\
\hline
\end{tabular}

tSee Section 2.2 .3$, p. 27

*See Section 2.4 .1$, p. 91 
Table 2.2 (cont.)

ÉLEENT 3 (cont.)

\section{Project: 3.6 (INTERPRET BACKFILI CHANGES)}

Iitle: Reconcile experinental scudies of long-term changes in phy. zal and chemical properties of backf 111 materials with chenistry of $c$ existing groundwater.

Priority: A The selection of backfills possessing the needed integrity and stability is essential to the design of a waste repository. Without this knowledge, radionuclide cor zalnment and canister integrity is thrown In doubt.

Justification: The mechanisms bringing about changes in backfill properties must be understood if long-term projections are to be made regarding the stability of backflll materials.

Effort : FTE p.a. - 1; Duration - 1 year

Expected Results: Mechanisms will be Identified and quantified.

\begin{tabular}{|c|c|c|c|c|c|c|c|c|}
\hline \multicolumn{2}{|c|}{ Link } & & & & \multicolumn{3}{|c|}{ Existing Projects } & \\
\hline In & Out & Salt(D) & Salt (B) & Basalt & Tuff & Granite & Shale & Other \\
\hline $\begin{array}{l}1.1 \\
2.4 \\
6.1\end{array}$ & $\begin{array}{l}6.5 \\
7.11\end{array}$ & & & 21,22 & & & & 20 \\
\hline
\end{tabular}

tSee Section 2.2 .3$, p. 27

*See Section 2.4 .1 , p. 91 
Table 2.2 (cont.)

ELEMENT 4. RETARDATION MECHANISHS

Adsorption

\section{Project: 4.1 (ADSORPTION FUNDAMENTALS)}

Title: Exanine the fundamental relationship between selected radionuclide sorption sechanises and the surface area of mineral aggregates.

Priority: D Information on sorpetion fundamentals will facilitate the development of models describing radionuclide transport, possibly accellerating the resolution of geochemistry issues.

Justification: The relationship between mineral surface area and radionuclide adsorption 18 not clearly defined. Without understanding both the mechanisms of adsorption or thelr relationship to surfaces of minerals and mineral aggregates (rocks) $\mathrm{K}_{\mathrm{d}}$ 's cannot be defined in terms of measurable rock properties. There is therefore no way of relating laboratory sorption studies to field conditions.

Expected Results: A basis for models relating sorption phenomena ( $K_{d}{ }^{\prime} s$ ) to speciflc surfaces of rocks will be obtalned.

Effort : FTE p.a. - 4; Duration - 3 years

Notes: Th1s study requires fundamental knowledge of sorption of selected fission and actinide clements, much of which is in the process of being obtalned.

\begin{tabular}{|c|c|c|c|c|c|c|c|c|}
\hline \multicolumn{2}{|c|}{ Link* } & & & & \multicolumn{4}{|c|}{ Exiscing Projects } \\
\hline In & Out & Salt(D) & SaIt(B) & Basalt & Tuff & Granite & Shale & other \\
\hline $\begin{array}{l}2.1 \\
4.5 \\
4.6\end{array}$ & $\begin{array}{l}5.6 \\
6.4\end{array}$ & & $37 ?$ & 3 & & & & $\begin{array}{l}1,54, \\
84 ?\end{array}$ \\
\hline
\end{tabular}

tSee Section 2.2 .3 , p. 27

«See Section 2.4.1, p. 91 
Table 2.2 (cont.)

ELEREN 4 (cont.)

Adsorption (cont.)

\section{Project: 4.2 (SORPTION ON SPECIFIC MINERALS)}

Title: Examine sorption of selected radioelements on specific minerals.

Priority: B The selective sorption of some radionuclides by specific minerals may have a major effect on radionuclide retardation. This could affect backfill selection, repository design, and site selection.

Justification: Some radionuclides may sorb prefe-:entially on relatively minor minerals in host rocks, e.g., trivalent actinides on phosphates or technetium on sulfides. Consequently, these minerals could strongly affect migration of specific radionuclides. This possibility should be clarified.

Expected Results: Minor phases having significan z retardation impact with respect to specific radionuclides will be identified.

Efforti. FTE p.a. - 2; Duration - 3 years

Notes: The magnitude of this study is difficult to estimate because the scope of research needed is not known.

\begin{tabular}{|c|c|c|c|c|c|c|c|c|}
\hline \multicolumn{2}{|c|}{ LInk* } & \multirow[b]{2}{*}{ Salt(D) } & \multirow[b]{2}{*}{ Salt(B) } & \multirow[b]{2}{*}{ Basalt } & \multicolumn{3}{|c|}{ Existing Projects } & \multirow[b]{2}{*}{ Other } \\
\hline In & Out & & & & Tuff & Grantte & Shale & \\
\hline $\begin{array}{l}2.3 \\
4.5 \\
4.6\end{array}$ & $\begin{array}{l}6.4 \\
6.4\end{array}$ & & 19? & 3,103 & & & & $1 ?, 54$ \\
\hline
\end{tabular}

tSee Section 2.2.3, p. 27

* See Section 2.4 .1 , p. 91 
Table 2.2 (cont.)

ELEMENT 4 (cont.)

Adsorption (cont.)

\section{Project: 4.3 (ORGANIC SORPTION)}

Title: Study sorption of radionuclide organtc complexes on mineral surfaces.

\section{Priority: B See Project 2.5.}

Justification: If organic complexes are significant in causing radionuclide transport, then their sorption properties must be understood.

Expected Results: The sorption of organic complexes as a function of aqueous phase and substrate composition wlll be obtained.

Effort : FTE p.a. - 3; Duration - 2 years

Notes: This research should be inftiated only after the fmportance of metal organic complexes has been established and organic spectes

identified (Projects 2.4 and 7.1 ).

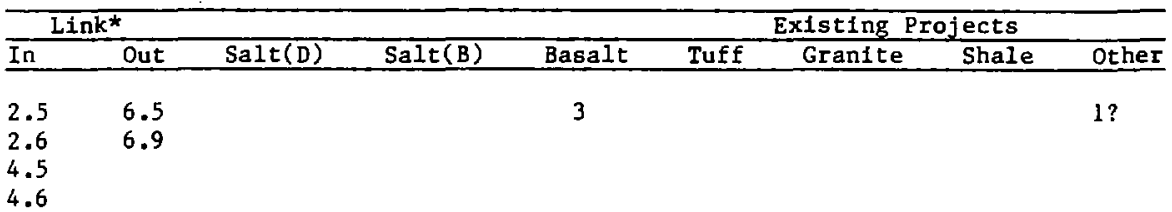

tSee Section 2.2 .3$, p. 27

*See Section 2.4.1, p. 91 
Table 2.2 (cont.)

ELENENT \& (cont.)

Adsorption (cont.)

Project: 4.4 (SORPTION TO $175^{\circ} \mathrm{C}$ )

Title: Conduct a few carefully controlled adsorption experiments at tenperatures to $175^{\circ} \mathrm{C}$ to establish empirical or preferably theoretical tenperature dependence of sorption.

Priority: A Because sorption of radionuclides could be dramatically affected by tenperature, radionuclide retardation would be likewise affected in a repository. This would impact repository design and site selection.

Justification: Virtually nothing is known about the temperature dependence of adsorption. Thls should be understood, as it could have a significant effect on retardation in the thermal regime of the repository.

Expected Results: Adsorption as a function of various solution parameters and temperature for one simple case (e.g., Cs) and one or two other important radionuclides (e.g*, Tc and $\mathrm{Pu}$ ) will be determined.

Effortt: FTE p.a. - 3; Duration - 3 years

Notes: Experiments are expected to be difficult to perform.

\begin{tabular}{|c|c|c|c|c|c|c|c|c|}
\hline \multicolumn{2}{|c|}{ Link* } & & & & \multicolumn{3}{|c|}{ Existing Projects } & \\
\hline In & Out & Salt(D) & Salt (B) & Basalt & Tuff & Grantte & Shale & Other \\
\hline $\begin{array}{l}2.1 \\
2.3 \\
4.5 \\
4.6\end{array}$ & 6.4 & & $55 ?$ & $3,21 ?$ & & & $55 ?$ & 1,84 \\
\hline
\end{tabular}

tSee Section $2.2 .3, p, 27$

*See Section 2.4.1, p. 91 
Tabie 2.2 (cont.)

ELEAENT 4 (cont.)

Adsorption (cont.)

\section{Project: 4.5 (MINERAL SURFACE CHANGES I)}

T1tle: Conduct laboratory and theoret1cal studies to deterwine longterm changes in mineral surfaces and their effect on radionucifde adsorption.

Prforfty: A Long-term sorption reactions could have a dramatic effect In retarding radionuclides in the far field. This would have ramifications in repository design and site selection.

Justiflcation: Research is needed to establish the validity or otherwise of short-term sorption studies and to assess the Impact of "weathered" surfaces on sorption.

Expected Results: Preliminary findings wfll be obtalned to establish whether shnrt-term tests of radionuclide adsorption are meaningful.

Effort : FTE p.a. - 2; Duration - 2 years

Notes: Experiments may be difficult to design. Results may affect Projects 4.1 to 4.4 .

\begin{tabular}{|c|c|c|c|c|c|c|c|c|}
\hline \multicolumn{2}{|c|}{ Link* } & & & & \multicolumn{4}{|c|}{ Existing Projects } \\
\hline In & Out & Salt(D) & Salt(B) & Basalt & Tuff & Granite & Shale & Other \\
\hline 4.4 & $\begin{array}{l}4.1 \\
4.2 \\
4.3 \\
4.4 \\
4.6 \\
6.10\end{array}$ & & & 3 ? & & & $14 ?$ & $1 ?, 54$ \\
\hline
\end{tabular}

tSee Section $2.2 .3, p .27$

*See Section 2.4.1, p. 91 
Table $2.2($ cont. $)$

ELEMENT 4 (cont.)

Adeorption (cont.)

Project: 4.6 (MINERAL surface Changes II)

T1tle: Conduct laboratory and theoretical studies to deternine longterm changes in mineral surfaces and their effect on radionuclide adsorption.

Priority: A See Project 4.5 .

Justification: Research 1s needed to establish the validity or otherwise of short-term sorption studies and to assess the 1mpact of "weathered" surfaces on sorption.

Expected Results: A final determination will be made as to whether shortterm tests of radionuclide adsorption are meaningful. Long-term effects will be quantified.

Effort : FTE p.a. - 2; Duration - 2 years

Notes: Experiments may be difficult to design. Results may affect Projects 4.1 to 4.4 .

\begin{tabular}{|c|c|c|c|c|c|c|c|c|}
\hline \multicolumn{2}{|c|}{$\overline{\operatorname{LInk}}{ }^{\star}$} & & & & \multicolumn{4}{|c|}{ Existing Projects } \\
\hline In & Out & Salt(D) & Salt (B) & Basalt & Tuff & Granite & Shale & Other \\
\hline 4.5 & $\begin{array}{l}4.1 \\
4.2 \\
4.3 \\
4.4 \\
6.10\end{array}$ & & & 3 & & & $14^{\prime}$ & $1 ?, 54$ \\
\hline
\end{tabular}

tSee Section 2.2.3, p. 27

*See Section 2.4.1, p. 91 


\section{Table 2.2 (cont.)}

ELEMENT 4 (cont.)

Ion Exchange

\section{Project: 4.7 (SCOPE GRMIN BOUNDARY AND VOLUME DIFFUSION)}

Tizle: Perforo scoping studies of grain boundary and volume diffusion wechanisms in apfropriate winerals at temperatures to $175^{\circ} \mathrm{C}$ using state-of-the-art techniques (e.g*, XPS and Auger electron spectroscopy).

Priority: A Given boundary and volume diffusion could strongly influence radionuclide retardation and thereby affect repository design and site selection.

Justification: The significance of these mechanisws in retarding radionuclides is not established.

Expected Results: It will be determined whether these mechanisms are Important and whether further research should be done.

Effort : FTE p.a. - 2; Durat1on - 1 year

Notes: Care should be taken in the selection of appropriate radioelements for study: Continuation of study is Project 4.7 .

\begin{tabular}{|c|c|c|c|c|c|c|c|c|}
\hline \multirow{2}{*}{\multicolumn{2}{|c|}{ Link* }} & \multirow[b]{2}{*}{ Salt(D) } & \multirow[b]{2}{*}{ Salt(B) } & \multirow[b]{2}{*}{ Basalt } & \multicolumn{3}{|c|}{ Existing Projects } & \\
\hline & Out & & & & Tuff & Granite & Shale & Other \\
\hline
\end{tabular}

t See Section 2.2 .3 , p. 27

* See Section 2.4.1, p. 91 
Table 2.2 (cont.)

ELEMENT 4 (cont.)

Ion Exchange (cont.)

Project: 4.8 (STUDY GRAIN BOUNDARY AND VOLUME DIFFUSION)

Title: Perform detailed studies of grain boundary and volume diffusion in appropriate minerals to $175^{\circ} \mathrm{C}$.

\section{Prlority: A See Project 4.7 .}

Justification: Output from Project 4.5 indicates that such mechanisms are significant and relevant to radionuclide migration.

Expected Results: A deteraination will be made as to whether short-term tests of radionuclide adsorption are meaningful. Long-term effects will be quantified.

Effort : FTE p.a. - 2; Duration - 3 years

Notes: See note in Project 4.6.

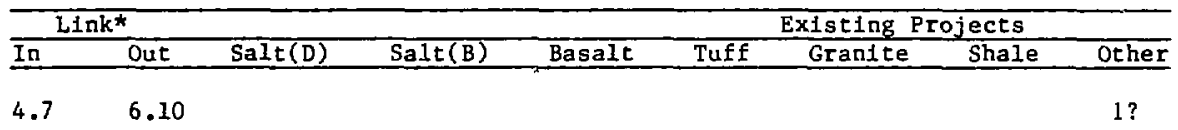

tSee Section 2.2 .3$, p. 27

*See Section 2.4 .1$, p. 91 
Table 2.2 (cont.)

ELEMENT 4 (cont.)

\section{Precipitation}

\section{Project: 4.9 (Sn AND Pd SOLUBILITY)}

Title: Determine the relative 1mportance of $\mathrm{Sn}$ and $\mathrm{Pd}$ solution species and their effect on $\mathrm{Sn}$ and $\mathrm{Pd}$ solubility in the natural environment.

Priority: B Sn and Pd solubility should be determined to establish whether special measures need to be taken in designing the barrier system of a repository.

Justiflcation: Research on solid phases of specific radioelements is needed to ascertain the maximum concentration of these elements in natural groundwaters and whether they are significant in controliling radionuclide transport.

Effort : FTE p.a. - 2; Duration - 3 years

Expected Results: Relevant phases will be Identified and their solubility products obtained.

\begin{tabular}{|c|c|c|c|c|c|c|c|c|}
\hline \multicolumn{2}{|c|}{ LInk* } & \multirow[b]{2}{*}{ Salt(D) } & \multirow[b]{2}{*}{ Salt(B) } & \multicolumn{5}{|c|}{ Existing Projects } \\
\hline In & Out & & & Basalt & Tuff & Granite & Shale & Other \\
\hline
\end{tabular}

6.3

tSee Section $2.2 .3, p .27$

*See Section 2.4.1, p. 91 
Table $2.2($ cont.)

ELEMENT $4(\operatorname{cont}$.

Precipitation (cont.)

\section{Project: 4.10 (ACTINIDE PRECIPITATES)}

Title: Identify and deternine solubility products of trivalent actinide phosphate compounds and trivalent and tetravalent carbonates and silicates of actinides.

Priority: B It is expected that actinide solid phase solubilities will be relatively low. However, they must be quantifled in order to establish whether special measures need to be taken later in designing the barrier system of a repository.

Justification: Same as Project 4.9

Effort : FTE p.a. - 3; Duration - 3 years

Expected Results: Same as Project 4.9

\begin{tabular}{|c|c|c|c|c|c|c|c|c|}
\hline \multicolumn{2}{|c|}{ LInk* } & & & & \multicolumn{3}{|c|}{ Exlsting Projects } & \\
\hline In & Out & Sale(D) & Salt(B) & Basalt & Tuff & Granite & Shale & Other \\
\hline
\end{tabular}

tSee Section 2.2.3, p. 27

*See Section 2.4 .1 , p. 91 
Table 2.2 (cont.)

ELEYENT 5. PHYSICAL/CHEMICAL PROPERTIES OF BARRIERS

Prec1p1tarion (cont.)

\section{Project: 5.1 (ALTERATION OF BASALTS AND GRANITES)}

T1tle: Review and quantify alteration of basalts and granites under the hydrothermal conditions expected 1.1 the near field in a repository. Predict anticipated secondary minerals for given bulk compositions.

Prlority: A Understanding how basalts and granites alter in the near field Is needed so that the suitability of these rocks as hosts for a repository can be evaluated. This will affect site selection.

Justification: Considerable uncertainty exists as to how basalts and granites will alter in the near field when subjected to the thermal pulse caused by radionuclide decay.

Effortt: FTE p.a. - I; Duration - J. years

Expected Results: Semiquantitative estimates will be wade of the secondary phase assemblages expected during alteration in the near field.

\begin{tabular}{|c|c|c|c|c|c|c|c|c|}
\hline \multicolumn{2}{|c|}{ Link* } & & & & \multicolumn{4}{|c|}{ Existing Projects } \\
\hline$\overline{\text { In }}$ & Out & Salt(D) & SaIt (B) & Basalt & Tuff & Granite & Shale & Other \\
\hline & 5.3 & & & $\begin{array}{l}21,22 \\
34\end{array}$ & & & $12 ?, 4$ & \\
\hline
\end{tabular}

tSee Section 2.2 .3 , p. 27

*See Section 2.4.1, p. 91 
Table 2.2 (cost.)

ELERENT 5 (cont.)

\section{Project: 5.2 (BACKFILL, COMPACTION)}

Title: Evaluate the effect of pressure on the conpaction of kackfill interials and the relation of this to porosity, permeability, tortuosity, specific surface area, diffusivities of lons, and radionuclide migration as a function of teaperature and chenical saturation state.

Priority: A This research is needed so that the performance of engineered backfill barriers may be predicted. This affects repository design.

Justification: Most studies of radionuclide sorption are made on disaggregated or uncompacted waterial, neither of which is representative of In situ conditions. The effect of compaction must be evaluated to assess its significance.

Expected Results: The variation in physical parameters as a function of pressure, temperature, and chemical saturation state will be obtained.

Effort ${ }^{\dagger}$ FTE p.a. - 4; Duration - 4 yeare

Notes: Experiments could be difficult to perform because of transient behavior. The project could be divided into subtasks.

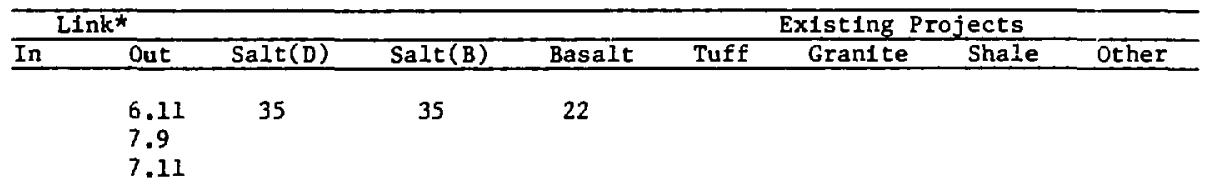

tSee Section $2.2 .3, p .27$

*See Section 2.4.1, P. 91 
Iable 2.2 (cont.)

ELETIENT 5 (cont.)

\section{Code: 5.3 (PRECIPITATION AND PERHEABILITY)}

Title: Conduct asss tranaport experiments to measure dissolution and precipitation and $1 \mathrm{tg}$ effect on permeability and porosity of backfill and host rock materials at temperatures to $300^{\circ} \mathrm{C}$.

Priority: A See Project 1.1.

Justification: Temperature gradients around canisters may 1nduce chemical migration that will effect permeability and porosity of the barrier nedium.

Expected Results: Varlations in permeability and porosity as a function of time and thermal gradient will be obtained. The information may be Incorporated into a single model.

Effortt: FTE p.a. - 2; Duration - 3 years

Notes: This project is similar to Project 2.2 but relates primarily to backf 111 alteration.

\begin{tabular}{|c|c|c|c|c|c|c|c|c|}
\hline \multicolumn{2}{|c|}{ Link ${ }^{\star}$} & \multirow[b]{2}{*}{ Salt (D) } & \multirow[b]{2}{*}{ Salt(B) } & \multicolumn{5}{|c|}{ Existing Projects } \\
\hline$\overline{\text { In }}$ & Out & & & Basalt & Tuff & Granite & Shale & Other \\
\hline
\end{tabular}

$5.1 \quad 15 ? \quad 15 ? \quad 21 ?, 22 ?$

tSee Section 2.2 .3 , p. 27

* See Section 2.4 .1 , p. 91 
Table 2.2 (cont.)

ELEHENT 5 (cont.)

Project: 5.4 (OXYGEN UPTAKE)

Title: Perforn laboratory studies to measure the uptake of oxygen in granites, rhyolitic tuff, or oxidized argillites.

Priority: B Project may affect backfill barrier design, especially if waste is stored in granitic or acidic tuffaceous rocks.

Justification: Low oxygen uptake in rocks poor in ferrous iron could lead to long-term persistence of oxidizing conditions unless appropriate remedial action is taken.

Effort*: FTE p.a. - 0.5 ; Duration 2 years

Expecte: Results: A quantitative measure of oxygen uptake will be made and remedies recommended.

\begin{tabular}{|c|c|c|c|c|c|c|c|c|}
\hline \multirow{2}{*}{\multicolumn{2}{|c|}{$\begin{array}{l}\text { Link* } \\
\text { On }\end{array}$}} & \multirow[b]{2}{*}{ Salt(D) } & \multirow[b]{2}{*}{ Salc(B) } & \multirow[b]{2}{*}{ Basalt } & \multicolumn{3}{|c|}{ Existing Projects } & \\
\hline & & & & & Tuff & Granite & Shale & other \\
\hline
\end{tabular}

tSee Section 2.2 .3$, p. 27

* See Section 2.4 .1 , p. 91 
Table 2.2 (cont.)

ELEMENT 5 (cont.)

Project: 5.5 (OXYGEN GETTERS)

Title: Perform tests on appropriate oxygen getters in backfill host rocks.

Priority: B See Project 5.4.

Justification: Need to find means of combating problems cited in Project

Effort: : FTE p.a. - 0.5; Duration - 2 years :

Expected Results: A method for removing excess oxygen after repository closure will be identified.

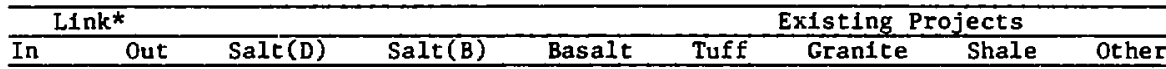

$5.47 .15 \quad 103 ?$

tSee Section 2.2.3, p. 27

*See Section 2.4.1, P. 91 
Table 2.2 (cont.)

ELEMENT 5. (cont.)

\section{Project: 5.6 (SURFACE AREA AND ADSORPTION)}

Title: Develop a mears of measuring surface area that relates to Iadionuclide sorption.

Priority: C Successful accomplishment of this project would permit an easy way of characterizing barrier materials, thereby faclititating site characterization and selection.

Justification: Host traditional methods of measuring surface area yleld results that show a very poor coselaticn with radionuclide sorption. A better method must be found.

Expected Results: A simple and effective technique will be identified for measuring surface area in the laboratory and in the field that shows a good correlation with radionuclide adsorption.

Effort : FiE p.a. - 1.5; Duration -2 years

Notes: This project should be run in conjunction with Project 4.1 .

\begin{tabular}{lllllllll}
\hline \multicolumn{2}{c}{ LInk* } & & & & \multicolumn{3}{c}{ Existing Projects } \\
\hline In & Out & Salt(D) & Salt(B) & Basalt & Tuff & Granite & Shale & Other \\
4.1 & 7.7 & $55 ?, 58 ?$ & 3 & & & $55 ?, 58 ?$ & $1 ?, 54 ?$
\end{tabular}

tSee Section $2.2 .3, \mathrm{p} .27$

*See Section 2.4 .1 , p. 91 
Table 2.2 (cont.)

\section{ELEMENT 6. CHEMICAL TRANSPORT ALGORITHMS}

\section{Aqueous-Solution/Solld-Phese Equilibriun Models}

\section{Project: 6.1 (SOLUTION ALGORITHM)}

Title: Develop an aqueous solution algortthm capable of incorporating all major groundwater conponents and sultable for modeling barriermediun/_queous-phase interactions co $300^{\circ} \mathrm{C}$. If possible, lonic strengths should be modeled between 0 and 5 . Solld phases in equilibrium with the aqueous phase should also be modeled.

Priority: A Without the capability of modeling aqueous-phase chemistry and its relationship to coexisting solid phases, there would be no means of predicting radionuclide wigration through the barriers of the repository system.

Justification: This algorithm is necessary to predict the dissolution of barrier materials when subjected to thermal regimes in a repository.

Expected Results: A chemical algorithm suitable for modeling groundwater Interactions will be developed, in which thermodynamic equilibrium between aqueous species and solid phases is assumed.

Effortt: FTE p.a. - 3; Duration - 3 years

Notes: Many algorithms have already been developed, but further refinement is necessary. A stumbling block is lack of adequate thermodynamic data.

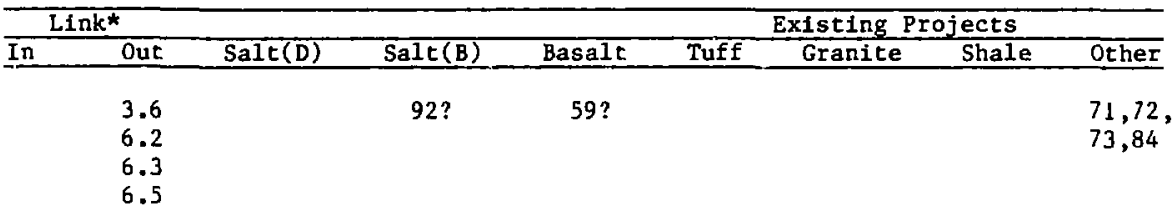

tSee Section 2.2.3, p. 27

*See Section 2.4.1, p. 91 
Table 2.2 (cont.)

ELEMENT 6. (cont.)

Aqueous-Solution/Solld-Phase Equilibrium Models (cont.)

Project: 6.2 (SOLUTION ALGORITHM DATA INPUT)

Title: Incorporate thermodynamic data on solld phases and aqueous species in the aqueous-solution algorithm.

Priority: A See Project 6.1.

Justification: Relevant thermodynamic data must be incorporated to make effective studies of aqueous-phase barrier interactions.

Effort $\dagger$ : FTE p.a. - 3; Duration - 1 year

Expected Results: Data will be incorporated in a chemfcal algorithm capable of modeling groundwater interactions in which thermodynamic equilibrium between aqueous spectes and solld phases is assumed.

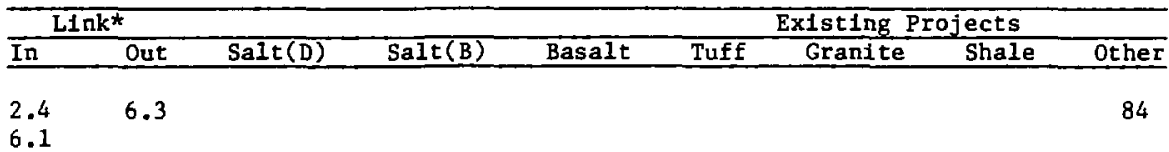

tSee Section 2.2 .3 , p. 27

*See Section 2.4.1, p. 91 


\author{
Table 2.2 (cont.) \\ ELEHENT 6. (cont.) \\ Aqueous-Solution/Solid-Phase Equilibriue Models (cont.)
}

\title{
Project: 6.3 (RADIONUCLIDE DATA INPUT)
}

Title: Incorporate in the algorithm developed under Project 6.1 aqueous speciation and solid phases of relevent radionuclide elenents, including organic constituents. The system should be modeled at temperatures to $175^{\circ} \mathrm{C}$.

Priority: A This project is necessary to permit predictions of radionuclide transport through the barriers of a repository. Without this, it will not be possible to predict repository effectiveness in containing radionuclides.

Justification: Radionuclide data must be incorporated to calculate maximum expected concentrations and speciation of radionuclides coexisting with solid phases. Such information is required to estimate maximum fluxes of radionuclides and to ald in the design of laboratory and field studies and their subsequent interpretation.

Expected Results: A chemical algorithm will incorporate data suitable for predicting the equilibrfum behavior of radionuclides in the aqueous phase in coexistence with solid phases and in the presence of harrier materlals.

Effort ${ }^{\dagger}$ :TTE p.a. - 2; Duration - I year

Notes: Success of this phase of development depends on the availabilfty of suttable thermodynamic data.

\begin{tabular}{|c|c|c|c|c|c|c|c|c|}
\hline \multicolumn{2}{|c|}{ Link* } & & & & \multicolumn{4}{|c|}{ Existing Projects } \\
\hline In & Out & Salt (D) & Salt (B) & Basalt & Tuff & Granite & Shale & Other \\
\hline $\begin{array}{l}2.1 \\
2.3 \\
2.5 \\
2.6 \\
4.9 \\
4.10 \\
6.1 \\
6.2\end{array}$ & $\begin{array}{l}6.4 \\
6.5\end{array}$ & & & & & & & $17 ?, 84$ \\
\hline
\end{tabular}

tSee Section 2.2.3, p. 27

*See Section 2.4.1, p. 91 
Table 2.2 (cont.)

ELEMENT 6. (cont.)

Aqueous-Solution/Solid-Phase Equilibriue Models (cont.)

Project: 6.4 (INCORPORATE ADSORPTION TO $175^{\circ} \mathrm{C}$ )

Title: Incorporate radionuclide adsorption (1ncluding organics) to

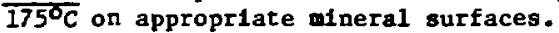

Priority: A See Project 6.3.

Justification: Reversible adsorption is currently assumed to be the principal mechanism that will cause retardation of radionuclides during transport. Algorithms describing adsorption are needed for the design and interpretation of laboratory and field studies.

Expected Results: An adsorption model will be incorporated in the chemical algoriehm.

EFfortt: FTE p.a. - 1; Duration - 1 year

Notes: Suitable models may already exist, but thermodynamic data are lacking. This project may start upon completion of first phase of Project 6.1 .

\begin{tabular}{|c|c|c|c|c|c|c|c|c|}
\hline \multicolumn{2}{|c|}{ Link* } & & & & \multicolumn{4}{|c|}{ Existing Projects } \\
\hline In & out & Salt(D) & Salt(B) & Basalt & Tuff & Granite & Shale & Other \\
\hline $\begin{array}{l}4.1 \\
4.2 \\
4.3 \\
4.4 \\
6.3\end{array}$ & 6.5 & & & & & . & & $1,84 ?$ \\
\hline
\end{tabular}

tSee Section 2.2 .3$, p. 27

*See Section 2.4.1, p. 91 
Table 2.2 (cont.)

ELEMENT 6. (cont.)

Traneport Models Iacorporating Chealcal Algorithas

\section{Project: 6.5 (TRANSPORT ALGORITHM)}

Title: Develop a transport model that incorporates a realistic description of the geometry of the barrier nedium and includes appropriate modifications of the chemical equilibrium algorithms described above.

Priority: A See Project 6.3.

Justification: Such a model must be developed to provide insight into controlling mechanisms and to serve as the basis for confirmatory laboratory and fleld studies over realistic time spans.

Expected Results: A transport model that is consistent with laboratory and field observations will be obtained.

Effortt: FTE p.a. - 3; Duration - 2 years

Notes: Efforts to accomplish these obfectives are underway, but have deficiencies. This project can start upon development of codes under Projects 6.1 and 6.4 .

\begin{tabular}{|c|c|c|c|c|c|c|c|c|}
\hline \multicolumn{2}{|c|}{ Link* } & & & & \multicolumn{3}{|c|}{ Existing Projects } & \\
\hline$\overline{I n}$ & Out & Salt(D) & $\operatorname{Salt}(B)$ & Basalt & Tuff & Granite & Shale & Other \\
\hline $\begin{array}{l}2.2 \\
3.6 \\
6.1 \\
6.3 \\
6.4\end{array}$ & $\begin{array}{l}6.6 \\
6.8 \\
6.9 \\
6.10 \\
6.11 \\
6.12 \\
6.13 \\
6.14 \\
6.15 \\
7.13 \\
7.14\end{array}$ & 62 & $\begin{array}{l}55 ?, 62, \\
92 ?\end{array}$ & & & 95 & $55 ?$ & $\begin{array}{l}60,61, \\
63,70 ?, \\
72\end{array}$ \\
\hline
\end{tabular}

tSee Section $2.2 .3, p .27$

*See Section 2.4.1, p. 91 


\section{Table 2.2 (cont.)}

ELEMENT 6. (cont.)

Traneport Hodels Incorporating Chenical Algorithes (cont.)

\section{Project: 6.6 (INCORPORATE DIFFUSIVITIES)}

Title: Develop a chemical transport model based on that of Project 6.4 , which incorporates diffusivities of relevant complexes as a function of temperature.

\section{Prlority: A See Project 6.3.}

Justification: Diffusion is the dominant transport mechanism in the engineered barrier region. Diffusivities of individual species must be incorporated in chemfcal transport models for accurate simulations.

Effort

Expected Results: A transport model sultable for approximating chemlcal reactions and transport in the engineered barrter region will be obtalned.

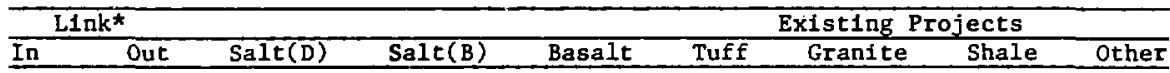

$3.1 \quad 6.7$

tSee Section 2.2.3, p. 27

*See Section 2.4.1, p. 91 
Table 2.2 (cont.)

ELEMENT 6. (cont.)

Transport Models Incorporating Chemical Algorithes (cont.)

Project: 6.7 (INCORPORATE CROSS DIFFUSIONAL COUPLING)

Title: Incorporate cross diffusional coupling and coupling of mass and thermal fluxes in the chemical transport model developed under Project 6.5 .

Priority: C If this phenomenon proves to be statistically significant, it should be incorporated in the radionuclide transport model. See also Project 6.3 .

Justification: Both chemical composition and chemical and thermal gradients will affect d 1 fEusion rates of lons. For accurate modeling, such processes should be incorporated in chemical transport models.

Effort : FTE p.a. - 2; Duration - 2 years

Expected Results: A model suitable for simulating chenical reactions and transport in the engineered barrier region will be obtained.

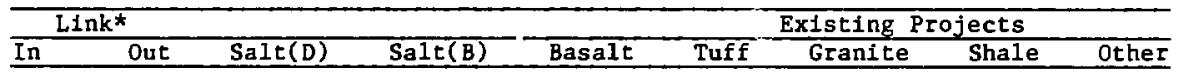

$3.4 \quad 7.14$

6.6

tSee Section $2.2 .3, p .27$

* See Section 2.4.1, p. 91 
Table 2.2 (cont.)

ELEKENT 6. (cont.)

Iransport Modals Incotporating Chenicsl Algorithes (cont.)

PROJECT: 6.8 (INCORPORATE COLLOID TRANSPORT)

Tirle: Incorporate diffusional and/or convective transport of collo1ds, peeudocolloids, and particulates In appropriate transport model.

Priorfty: C If diffusion and/or convective transport of collolds proves to be significant, it should be incorporated in the transport model.

Justification: If colloids, pseudocollotds, or particulates prove to be significant in the transport of radionuclides through barrier media, their transport should be modeled and then tested against laboratory and fieli experiments.

Effortt: FTE p.a. - 1; Duration - 1 year

Expected Results: A model capable of simulating collold, pseudocollold, and particulate transport will be obtained.

\begin{tabular}{|c|c|c|c|c|c|c|c|c|}
\hline \multicolumn{2}{|c|}{ LInk* } & & & & \multicolumn{4}{|c|}{ Existing Projects } \\
\hline In & Out & Salt(D) & Salt(B) & Basalt & Tuff & Grantte & Shale & Other \\
\hline $\begin{array}{l}6 . \\
6.8 \\
7 .\end{array}$ & 7.14 & & & & & & & \\
\hline
\end{tabular}

tSee Section 2.2.3, p. 27

*See Section 2.4.1, p. 91 
Table 2.2 (cont.)

ELEFENT 6. (cont.)

Transport Models Incorporating Chemical Algorithns (cont.)

Project: 6.9 (INCORPORATE ORGANIC SORPTION)

Title: Incorporate organic sorption into transport algorithms.

Priority: B If organic sorption proves significant, it should be Investigated in the transport model. See also Project 6.3.

Justification: Organic sorption may play a significant role in retarding radionuclides.

Effort : FTE p.a. - 1; Durat1on - 1 year

Expected Results: A quantitative assessment of the effect of organics in transporting radionuclides will be obtained.

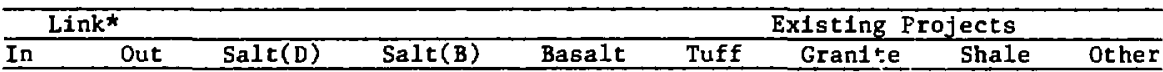

$4.3 \quad 6.10$

6.5

6.8

tSee Section 2.2 .3$, p. 27

*See Section 2.4.1, P. 91 
Table $2.2^{\circ}$ (cont.)

ELIterI 6. (cont.)

Transport Model Incorporating Chemical Algorithns (cont.)

Project: 6.10 (INCORPORATE GRAIN BOUNDARY AND VOLUNE DIFFUSION)

Title: Incorporate grain boundary and voluwe diffusion of radionucl ides and nodels describing long-tern chemtcal changes in mineral surfaces.

Priority: A Subject phenomena will have a significant impact on radionuclide retardation. The phenomena must be incorporated in the transport model so that radionuclide retardation through the barrier system may be predicted.

Justification: These phenomena may be significant over the long time spans during the transport of radionwildes. Their impact on radionuclide retardation should be factored into transport models.

Effort : FTE p.a. - 1; Duration - 2 years

Expected Results: The relative significance of grain boundary and volume diffusion and long-term changes in chemical surfaces will be assessed.

\begin{tabular}{|c|c|c|c|c|c|c|c|c|}
\hline \multicolumn{2}{|c|}{ LInk* } & \multirow[b]{2}{*}{ Sal t (D) } & \multirow[b]{2}{*}{ Sal t (B) } & \multirow[b]{2}{*}{ Basal t } & \multicolumn{3}{|c|}{ Existing Projects } & \\
\hline In & Out & & & & Turf & Granite & Shale & Other \\
\hline
\end{tabular}

$4.5 \quad 7.14$

4.6

4.8

6.5

6.9

tSee Section 2.2 .3$, p. 27

*See Section 2.4.1, p. 91 
Table 2.2 (cont.)

ELEMENT 6. (cont.)

Transport Model s Incorporating Chemical Algorithms (cont.)

Project: 6.11 (INCORPORATE PRESSURE EFFECTS)

Title: Incorporate in an appropriate transport model the effect of pressure and temperature on porosities and permeabilities of backfill materials (includes brine migration in salt).

Priority: B These effects should be incorporated to predict radionuclide transport through the backfill barrier of a repository.

Justification: Long-term changes in the physical properties of engineered barrier media wlll affect radionuclide transport. This effect should be taken into account.

Effortt: FTE p.a. - 1; Duration - 2 years

Expected Results: A model capable of simulating long-term changes in the physical properties of engineered barriers and the impact on radionuclide migration will be obtained.

\begin{tabular}{|c|c|c|c|c|c|c|c|c|}
\hline \multicolumn{2}{|c|}{ IInk* } & & & & \multicolumn{3}{|c|}{ Existing Projects } & \\
\hline In & Out & Sal t (D) & Salt (B) & Basal $t$ & Tuff & Granite & Shale & Other \\
\hline $\begin{array}{l}5.2 \\
6.5\end{array}$ & 7.14 & 35,39 & 35,39 & & & & & \\
\hline
\end{tabular}

tSee Section 2.2 .3 , p. 27

*See Section 2.4.1, p. 91 
Table 2.2 (cont.)

ELEMENT 6. (cont.)

Application of Chemical Transport Models

Project: 6.12 (TREAT CANISTER ARRAYS AND LAYERED MEDIA)

Ticle: Modify existing computer codes or develop new ones that can treat arrays of canlsters as well as transport through mul tilayered media.

Priority: B This is needed to predict radionuclide transport.through multiple barriers of a repository.

Justification: Simple cases lack flexibility in dealing with more complex repository geometry. Codes must be developed to deal with these.

Effort: FTE p.a. - 1.5; Duration - 2 years

Expected Results: Codes capable of modeling In two or three dimensions with more complex boundary sonditions will be produced.

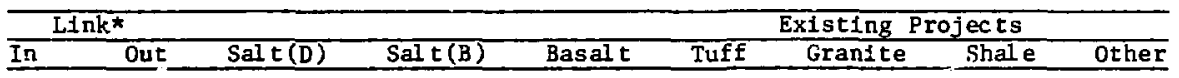

$6.5 \quad 7.14$

tSee Section 2.2 .3$, p. 27

*See Section 2.4.1, p. 91 
Table 2.2 (cont.)

ELEMENT 6. (cont.)

Appl ication of Chemical Transport Models (cont.)

\section{Project: 6.13 (INCORPORATE SPECIAL SOURCE TERMS)}

Title: Modify existing computer codes to incorporate special source term conditions such as collold formation through the degradation of highlevel wastes or transport following disappearance of the source term.

Priority: B This is needed to predict radioactive waste transport through a repository barrier system.

Justification: Current computer codes are not adequate to model special conditions and would require nodification to accommodate them. Such conditions may be 1 m jrtant in predicting long-term repository behavior.

Effort

Expected Results: Modified codes capable of dealing wisil these special conditions will be produced.

\begin{tabular}{|c|c|c|c|c|c|c|c|c|}
\hline \multicolumn{2}{|c|}{ Link* } & & & & \multicolumn{4}{|c|}{ Exiscing Projects } \\
\hline In & Out & Salt (D) & Sal t (B) & Basalt & Tuff & Granite & Shale & other \\
\hline $\begin{array}{l}2.7 \\
2.8 \\
6.5\end{array}$ & 7.14 & & $65 ?$ & & & & & $18 ?$ \\
\hline
\end{tabular}

tSee Section $2.2 .3, p .27$

*See Section 2.4 .1 , p. 91 
Table 2.2 (cont.)

ELEMENT 6. (cont.)

Labnratory Vertfication

\section{Project: 6.14 (LABORATORY VERIFICATION OF TRANSPORT MODELS)}

Title: Chemical transport models shoul $d$ be verified using dynamic column expsriments.

Priorfty: A It is essential to verify transport models, as these will be the only means of predicting long-term containment of a multiple barrier repository.

Justification: Dynamic column experiments can be used to interpret nonequilibrium behavior during chemlcal transpoit. Such experiments are required to verify. theoretical and conceptual algoritims of chemical transport processes.

Expected Resilts: Partial verification or otherwise of computer models simulating chemical transport through barrier media will be made.

Effort : FTE p.a. - 4; Duration - 3 years

Notes: This project may start on completion of Project 6.4 .

\begin{tabular}{|c|c|c|c|c|c|c|c|c|}
\hline \multicolumn{2}{|c|}{ Link* } & \multirow[b]{2}{*}{ Salt(D) } & \multirow[b]{2}{*}{ Sal $t(B)$} & \multirow[b]{2}{*}{ Basalt } & \multicolumn{3}{|c|}{ Existing Projects } & \\
\hline In & Out & & & & Tuff & Granite & Shale & Other \\
\hline 6.5 & 7.14 & $38 ?$ & $38 ?$ & 104 & & 50 & & $\begin{array}{r}84 ?, 94 \\
102,104\end{array}$ \\
\hline
\end{tabular}

tSee Section 2.2 .3 , p. 27

*See Section 2.4.1, p. 91 
Table 2.2 (cont.)

ELEMENT 6. (cont.)

Laboratory Verification (cont.)

Project: 6.15 (CHEMICAL ACCUMULATION OF FISSILE ISOTOPES)

Title: Model conditions to test for the chemical feasibllity of the accumulation of fissile isotopes in geologic and backfill materials adjacent to the canister.

Priority: C As a precaution, this study should be undertaken in the event that fissile isotopes may concentraie and go critical.

Justification: Al though unlikely, the possibllity of radionuclides accumulating to produce a critical mass has not been ruled out. Model !ng will help establish whether such a condition is likely

Expected Results: Conditions will be Identifled where c iticality might arise.

Effort : FTE p.a. - 1; Duration - 2 years

Notes: No foll ow-up research has been incorporated in the plan.

\begin{tabular}{|c|c|c|c|c|c|c|c|}
\hline & & & & & & kisting Projects & \\
\hline$\overline{\mathrm{In}}$ & Out & Sal t (D) & Salt (B) & Basal t & Tuff & Grantte shale & other \\
\hline
\end{tabular}

$6.5 \quad 7.14$

tSee Section 2.2 .3 , p. 27

*See Section 2.4.1, p. 91 
Table 2.2 (cont.)

elEMENT 7. FIELd eValuations

Chareter1zation of Host Rocks and Groundwater

Project: 7.1 (ORGanICS IN GROUNDHATERS)

Title: Ideatify amount and nature of dissol ved organic constitueats in groundwater.

Priority: B If organic compounds enhance radionuclide transport, then repository sites should be selected where organic concentrations are minimal or absent. (See al so Justification, below.)

Justification: Such a study is needed to establish the significance of organic components in groundwater and their ability to transport radionuclides.

Effort t: FTE p.a. -1 ; Duration -2 years

Expected Results: The 1mpact or otherwise of organic components on radionuclide transport will be established.

\begin{tabular}{|c|c|c|c|c|c|c|c|c|}
\hline \multicolumn{2}{|c|}{ Link* } & & & & \multicolumn{4}{|c|}{ Existing Projects } \\
\hline In & Out & Salt (D) & Salt $(B)$ & Basalt & Tuff & Grantte & Shale & Other \\
\hline & $\begin{array}{l}2.5 \\
2.6\end{array}$ & & $9 ?, 15 ?$ & 10 & & & & \\
\hline
\end{tabular}

tsee Section 2.2 .3 , p. 27

*See Section 2.4 .1 , p. 91 
Table 2.2 (cont.)

ELEMENT 7. (cont.)

Characterization of Host Rocks and Grondwater (cont.)

\section{Project: 7.2 (COLLOIdS IN GROUNDhateRs)}

Ticle: Determine the concentration, size, distribution, and, migration properties of colloidal and particulate material in groundwaters.

Priority: C If colloids or particulates enhance radionuclide transport, then sites with minimal concentration of these should be selected. (See al so Justific ation, below).

Jistification: The quantities of collodial and particulate material in groundwater are not well known. This must be recified.

Effortt: FTE p.a. - 1; Duration - 2 years

Expected Resul ts: Concentrations of colloids and particulates in groundwater wfll be determined.

\begin{tabular}{|c|c|c|c|c|c|c|c|}
\hline Link* & & & & \multicolumn{4}{|c|}{ Existing Projects } \\
\hline Out & Salt (D) & Sal t (B) & Basalt & Tuff & Granite & Shale & Other \\
\hline
\end{tabular}

7.3

tSee Section 2.2.J, p. 27

*See Section 2.4.1, p. 91 
Table 2.2 (cont.)

ELEMENT 7. (cont.)

Characterization of Host Rocks and Groundwater (cont.)

\section{Project: 7.3 (CHEMISTRY AND MINERALOGY OF COLLOIDS)}

Title: Evaluate the mineralogy and chemistry of suspended colloids and particulates found in groundwaters.

Priority: C Such information may contribute to predicting radionuclide transport through repository barriers.

Justification: If suspended collolds and particulaces are significant, these should be characterized as a basis for establishing their radionuclide carrying properties.

Effort : FTE p.a. - 1; Duration - 1 year

Expected Resul ts: Description of the mineralogy and chemistry of suspended collofdal and particulate material will be obtained.

\begin{tabular}{lllllllll}
\hline \multicolumn{2}{c}{ Link* } & & & & \multicolumn{2}{c}{ Existing Projects } \\
\hline In & Out & Salt (D) & Salt (B) & Basalt & Tuff & Granite & Shale & Other \\
7.2 & 6.8 & & & & $17 ?$
\end{tabular}

tSee Section 2.2 .3 , p. 27

*See Section 2.4 .1 , p. 91 
Iable 2.2 (cont.)

ELEMENT 7. (cont.)

Characterization of Host Rocks and Groundwater (cont.)

Project: 7.4 (MULTIPLE APPLICATION OF DATING TECHNIQUES)

Title: Continue research on the multiple application of several dating techniques to get better insight into the value of each technique.

Priority: B An independent means of estimating groundwater flow in hydrologic systems is required so that the selection of a repository site can be justified.

Justification: Multiple redundant groundwater dating techniques are needed in order to el iminate uncertainties in estimating groundwater ages .

Effort : FTE p.a. - 3; Duration - 4 years

Expected Results: Refined techniques in dating groundwaters will be developed.

\begin{tabular}{|c|c|c|c|c|c|c|c|c|}
\hline \multirow{2}{*}{\multicolumn{2}{|c|}{$\frac{\text { Link* }}{\text { In Out }}$}} & & & & \multicolumn{4}{|c|}{ Exiscing Projects } \\
\hline & Out & Sal $t(D)$ & Sal c(B) & Basal t & Tuff & Granite & Shale & Other \\
\hline
\end{tabular}

tSee Section 2.2 .3 , p. 27

* See Section 2.4 .1 , p. 91 
Table 2.2 (cont.)

ELEMENT 7. (cont.)

Characterization of Host Rocks and Grounduater (cont.)

Project: 7.5 (GROUNDWATER CHEMISTRY AND AGE MEASUREMENTS)

Title: Deterwine whether changes in groundwater chemistry affect age measurements.

Priority: B See Project 7.4 .

Justiflcation: Possible sources of error in groundwater-age measurements must be detected and eliminated.

Effort t: FTE p.a. - 2; Duration -1 year

Expected Results: Parameters affecting apparent groundwater ages will be Identifled.

\begin{tabular}{|c|c|c|c|c|c|c|c|c|}
\hline \multicolumn{2}{|c|}{ L1nk* } & & & & \multicolumn{4}{|c|}{ Existing Projects } \\
\hline In & out & Salt (D) & Sal t (B) & Basalt & Tuff & Granite & Shale & Other \\
\hline & 7.6 & & & 25 & & $7 ?$ & $7 ?$ & $\begin{array}{l}6 ?, 56, \\
57,100 \\
101\end{array}$ \\
\hline
\end{tabular}

tSee Section 2.2.3, p. 27

*See Section 2.4.1, p. 91 
Table 2.2 (cont.)

EILEMNT 7. (cont.)

Characterfation of Host Rocks and Groundwater (cont.)

Project: 7.6 (DATING TECHNIQUES TO DETECT LOH-VOLUME, HIGH-VELOCITY haTER)

Title: Use water-dating techniques to detect low-volune, high-velocity paths through otherwlse slow-moving groundwater systems.

Priority: B See Project 7.4.

Justification: Groundwater flow in fractured rccks may be nonuniform. Methods to deterwine the magnitude of such effects are required.

Effortt: FTE p.a. - 2; Duration - 2 years

Expected Results: New techniques to observe heterogeneities in groundwater flow will be developed.

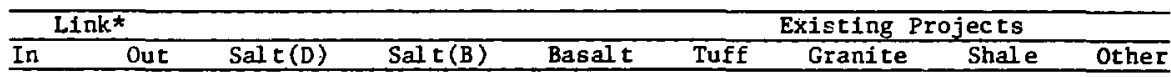

7.4

57 ?

7.5

tSee Section 2.2.3, p. 27

*See Section 2.4.1, p. 9 I 
Table 2.2 (cont.)

ELEYENT 7. (cont.)

Churacterization of Host Rocks and Groundwater (cont.)

Project: 7.7 (CHEHISTRY AND MINERALOGY OF SITE SPECIFIC AQUIFERS)

Title: Chemistry and wineralogy of site specific aquifer surfaces in the near and far field should be characterized.

Priority: C The information obtained from this study would aid in refining predictions of radionuclide transport at a particular site and thereby influence site selection.

Justification: Information is needed to refine predictions of radionuclide migration at a particular site.

Effort : FTE p.a. - 1; Duration - 1 year

Expected Resul ts: Surfaces will be characterized in tertas of parameters needed to predict radionuclide migration.

\begin{tabular}{|c|c|c|c|c|c|c|c|c|}
\hline \multicolumn{2}{|c|}{ Link* } & \multirow[b]{2}{*}{ Salc(D) } & \multirow[b]{2}{*}{ Sal $c(B)$} & \multirow[b]{2}{*}{ Basalt } & \multicolumn{3}{|c|}{ Existing Projects } & \multirow[b]{2}{*}{ other } \\
\hline In & Out & & & & Tuff & Granite & Sha!e & \\
\hline 5.5 & & $27 ?$ & $\begin{array}{l}8,9, \\
11 ?, 32, \\
33,58, \\
64\end{array}$ & $\begin{array}{l}3 ?, 25, \\
34\end{array}$ & $\begin{array}{l}26,29 ? \\
30 ?\end{array}$ & $\begin{array}{l}7,10, \\
30 ?\end{array}$ & 7,23 & $\begin{array}{l}6,16, \\
18 ? \\
31 \text { (anhydrite) }\end{array}$ \\
\hline
\end{tabular}

tSee Section $2.2 .3, \mathrm{p} .27$

*See Section 2.4.1, p. 91 
Table 2.2 (cont.)

ELEENT 7. (cont.)

Testing

Project: 7.8 (GROUNDWATER SAMPLE PROCUREMENT)

Title: Test groundwater sampl ing and analys1s (e.g., Eh) techniques in the field to determine whether uncontaminated sample procurement is feasibìe.

Priority: B See Project 1.2 .

Justification: Uncontaminated samples are necessary for baseline studies and hydrological interpretations.

Effort : FTE p.a. - 2; Duration - 1 year

Erpected Results: Sampling and field analysis techniques will be st:andardized.

\begin{tabular}{|c|c|c|c|c|c|c|c|c|}
\hline \multicolumn{2}{|c|}{ Lnk* } & & & & \multicolumn{4}{|c|}{ Existing Projects } \\
\hline In & Out & Sal t(D) & Salt (B) & Basalt & Tuff & Granite & Shale & Other \\
\hline $\begin{array}{l}1.2 \\
1.3\end{array}$ & & , & & $34 ?$ & & & & $\begin{array}{l}16 ?, 93, \\
96,99 ? \\
100 ?\end{array}$ \\
\hline
\end{tabular}

tSee Section 2.2 .3 , p. 27

*See Section 2.4.1, p. 91 
Table 2.2 (cont.)

ELEYENT 7. (cont.)

Testing (cont.)

Profect: 7.9 (TEMPORAL VARIATIONS IN GRADIENTS)

Title: Evaluate temporal varlations in hydraulic, thermal, and chemical gradfents adjacent to a thermal source simulating canister emplacement.

Priority: A See Projects 1.1 and 5.2.

Justification: Information is necessary to interpret radionuclide migration through engineered barriers.

Expected Results: Quantitative data on parameters needed for evaluation of radionuclides through engineered barrfers will be obtained.

Effortt: FTE p.a. - 2; Duration - 4 years

Notes: Extensive field support will be required.

\begin{tabular}{|c|c|c|c|c|c|c|c|c|}
\hline \multicolumn{2}{|c|}{ L1nk* } & & & & \multicolumn{4}{|c|}{ Existing Projects } \\
\hline In & Out & Salt (D) & Salt $(B)$ & Basalt & Tuff & Granite & Shale & Other \\
\hline $\begin{array}{l}2.2 \\
5.2 \\
5.3\end{array}$ & 7.14 & & & & & & & 93 \\
\hline
\end{tabular}

tsee Section 2.2 .3 , p. 27

*See Section 2.4.1, p. 91 
Table 2.2 (cont.)

ELEMENT 7. (cont.)

Testing (cont.d)

Project: 7.10 (EFFECT OF TEMPERATURE GRADIENT ON NEAR-FIELD PERMEABILITY)

Title: Measure the effect of temperature gradients on permeability in the near-field region.

Priority: B See Projects 1.1 and 5.2.

Justification: Mass transfer of rock-forming mineral constituents could have a dramatic effect on permeability in the near-field region. This must be determined through field experiments.

Effort : FTE p.a. - 4; Duration - 4 years

Expected Resul ts: The effect of such processes on near-field host rock permeability will be clarified.

Notes: The project does not include construction of a test facllity.

\begin{tabular}{|c|c|c|c|c|c|c|c|c|}
\hline \multicolumn{2}{|c|}{ Link* } & \multirow[b]{2}{*}{ Salt (D) } & \multirow[b]{2}{*}{ Salt(B) } & \multirow[b]{2}{*}{ Basal $\mathrm{C}$} & \multicolumn{3}{|c|}{ Existing Projects } & \multirow[b]{2}{*}{ Other } \\
\hline In & Out & & & & Tuff & Granite & Shale & \\
\hline $\begin{array}{l}2.2 \\
5.3\end{array}$ & 7.14 & $\begin{array}{l}15 ?, 35 ?, \\
38 ?, 46\end{array}$ & $\begin{array}{l}15 ?, 35 ?, \\
38 ?, 41 ?\end{array}$ & $21,22 ?$ & & & $\begin{array}{l}13 ?, 14 \\
43\end{array}$ & $93,9 i$ \\
\hline
\end{tabular}

tSee Section 2.2.3, p. 27

*See Section 2.4.1, p. 91 
Table 2.2 (cont.)

ELEMENT 7. (cont .)

Testing (cont.)

Project: 7.11 (LONG-TERM EFFECTS ON BACKFILL AND HOST ROCKS)

T1tle: Evaluate $1 \mathrm{ong}-t e r m$ effects in physical and chemical properties of backfill and host rocks when subject to temperatures to $300^{\circ} \mathrm{C}$.

Priority: B See Projects 1.1 and 5.2 .

Justification: Changes in physical and chemical properties of backfill and host roks must be evaluated so that their properties with respect to radionuclide migration can be correctly predicted.

Effortt: FTE p.a. - 4; Duration - 4 years

Expected Results: The cherical and physical properties of backfill and host-rock materials as a function of time will be predicted.

Notes: The project does not include construction of a test faciifty.

\begin{tabular}{|c|c|c|c|c|c|c|c|c|}
\hline \multicolumn{2}{|c|}{ Link* } & \multirow[b]{2}{*}{ Salt (D) } & \multirow[b]{2}{*}{ jalt (B) } & \multirow[b]{2}{*}{ Basalt } & \multicolumn{3}{|c|}{ Existing Projects } & \multirow[b]{2}{*}{ Other } \\
\hline In & Out & & & & Tuff & Granite & Shale & \\
\hline $\begin{array}{l}1.1 \\
2.2 \\
3.6 \\
5.2 \\
5.3\end{array}$ & 6.11 & $37 ?$ & $37 ?$ & $\begin{array}{l}21 ?, 22 ?, \\
59 ?\end{array}$ & & & $13 ?, 14$ & $\begin{array}{l}89,90 \\
96\end{array}$ \\
\hline
\end{tabular}

TSee Section 2.2.3, p. 27

*See Section 2.4 .1 , p. 91 
Table 2.2 (cont.)

ELEMENT 7. (cont.)

Testing (cont.)

Project: 7.12 (FIELD TESTS ON BACKFILL AND HOST ROCK ENVIRONMENT)

Title: Perform field tests to characterize the backfill/host rock environment.

Priority: A This stage is essential to allow prediction of the behavior of a given site and establish whether it is acceptable for radioactive waste storage.

Justification: Field testing must be undertaken to ensure that the correct values of parameters are used in predictive models.

Effortt: FTE p.a. - 10; Duration - 2 years

Expected Results: The backfill/host rock environment in tertus of parameters needed for the final design of field studies for radionuclide migration.

\begin{tabular}{|c|c|c|c|c|c|c|c|}
\hline Link* & \multirow[b]{2}{*}{ Salt(D) } & \multirow[b]{2}{*}{ Salt(B) } & \multirow[b]{2}{*}{ Basalt } & \multicolumn{3}{|c|}{ Existing Projects } & \multirow[b]{2}{*}{ other } \\
\hline Out & & & & Tuff & Granite & Shale & \\
\hline 7.13 & $\begin{array}{l}38,46, \\
81\end{array}$ & $38,64 ?$ & 45,49 & $\begin{array}{l}40,50, \\
77\end{array}$ & $\begin{array}{l}42,76, \\
77,78\end{array}$ & $\begin{array}{l}43,75, \\
77\end{array}$ & $\begin{array}{l}16 ?, 44 ?, \\
78,89, \\
90,93, \\
94,96, \\
97\end{array}$ \\
\hline
\end{tabular}

tSee Section 2.2.3, p. 27

*See Section 2.4.1, p. 91 
Table 2.2 (cont.)

ELEMENT 7. (cont.)

Testing (cont.)

Project: 7.13 (FIELD VERIFICATION OF MODELS)

Title: Verify model concepts through fleld testing.

Priority: A See Project 6.14.

Justification: This Important subject must be accomplished to ensure that laboratory, theoretical, and conceptual evaluations of radionucilde Migration are valid in the field.

Expected Resuits: The validity or otherwise of laboratory, theory, and madels will be demonstrated.

Effort: FTE p.a. - 10; Duration - 3 years

Notes: Does not include construction of a test facility. This project should be evaluated in more detall and broken down into subtasks for a better estimate of manpower.

\begin{tabular}{|c|c|c|c|c|c|c|c|c|}
\hline \multicolumn{2}{|c|}{ LInk* } & & & & \multicolumn{4}{|c|}{ Existing Projects } \\
\hline In & Out & Salc(D) & Sal t(B) & Basalt & $\overline{\text { Tuff }}$ & Granite & Shal e & Other \\
\hline $\begin{array}{l}6.5 \\
7.12\end{array}$ & 7.14 & $81 ?$ & 64 & & 50 & $\begin{array}{l}76 ?, 79 ? \\
80 ?\end{array}$ & & $\begin{array}{l}52,53, \\
63\end{array}$ \\
\hline
\end{tabular}

tSee Section 2.2 .3 , p. 27

*See Section 2.4 .1 , p. 91 
Table 2.2 (cont.)

ELEMENT 7. (cont.)

Testing (cont.)

Project: 7.14 (INTÉRPRET FIELD DATA)

Title: Interpretation of ffeld data.

Priority: A This is the final stage in confinming the suitability of a site for radioactive waste storage.

Justification: Data from field experiments must be evaluated to confirm the validity of the transport models upon which the field experiments were based.

Effort : FTE p.a. - 6; Duration - 1 year

Expected Results: The validity or otherwise of laboratory, theory, and models will be demonstrated.

\begin{tabular}{|c|c|c|c|c|c|c|c|c|}
\hline \multicolumn{2}{|c|}{ Link* } & & & & \multicolumn{3}{|c|}{ Existing Projects } & \\
\hline In & Out & Salt (D) & Salt (B) & Basalt & Tuff & Granite & Shale & other \\
\hline $\begin{array}{l}6.5 \\
6.6 \\
6.7 \\
6.8 \\
6.10 \\
6.11 \\
6.12 \\
6.13 \\
6.14 \\
6.15 \\
7.9 \\
7.10 \\
7.13 \\
7.15\end{array}$ & & 27 & $\begin{array}{l}32,58 ? \\
64 ?\end{array}$ & $28,59 ?$ & 29,50 & $76 ?$ & $58 ?$ & $\begin{array}{r}52,53 \\
63,94 ? \\
96 ?, 99 \\
100,102\end{array}$ \\
\hline
\end{tabular}

tSee Section 2.2.3, p. 27

*See Section 2.4.1, p. 91 
Table 2.2 (cont.)

ELEMENT 7. (cont.)

Testing (cont.)

Project: 7.15 (TEST OXYGEN GETTERS)

Title: Field test oxygen getters in backfill.

Prior1ty: B See Project 5.4 .

Justification: Laboratory studies as to the effectiveness and need

for oxygen getters must be verifled.

Effortt: FTE p.a. - 1; Duration - 1 year

Expected Results: Oxygen backfill getters will be successfully demonstrated.

\begin{tabular}{llllll}
\hline \multicolumn{2}{c}{ Link* } & & & Existing Projects & \\
In Out & Salt(D) & Salt(B) Basalt & Tuff Granite Shale Other \\
\hline
\end{tabular}

\subsection{7 .14}

tSee Section $2.2 .3, p .27$

*See Section 2.4.1, p. 91 
It is clear fron perusal of Table 2.2 that, when the prof jsed research is conpared with ongoing research covering the same topics, coverage is uneven and incomplete. However, the greatest difficalty lies in the possibility that ongoing projects are more comprehensive in their scope than is apparent from published project descriptions. Resolving this difficulty will require further discussions with the investigators participating in these projects, and refinemerit of ongoing.project descriptions.

\subsection{SCHEDULE}

\subsubsection{Development of a Schedule}

A schedule of projects necersitates knowing the order in which projects can be implemented. Some projects may be executed concurrently, ochers must be in sequence, the product of one being the input for the succeeding project. Also, one project may require input from several precursors, or the output of one may radiate toward a suite of successors. To facilitate comprehension of the logical sequence, the links are fdentified beneath each project description in Table 2.2. Inputs for some projects are not necessarily required at the start of those projests. In making these links, therefore, some projects have been subdivided into segments to allow for startup prior to receipt of data fron a predecessor.

As a result of several iterations, In which credit was also given to progress being made by current projects, a program was formulated which is illustrated by the schedule chart shown in Figure 2.1. The critical path in this schedule consists of those projects occupying the bottom line of the chart and those stacked immediately above the critical path projects which conform to the same time intervals. It is interesting to note that the critical path contalns of the following major project categories:

\section{Laboratory experiments}

2. Modelling and data Input to the solution algorithm

3. Development of a transport algorithm

4. Field and laboratory verification of transport models

5. Interpretation of field data.

Accomplishment of these critical path projects can be important milestones in attalning the geochemistry research program goals, as will be discussed in the following section.

The schedule Indicates that a conventional research effort ained at elucidating processes in a generic sense would take approximately 16 years. It is possible that the duration could be reduced by as nuch as 20 to 30 percent by adding more manpower. However adjustments ments of this kind may be constrained by the availability of skilled scientists. Furthermore, sone aspects of a geochemistry research program have been obitted. - For example, 


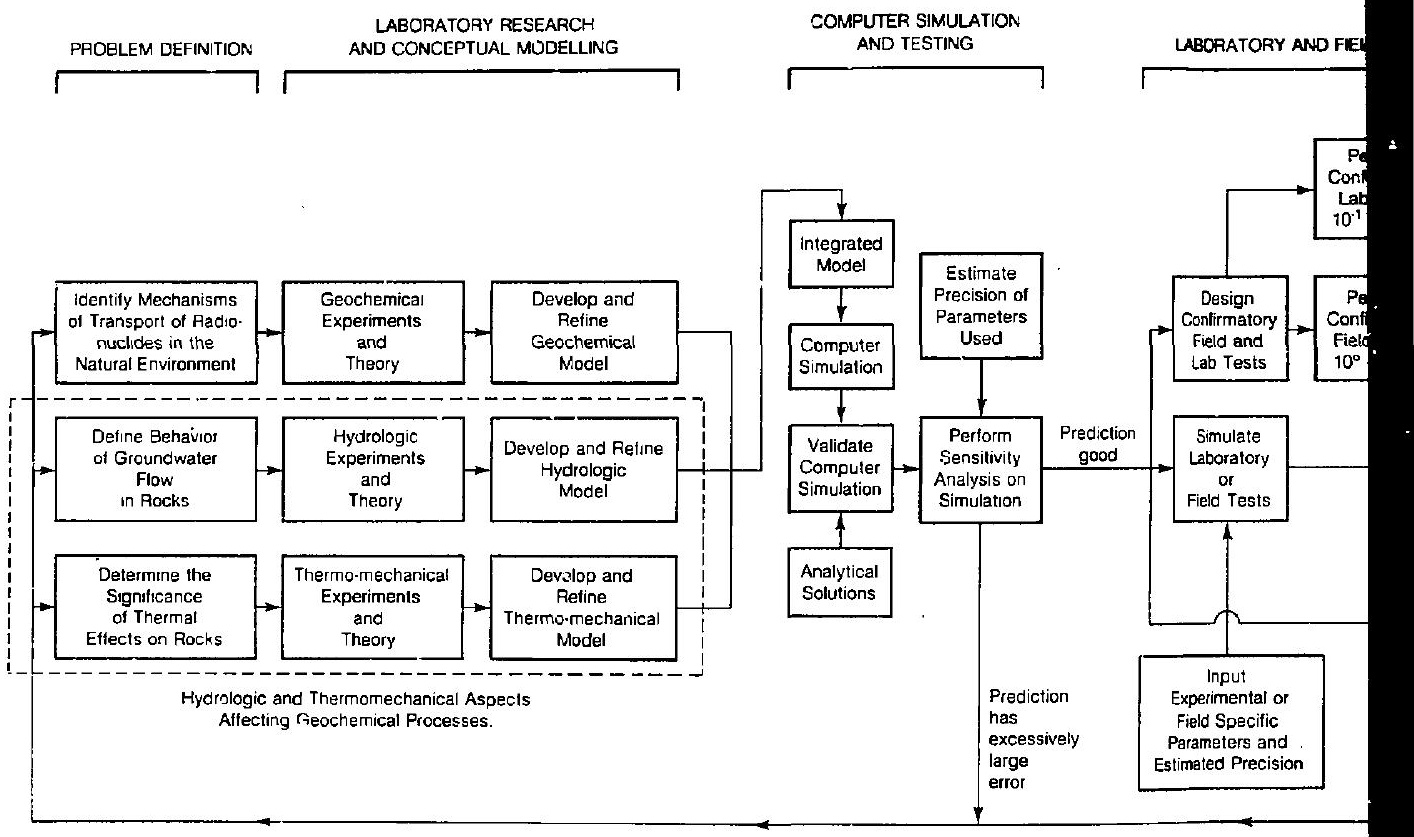

Figure 1.2 Logic chart to identify geochemical needs for th 


\section{Key to Figure 2.1}

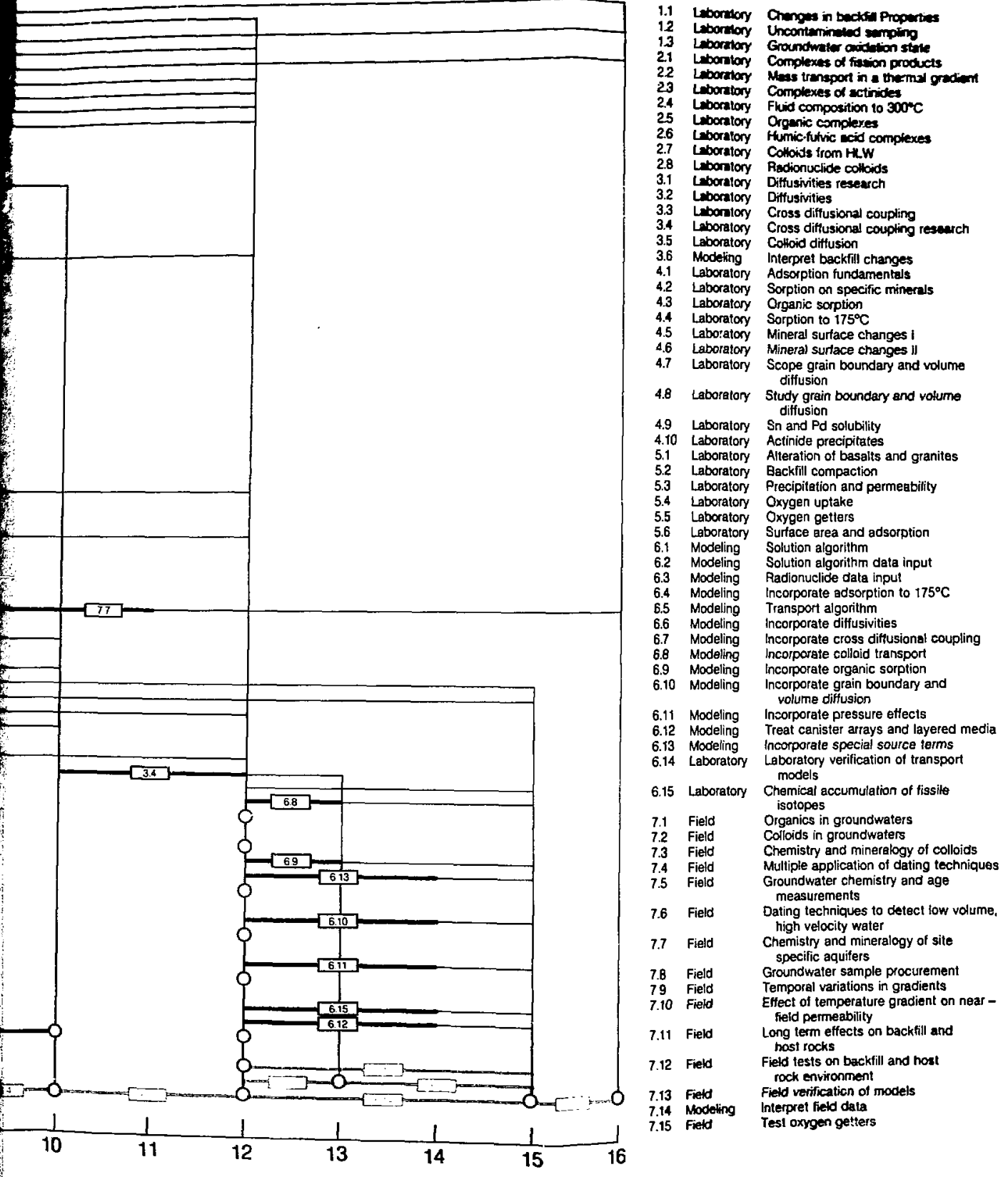


the present progran does not address the effort necessary to characterize specific sites. Nor is research included that could reconcile laboratory and field tudies with natural processes analogous to radioactive waste storage. The overall research effort would therefore be larger than indicated were these ontssions to be taken into account.

Field testing in the research program presented in this report falls Into two categories: (1) that which can be accomplished with drilling alone, and (2) that which requires an underground facility simulating the conditions expected in a repository. Fleld testing falling into the first category is necessary to resolve a number of issues prior to deciding whether to proceed with laboratory research, and should start immediately. In contrast testing requiring a dedicated facility, can only begin once laboratory research and modelling has defined the test program.* Figure 2.1 indicates that testing in a dedicated faclitty could start as early as five years after initiation of the program.

According to the current schedule, field verification of models must take three years. Therefore this phase of the geochemistry research program cannot be completed before fifteen years from the start of the program, to be followed by at least one year of data evaluation and interpretation. Final results and conclusions of the program therefore would not be available until seventeen years after starting the program.

While reviewing the subject of schedules, it is interesting to note the consequence of negative decisions emerging from all research projects whose objectives are to determine whether further research would be required (See 2.4.2, below). Figure 2.2 shows a schedule chart where such is the case. The reduction in scope occurs in laboratory experimental and computer modeling requirements, not in field studies. This program might fairly be described as the minimum possible, although it is quite improbable. Further reductions could not be made without serlously compromising the effectiveness of the present program in meeting its goals.

‡ The study of analogues could be conducted fndependently of both categories of field research. 


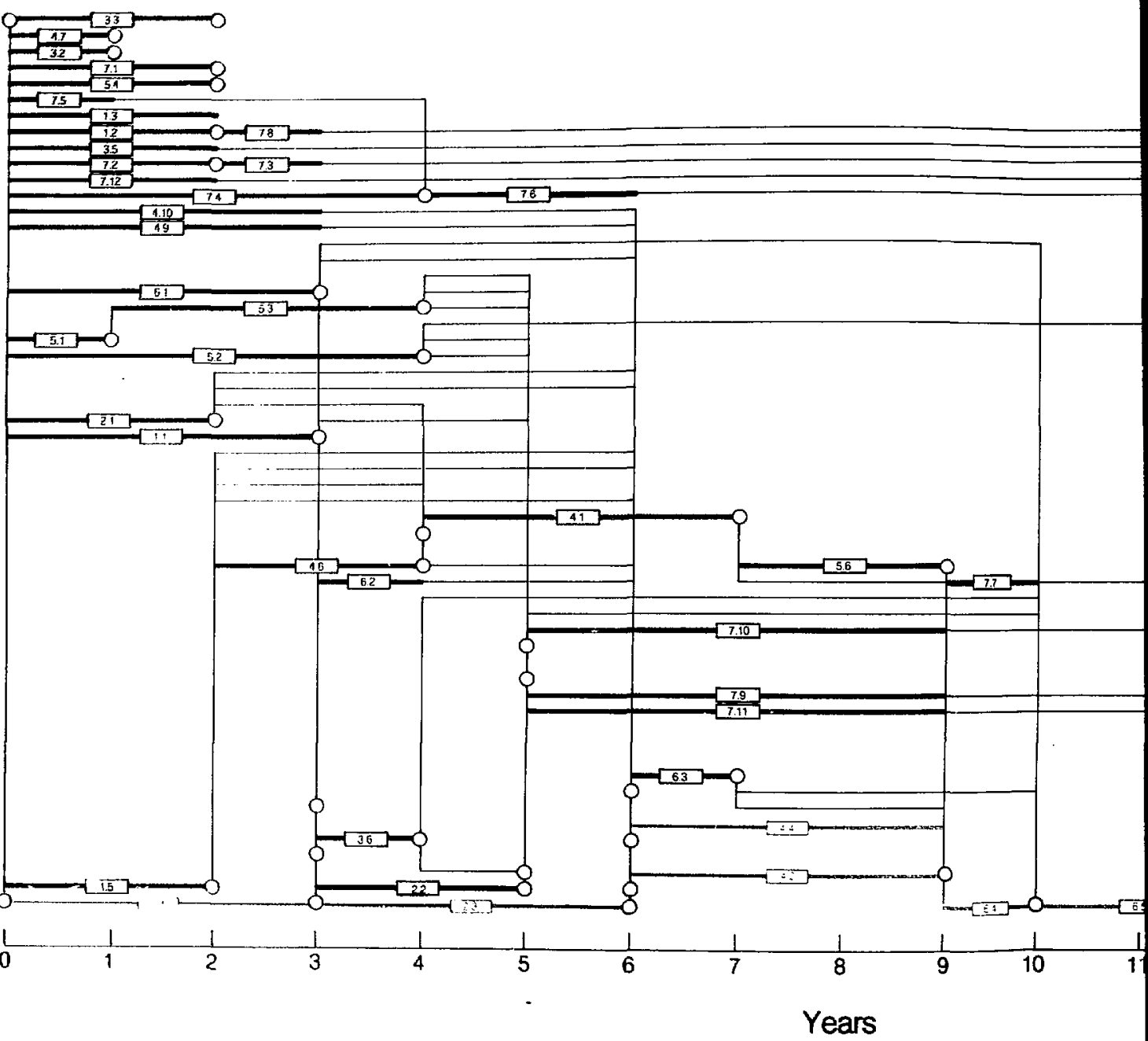

Figure 2.2. Schedule of projects assuming a minimal lev 


\section{Key to Figure 2.2}

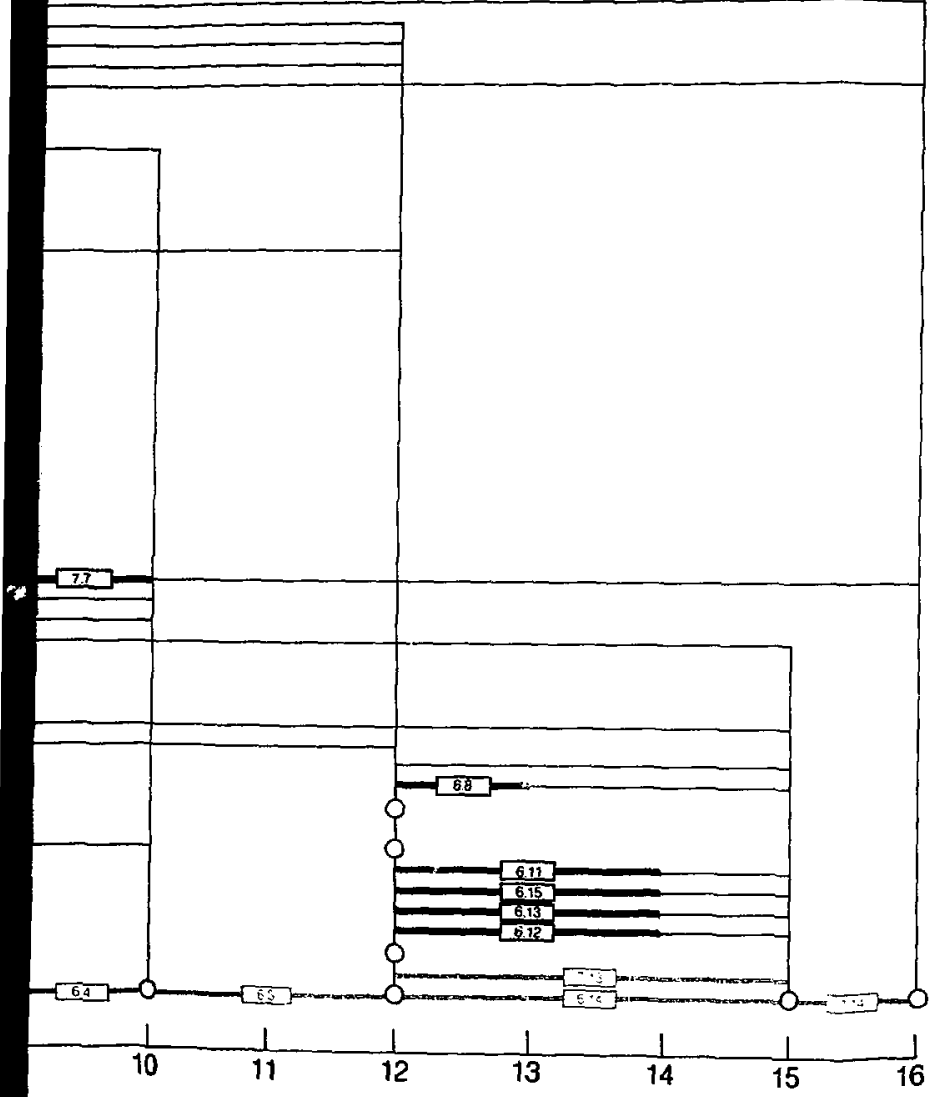

$y$
Laboratory Laboratory

sboratory Laboratory

Laboratory

Laboratory

Laboratory

aboratory

Laboratory

Leboratory

Modeling

Laboratory

Laboratory

Laboratory

Laboratory

Laboratory

Laboratory

Laboratory Laboratory

Laboratory

Laboiatoy

Laboratory

Laboratory

Leboratory

Modeling

Modeling

Modeling

Modeling

Modeling

Modeling

Modeling

Modeling

Modeling

Laboratory

Laboratory

Fiekd

Field

Field

Field

Field

Field

Field

idd

Field

Fiend

Find

Fodeing
Changes in backfill properties Uncontaminated sampling

Groundwater oxidation state

Complexes o* fission products

Mass transport in a thermal gradient

Complexes of actinides

Fluid composition $10300^{\circ} \mathrm{C}$

Diffusivities

Cross diffusional coupling

Collaid diffusion

Interpret backfill changes

Adsorption fundamentals

Sorption on specific minerals

Sorption to $175^{\circ} \mathrm{C}$

Mineral surface changes I

Mineral surface changes it

Scope grain boundary and volume

Sn and Pd solubility

Actinide precipitates

Alteration of basalts and granites

Backfill compaction

Precipitation and permeability

Oxygen uptake

Surface area and adsorption

Solution algorithm

Solution algorithm data input

Redionuclide data input

Incorporate adsorption to $175^{\circ} \mathrm{C}$

Transport algorithm

Incorporate colloid transport Incorporate pressure effects

Treat canister arrays and layered media incorporate special source tems

Laboratory verification of transport models

Chemical accumulation of fissile isotopes

Organics in groundwaters

Colloids in groundwaters

Chemistry and mineralogy of colloids

Multipte application of dating techniques

Groundwater chemistr: and age

measuraments

Dating fechniques to detect low volume,

high velocity water

Chemistry and mineralogy of sito specific aquiters

Groundwater sample procurement

Temporal variations in gredients

Eflect of temperature gradient on near frotd permeability

Long term effects on backfil and host rocks

Field tosts on backfill and host rock environment

Field verification of models

interpret field date 


\section{4 .2 Critical Hilestones}

All projects in the program have stated objectives contributing towards the overall goal of the program. In a sense, completion of each project and satisfactory resolution of that particular problem is a wilestone. However, some milestones are more important than others both in terms of the direction the research program takes, and in contributing to the overall goal of the program.

Accomplishments resulting from completion of a project can be assigned to any of five categories:

1. Results and conclusions that determine whether further research is needed.

2. The acquisition of information that deterwines, defines or limits the scope and objectives of succeeding projects.

3. obtaining data, acquiring information, developing techniques, or constructing equipment as necessary input for the succeeding projects.

4. Results and conclusions confirming tentative accomplishments reached earlier in other projects.

5. Decisions relating directly to the design and construction of a repository.

These categories do not help to identify a heirarchy of milestones meeting the goal of the program. However, In determining the program's magnitude and direction, mllestones under categories 1 and 2 are obviously more influential. Milestones in thes: two categories are Identified below together with the projects that may ultimately be affected. Some milestones are also critical, 1.e. they must be accomplished if the program is to meet its goal. Several of these milestones lie on the critical path. The program milestones and their relationship to associated projects are amplified in the following pages. The titles and numbers of the projects are the same as those given In Table 2.2.

2.4.2.1. M1lestones determining whether further research is required.

1. Project 3.2 (DIFFUSIVITIES)

Determines the significance of variations in magnitude of diffusion coefficients of radionuclide aqueots species. If the magnitude of variations is less than errors introduced by uncertainties in other parameters, then no further research will be needed. Projests affected would be $3.1,3.3$ and 6.6 . 


\section{Project 3.3 (CROss DIfFusional COUPLIHG)}

Deternines the significance of cross diffusional coupling. If this phenomenon is not of sufficlent angitude to exceed estimated errors due to uncertainties of other parameters, then no further research will be needed. Projects affected would be 3.4 and 6.7 .

\section{Project 3.5 (COLLO_D DIFFUSION)}

Determines experimentally whether significant colloid diffusion can occur through rock pores. If not significant, then no further research concerning collold diffusion is required. Projects affected would be 2.7 and 2.8 .

Hote: Colloid transport may never-the-less take place due to convective groundwater movement.

4. Project 4.7 (SCOPE GRAIN BOUNDARY AND VOLUME DIFFUSION)

Determines the significance of grain boundary and volume diffusion mechanisms in retarding radionuclide transport. If not significant, no further research in this area is required. Projects affected would be 4.8 and 4.6 .

5. Project 5.4 (OXYGEN UPTAKE)

Determines whether oxygen uptake in ferrous tron poor rocks could lead to long term persistenc of oxidizing conditions in a reposttory. If this does not appear to be likely, or oxidizirg conditions in a repository are not critical, then no further research on oxygen upcake need be performed. Projects affected would be 5.5 and 7.15 .

6. Code 6.15 (CHEMICAL ACCUNULATION OF FISSILE ISOTOPES)

Determines through modeli ing whether fissile isotopes can accumul ate to produce a critical mass. If resul:s are negative, there is little, if any, incentive to pursue this matter further. No follow up research on this matter has been incorporated in the current geochemistry research program.

7. Project 7.1 (ORganics IN GROUNDWATERS)

Establish the significance of organics in groundwaters. If concentrations are less than sufficient to affect radionuclide migration, then no further research would be required (provided organics are not introduced into a repository with the waste). Projects affected would be $2.5,2.6,4.3$ and 6.9 . 


\subsubsection{Milestones Defining the Scope of Further Research}

\section{Project 2.1 (COMPLEXES OF FISSION PRODUCTS)}

Limits the number of complexes of significant fission products to those likely to be the principal transported forms between 25 and $175^{\circ} \mathrm{C}$. Project affected would be 6.3 .

\section{Project 2.3 (COMPLEXES OF ACTINIDES)}

Limfts the number of complexes of actinides to those likely to be the principal transported forms between 25 and $175^{\circ} \mathrm{C}$. Project affected would be 6.3 .

\section{Project 2.7 (COLLOIDS FROM tLW)}

Determines whether colloids from the decomposi: inn of high level waste are significant carriers of radionuclides. If they are, then colloid transport must be considered in the subsequent transport algorithms. Project affected would be 6.8 .

4. Project 2.8 (RADIONUCLIDE COLLOIDS)

Determines if and when colloids of otherwise insoluble radionuclide species might be produced as a result of supersaturation of radionuclides in the aqueous phase. If the formation of such colloids is significant, then they must be considered in subsequent transport algorithms. Project affected would he 6.8 .

\section{Project 3.6 (INTERPRET BACKFILL CHANGES)}

Identifies and quantifies mechanisms of backfill alteration and thereby determines the nature of transport algorithus used in predicting radionuclide migration (Project 6.5) and the design of field experiments to determine long term effects of backfill interactions. Project affected would 7.11 .

6. Project 4.2 (SORPTION ON SPECIFIC NINERALS)

Identiftes minor phases that could have a major impact on radionuclide retardation, and which must be considered in sorption mechanisms to $175^{\circ} \mathrm{C}$. Project affected would be 6.4 .

7. Project 4.5 (MINERAL SURFACE C: NGES I)

Determines whether short term tests of radionuclide sorption are meaningful and establishes the significance of long tern sorption effects on radionuclide migration. This fll 2imit the scope of several projects. Projects affected would be $4,1-4.4$ and 6.10 .

8. Project 4.6 (MINERAL SURFACE Changes II) As above 
9. Project 4.9 (Sn AND Pd SOLUBILITY)

Determines the relative importance of $\mathrm{Sn}$ and $\mathrm{Pd}$ solution species, their effect on $5 n$ and Pd solubilfties in natural systems, and how they might linit the maximum radionuclide flux of these to insignificant levels. This stucy might limit the imput to the solution algorithm. Project affected would be 6.3 .

10. Project 4.10 (ACTINIDE RRECIPITATES)

Deternines solubilities of actinide precipitates in natural systens and whether they might limit the maximum radionuclide flux to insignificant levels. This stuay may limt the input to the solution algorithm. Project affected would be 6.3 .

\subsubsection{Milestones on the Critical Path}

Frojects on the critical path are summarlzed in Table 2.3.

\section{TABLE 2.3 CRITICAL PATH PROJECTS}

Title

$\begin{array}{lll}1 & 2.4 & \text { FLUID COMPOSITION TO } 300^{\circ} \mathrm{C} \\ 2 & 2.3 & \text { COMPLEXES OF ACTINIDES } \\ 3 & 4.4 & \begin{array}{l}\text { SORPTION TO } 175^{\circ} \mathrm{C} \\ \text { SORPTION ON SPECIFIC MINERALS } \\ 4.2\end{array} \\ 5 & 6.4 & \text { INCORPORATE ADSORPIION TO } 175^{\circ} \mathrm{C} \\ 6 & 6.5 & \text { TRANSPORT ALGORITHM } \\ & 6.6 / 6.7 & \begin{array}{l}\text { INCORPORATE DIFFUSIVITIES/INCORPCRATE CROSS } \\ \text { DIFFUSIONAI COUPLING }\end{array} \\ 7 & 6.14 & \text { LABORATORY VERIFICATION OF TRANSPORT MDDELS } \\ 7.13 & \text { FIELD VERIFICATION OF MODELS } \\ & 7.14 & \text { INTERPRET FIELD DATA }\end{array}$

Some of these projects are of major importance to the program, e.g. $6.14,7.13$ and 7.14 . Others, such as 6.6 and 6.7 may never be implemented, as noted. eariier. Hence, projects on the critical path may change with the evaluation of the program. Those milestones on the critical path, which are deemed important at this time are:

\section{Project 6.5 (TRANSPORT ALGORITHM)}

A transport algorithm incorporating the solution. algorithm from Project 6.1 , is a prerequisice for subsequent confirmatory laboratory and field experiments demonstraring radionuclide transport concepts (Projects 6.14 anc 7.13$)$. In addition, it must be successfully acconplished before further modifications can be incorported (e.g., Projects 6.6-6.13 that represent the outcome of concurrent experimental research. 


\section{Projects 6.14 (LABORATORY VERIFICATION OF TRANSPORT HODELS) 7.13 (FIELD VERIFICATION OF HODELS)}

Completion of these two projects is essential to the success of the program in that they confirm the validity of preceaing research and establish the feasibllity or otherwise of underground radioactive waste storage.

\subsubsection{Overal1 Manpower Requirements}

Figure 2.3 is an example 111 ustrating the manpower requirements for this program. It is assumed by this schedule and the manpower chart that all project activities will be required to complete the program. This is ast necessarily so, as will be discussed below.

Table $2.4 \mathrm{~A}$ shows the breakdown of these manpower requirements by year and by major category of research worker; laboratory experimental ist and interpreter, modeler, and field worker.

The requirements in all three categories fluctuate widely during the colsse of the program. Some smoothing of the workload might be accomplished in the modelling and fiel d experimental categories, but at a risk of jeopardizing the present schedule. Furthermore, smoothing implies a certain flexibility among technical staff which is not always available. In any case, the major question is availability, particularly in laboratory experimental areas. The program, as presently conceived, is overc rowded at the front end. After the fourth year, manpower/requirements tall from an average of 49 FTE pa to an average of $151 / 2$ FTE pa. Finding and directing the efforts of so many skilled scientists familiar with the problem for only four years is likely to strain available resources. However, this number must be used within the period indicated in order to accomplish the program goal within 16 years. Major redistributions of manpower would require a complete restrunting of the research program.

Figure 2.4 gives manpower distribution in the unlikely eventuality that the outcome of projects determining whether future research is required will all give negative answers. A similar problem arises with manpower distribution for this minimal program as indicated in table $2.4 \mathrm{~B}$.

\section{4 .4 Resources}

Resources to accomplish the geochemistry research program can be broken down into manpower and facilities. The facilities for laboratory experimental and modeling studies are available at national laboratories and are expected to be adequate for the projects delineated. Equipnent and facilitjes for handling radioactive substances are readily avallable at these institutions. No 1 aboratory projects in the program require equipment that cannot be readily modified or fabricated in national laboratory shops. 


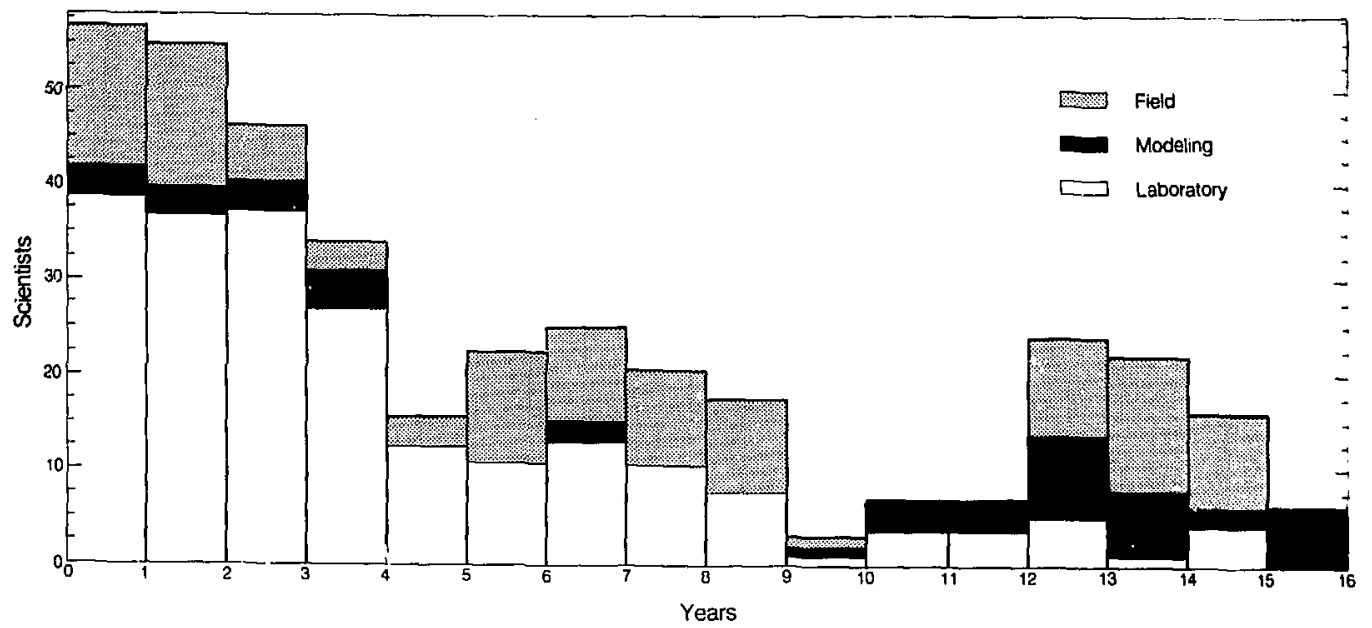

安

Figure 2.3. Manpower requirements for prujects

XEL. 843.9437 
Tsble 2.4

BREAKDOWN OF MANPOWER REQUIREMENTS BY YEAR AND MAJOR

$$
\text { CATEGORY OE RESEARCH WORKER }
$$

A. Fu11 Progran

\begin{tabular}{|c|c|c|c|c|c|c|c|c|c|c|c|c|c|c|c|c|}
\hline \multirow[b]{2}{*}{ Year } & \multicolumn{16}{|c|}{ FTE } \\
\hline & 1 & 2 & 3 & 4 & 5 & 6 & 7 & 8 & 9 & 10 & 11 & 12 & 13 & 14 & 15 & 16 \\
\hline Laboratory & 38,7 & 36.7 & 37.2 & 27.0 & 12.5 & 10.5 & 13.0 & 10.5 & 7.5 & 1 & 4 & 4 & 5 & 1 & 4 & 0 \\
\hline Modeling & 3.0 & 3.0 & 3.0 & 4.0 & 0.0 & 0 & 2.0 & 0 & 0 & 1 & 3 & 3 & 9 & 7 & 2 & 6 \\
\hline Field & 15.0 & 15.0 & 6.0 & 3.0 & 3.0 & 12.0 & 10.0 & 10.0 & 10.0 & 1 & 0 & 0 & 10 & 14 & 10 & 0 \\
\hline Total & 56.7 & 54.7 & 46.2 & 34.0 & 15.5 & 22.5 & 25.0 & 20.5 & 17.5 & 3 & 7 & 7 & 24 & 22 & 16 & 6 \\
\hline
\end{tabular}

D. Miznimua Program

\begin{tabular}{lrrrrrrrrrrrrrrrrr} 
Laboratory & 37.7 & 36.7 & 23.7 & 13.5 & 9.5 & 7.5 & 9.0 & 6.5 & 6.5 & 0.0 & 0.0 & 0.0 & 5.0 & 5.0 & 4.0 & 0.0 \\
Modeling & 3.0 & 3.0 & 3.0 & 4.0 & 0.0 & 0.0 & 2.0 & 0.0 & 0.0 & 1.0 & 3.0 & 3.0 & 5.0 & 4.0 & 0.0 & 6.0 \\
Field & 17.0 & 14.0 & 6.0 & 3.0 & 2.0 & 12.0 & 10.0 & 10.0 & 10.0 & 1.0 & 0.0 & 0.0 & 10.0 & 10.0 & 10.0 & 0.0 \\
\cline { 2 - 3 } & 57.7 & 53.7 & 32.7 & 20.5 & 12.5 & 19.5 & 21.0 & 10.5 & 16.5 & 2.0 & 5.0 & 3.0 & 20.0 & 19.0 & 14.0 & 6.0
\end{tabular}




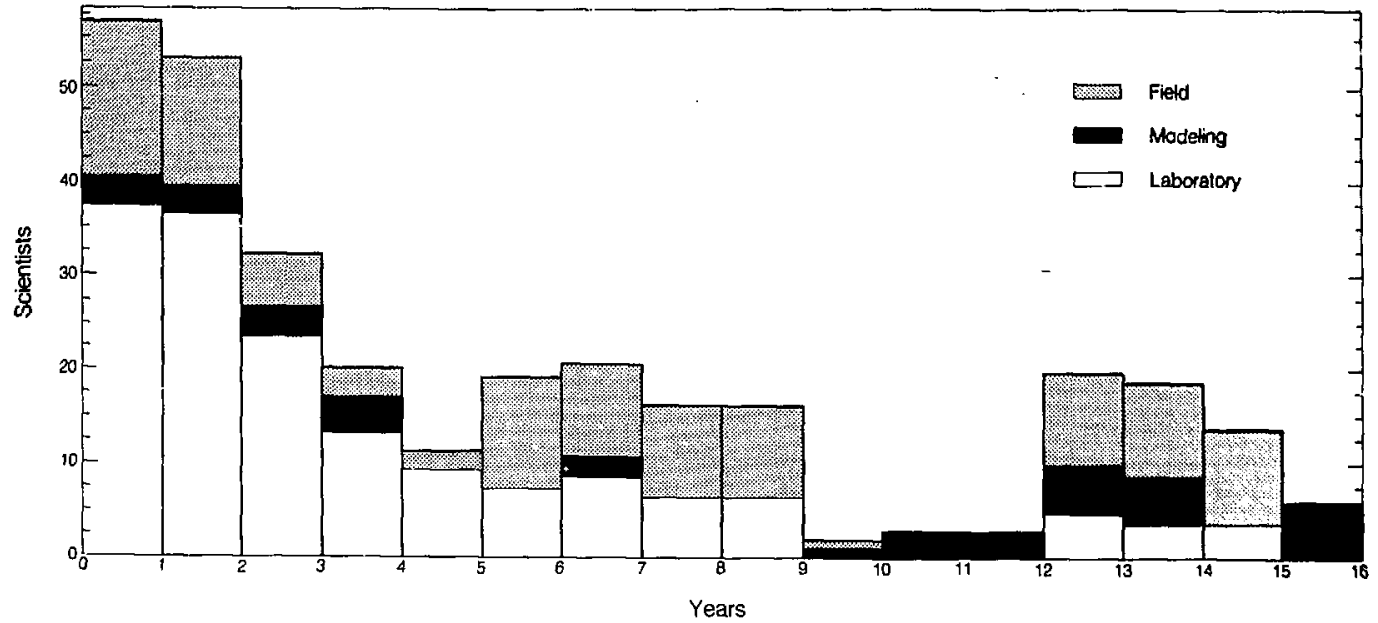

Figure 2.4. Manpower requirements for projects with a minimal level of research needs 
Mapower resources at national laboratories aight be sufficlent. Many project: funded by DOE's WRIT progran have been carried out by staff at national laboratories, and staff in related geoscience and physical chenfatry diaciplines could be assigned to the progran. However, no atteapt had been nade in this report to identify the gtrengths or deficiencies of ataf in relation to current requirenents of the geochenistry research progran.

Specialized laboratory of modeling capabilities outside the national laboratories undoubtedly exist and could be made available, such as those found among leading corporations. University help wight be utilized in some restricted cases, but it is rare that academic institutions posses efther the facilities or supervisory staff to handle radfoactive materials, or the managerfal structure responsive to complex disciplinary programs.

The avaflability of both laboratory and manpower resources for the program may not therefore be a serious problem. However, it should be realized that the actual assignment of staff and coordination. of a program of such a magnitude and complexity will tax the abilities of che best mamagers.

Regarding field programs, the principal problem here lies in the availability of a test facility. Such a facflity must replicate accurately, the conditions expected to be found in a waste repository. This means that ambient temperatures and pressures must be similar. Ambient pressures may be equivalent to those found at depths to 3-4 thousand feet. While it has been emphasized that the direct effect of pressure on chemical processes can be disregarded, (section 2.1.1.1, Apps et al., 1982), several fleld experiments involve backfill materials that must be pressurized to reposftory conditions in order that their physical behavior may be correctly simulated.

Selection and implementation of a fleld testing program appears to be a major difficulty at present, because no faclittles possessing the required conditions are avallable for the principal rock types, other than perhaps for bedded salt at the DOE LOS Medanos facility in New Mexico. This difficulty might be overcome through judicious selection of existing deep mines, provided that political and proprietary considerations can be overcome. It is probably more realistic to schedule in situ field testing when DOE facilities become available.

\subsection{OPTIONS}

The present geochemistry program is unquestionably expensive, of substantial duration, i.e. 16 years, and utilizes a large pool of scientific talent. An approximate estimate of the total cost, assuming one scientist FTE equals $\$ 10 C K(1982)$, is between $\$ 32 M$ and $\$ 38 M$. Furthermore, the assessment of all aspects of the research needs for geochenistry program are not addressed (See Section 3.2 ) so that the cost of a comprehensive program could attain $\$ 50 M$.

Several possibilities exist regarding alternative strategfes for performing geochemistry research in support of waste repository design. 
1. Stretch out the progran over a longer time period

2. Accelerate the program to meet the schedule of the National Waste Policy Act

3. Linit the scope of the program, accepting greater risk

4. Hodify repository specifications and thereby decrease the scope of research required

5. Some appropriate combination of the above.

These alternatives are discussed below.

\subsubsection{Stretching Out the Program}

This approach unquestionably has attractions, especially to those countries where there is not an immediate or pressing need to resolve the problem of disposing of high level commerclal radioactive waste. It has even been advocated by R. Roy (Pennsylvania State University) for the United States program. The advantages are that overall costs of the research could be lower, due to the greater efficiency of using fewer scientists dedicated to the problem, and the benefits gained from information provided by research in associated scientific fields. However, if the whole nuclear fuel cycle is considered, and the costs to the nation of deferring resolution of the high level waste storage problem are also taken into account, with its attendant public concerns regarding the growth of nuclear power, then stretching out of the program could be inappropriate.

\subsubsection{Acceleration of the Program}

The program could be accelerated to meet the requirements of the National Waste Policy Act through addition of more manpower or by increasing the overlap of otherwise sequential projects. The former approach possesses disadvantages such as the need to employ a large number of scientists for a short period of time, with the inefficiencies that such an approach causes. A greater amount of project overlap might be tolerated, but at the expense of increasing management and coordination requirements.

A major stumbling block to decreasing the length of the program is the duration of the field projects. Three of the field projects are four years long. They might be shortened by various means to three or even two years. However, the phenomena to be observed, rely on the establishment of quasi static conditions, which may not to be achleved for some time after initiation of the project. Any attempt to decrease the duration of these projects must await preliminary scoping studies. Only then will it be possible to ascertain whether current estimates are unduly conservative. 
Another approach is to advance the starting date of field experinents and let then sart independently of laboratory, theoretical and nodelling input so essential for proper design of the experinent3. This approach carries with it various risks that can scarcely be justified. Investigation of laboratory research precursor projects shows that their scheduled duration is reasonable when the complexity of the problem is considered (e.g. projects 1.1, 5.2, 5.3).

\subsubsection{Decreasing the Scope of Research}

As conceived, the scope of the present geochemistry research program could not be decreased significantly without jeopardizing the programmatic goal. A few minor projects, e.g. project 7.7 , might be eliminated and some projects relating to engineered barriers, 1.e. backfills, might be integrated. However, with the presently avallable information, neither the duration nor the magnitude of the program could be decreased significantly.

\subsubsection{Modfying Repository Specifications}

A significant reduction in the maximum temperature sustained by a repository would decrease the technical difficulty of predicting the behaviour of a repository for the first few thousand years after closure. In the absence of information on the behavior of systems at temperatures greater than $100^{\circ} \mathrm{C}$, KBS (Sweden) staff decided that the design of their repository would be based on terperatures not exceeding this value. They have designed such a repository and feel confident that thelr approach is adequate. Although further research would lead to more cost effective solutions or increase confidence in the conclusions reached, the major hurcile of establisning feasibility has been overcome.

By adopting a similat approach, and by lowering the temperature specification to around $100^{\circ} \mathrm{C}$, the scope and difficulty of the proposed research could be decreased substantially. Lowering the temperature might be achieved dilution with a non radioactive matrix, by wider spacing of canister materials in the repository, or by combination of all three.

Estimating how much the research requiremencs would be reduced by specifying lower temperature maxima than presently planned is beyond the scope of this report. The size of a repository, and consequently its cost, could increase substantially if a lower maximum repository temperature were mandated by lack of technical confidence. Therefore the cost benefits of the research program to establish the possibility of operating at higher repository temperatures can be estimated approximately. For example, if lowering repository temperatures leads to research cost savings of $\$ 20 M$, but doubling the size of the repository at an additional cost of an additional $\$ 500 \mathrm{M}$, then the logical course of action is clear, and intensifying the research effort would be justified.

Recently, Claiborne (1982) has pointed out that a inulti-barrier system may not significantly decrease the probability fo releasing radioactive waste fron a refository because the probability of failure of the host rock waste package barrier is already so low that additional backup components would not provide a significant additional safety margin. He points out that the barriers are 
easentialig in series and that repository fallure is likely to be due to a comon cause fatlure of all barriers. Obviousiy, the elinination of barriers siplifiez resenrch needs and should decrease the costs of the research progran. Yet it places a heavy reliance on the host rock berrier which is difficult to characterize. Furtherwore, all the findings cited by clafborne (1982) in questioning the efficency of alti-barrier approach are based only upon paper studies. Again, the trade-off between cost and risk need to be estinated, and an acceptable basis worked out.

\section{5 .5 Sumary}

The recomended research plan developed in this chapter, evolved through a sequence of logical steps. The first involved identification of key research needs. This was accomplished by assignment of priorities and classifying the recommendations given in Apps et al., (1982). The recommendations were then formulated as projects and the level of effort of each project estimated.

The projects were then ordered in a logical sequence, most projects taking Input from a precursor, and dellvering output to a successor. Because of the complexity of the network thus created, a computer code, CPMG, was utilized to determine the duration, critical path, and manpower distribution of the program. Program milestones were then identifled and categorized.

Some of the program milestones included decisions affecting both the magnitude and scope of work following those milestones. Therefore, manpower requirements and distribution for the program could not be anticipated precisely. However, a minimum effort program was also computed for comparison, and as a means of bracketing the range of effort that would actually be required. With this information in hand, it was possible to determine whether the resources, i.e. manpower and facllities, would be avallable to do the work required. This was reviewed briefly so that some idea could be given of the approach that would be required if the program were to be implemented.

Finally, consideration was given to options that might be taken in implementing the program. These included efther stretching out or accelerating the program, decreasing the scope of research, or modifying the repository specifications. 


\section{RECOHENDATIONS FOR DEALIKG UITH LIMITATIONS AND DNCERTAIRTIES}

\section{I INTRODUCTION}

This chapter addresses the problens arising from uncertainties in the research plan deecribed in Chapter 2. There are three kinds of uncertainties to be considered:

\section{Technical onissions of the plan.}

2. Uncertainties arising from the implenentation of the plan itself.

3. The difficulties of reconctling the plan with the DOE schedule for constructing a waste repository.

These uncertainties will be addressed in succeeding sections, and with recomendations given for overcoming them.

\subsection{TECHNICAL OMISSIONS OF THE PLAN}

The research plan is comprehensive in its evaluation of the subjects investigated. However, a number of issues were not considered because of the need to reduce the scope of the investigation to manageable proportions and because of both the restricted avallability and the technical skills of scientific staff. Some subjects omltted were not considered to Involve serious issues, although it is always possible that they may become so. The following issues were not considered, but may be important.

1. The need to validate computer simulations of radioactive migration over long time spans through the use of natural analogues.

2. The effect of radiolysis on the oxidation state of groundwaters surrounding the canister.

3. The design of 1 aboratory and field experiments to confirm hypotheses relating to radionuclide tranport,

4. The formulation and utflization of getters to retard selective radionuclides in engineered barriers,

5. The investigation of the effects of different host rocks on radionuclide containment,

6. Consideration of the interaction of borehole plugging material with host rocks,

7. The investigation of the effect of the bulldup of daughter products of transuranic elements,

8. The investigation of the status of data pertaining to radionuclide adsorption on nineral substrates, 
9. Research relating to the design and construction of chenical sensors or monttors for long tern ( $1-5$ years) field tests and possibly for posi closure monitoring (up to 100 years). However, post-closure monitoring 1s not required by 10 CFR Part 60 .

\section{2 .1 Natural Analogues}

Nothing is sore Important to the waste isolation program than providing - weans of independently verifying the wodel concepts embodied in predictions of radionuclide waste aigration. The only plausible way of accomplishing this is to reconcile observations of natural systems with computer siwulations of those systems, using the same models used to predict radionuclide migration. This attractive concept is unfortunately fraught with serious difficulties:

- Cholce of an analogue that adequately replicates the conditions of a repository environment or failing that, being able to select one or more analogues, that in combination will yleld the required verification,

- Having sufficient information on the natural system to $t$ st the model. In particular, the time dimensior: should be adequately defined,

- Being able to combine the skills of three disciplines, vis. hydrology, geochemistry and mathematical modeling to do a creditable analysis of a given analogue.

Research on natural analogues is being conducted under NRC sponsorship, and a promising start has been made. Yet the magnitude of research required for this iuportant phase of the waste isolation program should be augmented through DOE sponsorship. Recommendations are that a meeting of experts be convened, and the matter studied with a view to planning a consolidated program that is compatible with existing research in the waste isolation field.

\subsubsection{Radiolysis}

Uncertainties due to radiolysis center on changes of the oxidation state in the vicinity of the waste canister. A high oxidation state could enhance migration of certain radionuclide species (e.g. actinides in the +6 state and $\mathrm{TC}$ ) and play havoc with predictions of backfill retardation of these species. Nevertheless, most radiolysis is caused by the decay of short lived radionuclides such as $90 \mathrm{Sr}$ and $137 \mathrm{Cs}$, so that the problen could be minimized by surface storage for the next 50 to 100 years, or by development of a canister that provides adequate shielding. Radiolysis is also limited by shielding of the backfill, and by recombination of radiolytic species after a certain concentration of radicals is reached. 
It is recomended that the subject be revlewed and approprlate decistons ade at that tine as to whether further research is justified.

\subsubsection{Design of Laboratory and Field Experiments}

Testing of radionuclide nigration concepts in backfill materials and host rocks is extrewely difficult, if only because of the sall distances travelled by retarding radionuclides during experinentally realistic tines. Most experiments conducted in the field to date involve puming waters containing tracers (usually short lived fission product isotopes) between wells several weters apart. The flow rates, host rock permeabilities, chenfical composition and oxidation state of the fluid usually bear no relation to conditions expected in a repository. Therefore such tests, while better than nothing, are of infited usefulness in confirming theoretical and model concepts.

It is recominted that this subject be reviewed and brainstormed by experts so that specific tests can be recommended and designed. A plan of action that can be incorporated into the geochemlstry plan should emerge from such an evaluation.

\subsubsection{Radionuclide Getters}

Retardation of some radionuclides might be enchanced by the deliberate incorporation of natural or synthetic "getters" in the backfill. A number of these have been proposed particularly for the retardation of 99 Tc and $129 \mathrm{I}$. Recent work on this subject is reviewed and summarized in Smith et al., (1980, RHO-BHI-ST-7, Section 2.8.2.5, pp. 2-272f.)

It- is recommended that specifications be worked out for such getters, and a review and scoping effort undertaken to determine the value of incorporat $(i)$; getters in backfills.

\subsubsection{Eifect of Differing Host Rocks on Radionuclide Containment}

Although this report discusses the effect of host rocks and mineralogy on radionuclide retardation in an attempt to bound the conditions of subsequent experiments, there are a number of subtleties peculiar to differing rock types. For example, basalts are poor in potassium and would therefore tend to favor the formation of smectites over illites. Granites and rhyolitic tuffs are poor in minerals that could exert a strong control over the oxidation potential in the saturating groundwaters.

It is recommended that a geochemist review further the differences between rock types and assess their significance in retarding radionuclides.

\subsubsection{Borehole Plugging Materials}

Although the evaluation and selection of borehole plugging materials really falls into the materials science discipline, borehole plugging naterlals should be selected on the basis of theif physical and chenical stability over long time spans, and their chemical compatibility with surrounding host rocks. These constraints, as with backfill materials, encourage the use of natural materials or synthetic materials whose sinilarity to natural materials is apparent. 
Frojects iaratigating the selection of borehole plugging anterials should be coordinated wth the geochesistry research progran to ensure that a crose fertilization of ldeas takes place.

\subsubsection{Transuranic Elevent Daughters: .}

Al discussions relating to radionuclide aigration in this report ignore the effect of daughter formation resulting from the decay of transuranic elewents. Some of these daughters, for example, radium, are considered very toxic. Furthernore, the complex interactions between radioactive decay and retardation of both parent and daughter can lead to concentration enhancenent of the dughter and the formation of a mgrating front. Although investigations of these phenomena are belng pursued by $T$. PIgford et al, at the University of Calffornia, their significance in the context of the overall waste 1solation program has not been assessed. It is recommended that this subject be evaluated and its significance deternined. At that time appropriate action can be taken with respect to further research.

\subsubsection{Radionuc11de Adsorption on Mineral Substrates}

This subject has been the raison a'etre of the DOE WRIT program. A large amount of research has been performed and suistantial progress has been made toward identifying the parameters controlling adsorption and radionuclide migration. Therefore it is hardly an issue that languishes through lack of recognition or appropriate action. Nevertheless, much research remains to be done and Improved coordination and greater focus on a narrower range of critical questions is now warranted.

It is recomended that this subject be reviewed in coordination with DOE, to identify future direction of this program and determine how it should be integrated into the overall gevchemistry plan.

\subsubsection{Development of Geochemica1 Field Monitors}

Monitoring radionuclide migration during field tests is both conceptually and practically difficult. Both the concentration of the radionuclide, the distance it travels during the course of the test and the amount of fluid in the pores of the rock or backfill, all necessitate specifically designed probes or sensors. This subject should be evaluated in terms of the experimental designs proposed under section 3.2 .3 and recommendations made for further rt search and development.

\subsection{UNCERTAINTIES ARISING FROM IMPLEMENTATION OF THE PLAN}

It should be emphasized at the outset, that the accomplishment of the geochemistry research program plan as laid out in Chapter 2 is not burdened with uncertalnties or a conceptual nature. All research proposed represents an extension of well understood principles and no individual project is expected to cause Insuperable problems. Nevertheless, the proposed research does involve the study of systems far more complex, and under constraints far more demanding than most geoscience research of a similar nature done to date. Therefore, the uncertainties lie in the implenentation, duration, manpower, costs, organfzation and timing of projects in the program. Interfacing with other programs in 
hydrology, geophyates and rock wechantcs is also an important consideration. Duration, anpower and costs have already been reviewed is Chapter 2.0. It reatins here only to discuss the uncertainties ralsed by these subjects and propose appropriate courses of action.

If $1 t$ is deternined iiat the program nust be conplited by a given date, then the uncertainty of duration is renoved fron consideration. Manpower and cost estinate: will require detalled planning, which goes beyond the scope of thi report, before the uncertainties and appropriate responses could be delineated. At this stage, it is recomended that the following actions be taken with respect to each issue.

\subsubsection{Implementation}

It must be deterwined whether all parties involved in the waste isolation program are willing to review geochemistry research needs, accept the present plan or modifiations thereof, and ensure that it is implemented. Imp icit in the plan is the assumption that the program will coordinate with and interface with DOE's current projects. However, as pointeJ out earlier, DOE's cyrrent projects rust be reviewed with principa- +llesibjaior pa.ificipation, co determine in detail the scope of ongoing projects before the progran can be ínalized and implemented.

\subsubsection{Manpower}

Staffing needs must be determined by review of the credentials of potential participants as well as ascertalning tielr avallability for the projects. The impact of staff deficiencles on program accompilshment shovid be identified. Many progra-s are currently underway through DOE spousorship that contain the staff needed for the research programs. Minor changes in direction and better coordination would ensure conilnuity and go towards meeting the programmatic goals. It is recommended that a detailed evaluation be made of stafi aval lability and commitments to existinj projects.

\subsubsection{Custs}

Given the assumption that one scientist requires $\$ 100 \mathrm{~K}$ for support at a major institution, the overall cost of the program will run between $\$ 32 \mathrm{M}-38 \mathrm{M}$. However there is a large measure of uncertainty in these figures, for without detalled bosting by principal investigators, the estimated manpower requirements for the projects are necessarily approximate.

It is recomended that, after Identification of staff, candidate principal inves gators be asked to submit detailed project proposals with budget estimates of assigned tasks.

\subsection{4 organization}

A research program of the complexity of that outlined in Chapter 2 must be properly organized and managed. The present wethod whereby a series of separate contracts are awarded to various institutions has serious disadvantages unless some mechanism is implemented to ensure that the overall program is coordinated on a continuing basis. This wight be accomplished through regular quarterly contractor aeetings in which representatives with decision 
aking authority can report on progress and make adjustments to the progran in response to the accopplishnent or otherwlse of progras allestones. The porenticl incoupatibility of this approach with the award of contracts with clearly defined work statements is recognized.

In general, too little attention has been paid in the past to coordinat ion of large research programs. The magnitude and technical complexity of current programs fully justifies an examination of the potential management structure and determination of the feasibility of setting up an inproved stcucture within the present organization. It is recommended that such an examination be undertaken.

\subsubsection{Tiging of Projects Within the Program}

As discussed in chapter 2 , uncertaintles exist regarding the tiring of certaln projects, particularly field projects, within the research program. These uncertafnties might be resolved by arbitrarily specifying the start up times of fleld projects in the absence of input from laboratory experimental, thecretical and modelling projects. Unfortunately, this approach automatically entails risks that can be translated into uncertainties of cost, wanpower, time or outcome. Given the current state of planning, this uncertainty might be decreased in two ways (a) by following through with detailed evaluations of the preceding uncertainties. This may make the problem clearer, and may suggest that it is less of a problen than expected, or (b) by extending the time taken to complete the program. The latter choice has a direct bearing on the DOE schedule for the waste isolation program, discussed in the following section.

\subsubsection{Interfacing with other Programs}

No consideration has been given in the development of this document, to possible interactions of the geochemistry research program with corresponding programs in hydrology, geophysics and rock mechanics or to the design and selection of waste forms or canisters. It is clear that the geochemistry research program cannot function independently of these other programs, and due consideration must be given to their schedules and aeeds.

It is recommended that a survey of other programs be made to identify conflicts, and to establish the effect such conflicts have on the present frogram.

Scientifically, extension of the repository development program would be justiffed, because this would decrease the risk of premature interpretation of field work, while avoiding the premature initiation of field work. Furthermore, there is no scientific or technical need for immediate implementation of a program to bury SURF or high level waste. There are adequate interim surface storage factlities for spent fuel, and these can, if necessary be expanded to accommodate additional material. However, the institutional issues and past government commitments are such that a scientific rationale is unlikely to have much bearing on present timing. 
It is recomended that both options be explor $\because$ in an effort to seek a re olution to this problem. Investigation of deep underground sites hes Iready been cerried out by LBL ataff under NRC aponsorahip. Thls stue, whlle directed towards different goals, would usefully serve as a basi. for tentative site selection for generic field tests in advance of site specific characterization in dedicated DOE test facilities. 


\section{ACKMORLEDGEMENTS}

This work was supported by the High Level Waste Technical Developient Branch, Division of Wate Managenent, Office of Nuclear Haterial Safety and Safeguards, U.S. Nuclear Regulatory Conisaion, Washington, C.C. 20555, thorugh NRC FIN No. B 3109-0 under Interagency Agreement DOE-50-80-97, through U.S. Department of Energy Contract No. DE-AC03-76SF00098. 
The geologic repastory is a systen of artificial (engineered) and natural barriers, each barrier designed to fulfill a particular function in isolating radioactive waste from the accessible environment.

The geologic repository is divided into a hierarchy of subsystems and components. Rules and regulations governing their performance have been promug gated by the Nuclear Regulatory Commission as 10 CFR Part 60 (Code of Federal Regulations, Title 10, Part 60). These were issued in the Federal Begister, Vol. 46 , No. 37 , p. 13971-13987, on February 25, 1981, as Rules and Regulations and in VoI. 46, No. 120, p. 35288-35296, on July 8, 1981, as Proposed Rules.

The relationship of the system components to each other and to the NRC rules and regulations must be understood in order to clarify the geochemlstry issuez and organize a geochemistry research plan. Figure A.1 is an organization chart showing the interrelationship of the component parts of the geologic repository system. The items enclosed in the boxes with the heavy borders are those 1 dentified and defined or conceptualized in 10 CFR Part 60. The remainder are incorporated for compleceness. All are listed in Table A.1 with the definftions or conceptual explanations from 10 CFR part 60 .

Table A.2 summarlzes the systems approach to a geologic repository and relates the materials and barrier parameters to critical questions concerning their function. The tasks smerging frow the questions, decision points, and pertinent sections from 10 CFR Part 60 are incorporated in the table and correlated with the relevant barriers. This table is the basis for organizing the tasks in which current geochemistry research is evaluated. It also summarizes the underlying systems approach to defining geochemistry research needs for an underground waste repository. Additional sections from 10 CFR Part 60 , wnich deal with the repository is general, or with more than one barrier, are appended after the notes in Table A.2. 


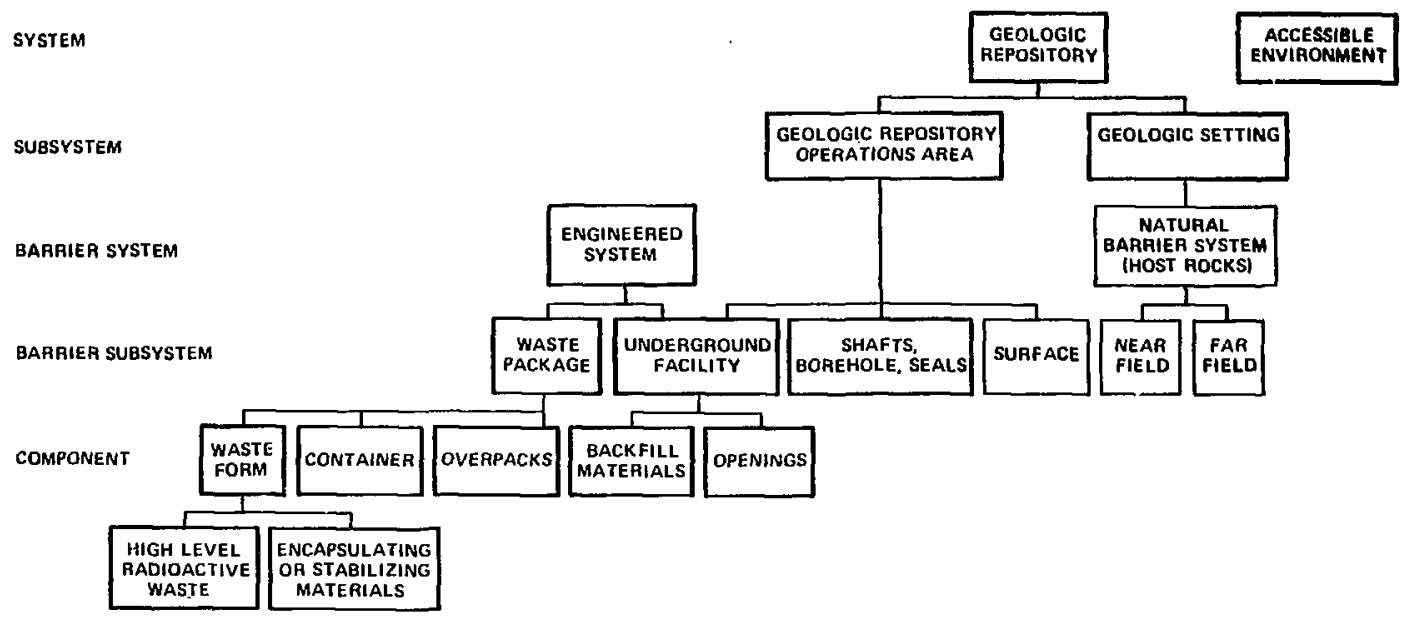

Figure A.1. Organization chart to show the hierarchy of subsystems and components of a geologic repository.

[XBL, 828-2381] 
Table A.1. Definitions and Concepts.

\section{Accessible Environent}

The accessible environment seans those portions of the enviroment directly in contact with or readily available for use by huan beings.

[\$60.102, Concepts, (f)]

\section{Backf 111}

See Underground Facility.

Contalner

A waste package includes: The container, which is the first major sealed enclosure that holds the waste form.

$$
\text { [\$60.102, Concepts, (e)] }
$$

Encapsulating Material

See Waste Form.

Engineered System

The engineered system includes the waste packages as well as the underground facility.

$$
\text { [\$60.102, Concepts, (e)] }
$$

Far Field

The far field is that part of the geologic setting which is unaffected by mechanical or thermal effects caused by emplacement of the geologic repository.

[Undefined by NRC]

Geologic Repository

Geologic reposicory means a system which is intended to be used for, or may be used for, the disposal of radioactive wastes in excavated geologic formations. A geologic repository includes (1) the geologic repository operations area and (2) all surface and subsurface areas where natural events or activities of man may change the extent to which radioactive wastes are effectively isolated from the biosphere.

$$
\text { [\$60.2, Definitions, (h)] }
$$


Table A.1 (cont.)

\section{Geologic Repository Operations Area}

A geologic repository operations area consists of those surface and subsurface areas that ere part of a geologic repository where radioactive wasce handilng activities are conducted.

$$
\text { [560.102, Concepts, (b), (2)] }
$$

\section{Geologic Setting}

There is a large area, designated the geologic setting or site which includes the spatially distributed geologic, hydrologic, and geochemical systems that provides 1solation of the radioactive waste from the accessible environment. The geologic repository operations area plus the geologic setting make up the geologic repository. With1n the geologic setting, particular attention must be given to the characteristics nf the host rock as weIl as any rock units surrounding the host rock.

$$
\text { [560.102, Concepts, (c)] }
$$

High-Leve1 Radioactive Waste

"H1gh-Level radioactive waste" or "HLW" means (1) irradiated reactor fuel, (2) liquid wastes resulting from the operation of the first cycle solvent extraction system, or equivalent, and the concentrated wastes from subsequent extraction cycles, or equivalent, in a facility for reprocessing irradiated reactor fuel, and (3) sollds into which such liquid wastes have been converted.

$$
[\$ 60.2 \text {, Definftions, (j)] }
$$

Natural Barrier System

The natural barrier system consists of all those barriers to radionuclide migration that were part of the geologic setting prior to construction of the geologic repository.

[Undefined by NRCl

Near Field

The near field is that part of the geologic setting which is affected by mechanical or thermal effects caused by emplacement of the geologic repository.

[Undefined by NRC]

Openings

See Underground Fac1lity. 
Table A.1 (copt.)

Overpack

A waste package includes: Overpacks which consist of any buffer atterial, receptacle, wrapper, box or other structure that is both within and an integral part of a waste package. It encloses and protects the waste form so as to neet the performance objectives.

$$
[\$ 60.102, \text { Concepts, (e)] }
$$

Shafts

See Geologic Repository Operations Area.

Surface

See Geologic Repository Operations Area.

Underground Factlity

The underground structure fncluding openings and backfill materfals, but excluding shafts, boreholes, and their seals, is designated the underground factility.

$$
\text { [\$60.102, Concepts, (b), (2)] }
$$

Waste Form

A waste package includes: The waste form which consists of the radioactive waste materials and any associated encapsulating or stabilizing materials.

$$
\text { [\$60.102, Concepts, (e)] }
$$

Waste Package

A waste package Includes:

(1) The waste form

(2) The container

(3) Overpacks

[\$60.102, Concepts, (e)] 
Tebie A.2. Cheatsery of ceologic unte Isolecion; Probleo definition.

\begin{tabular}{|c|c|c|}
\hline syaken & Eepleyte Anponteory & \\
\hline Sibryatce & Coslogle mpositery Operatione Area & \\
\hline sarriar syaren & Enqunered syscen & \\
\hline arreter subnyste: & Whate Peckepe & \\
\hline Component & Waste Fors & Concainer and packing waterial \\
\hline Nuterisels & 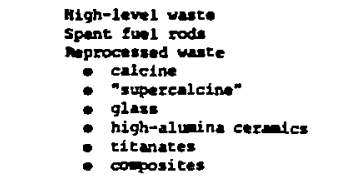 & $\begin{array}{l}\text { Cast 1ron } \\
\text { Carbon steel } \\
\text { seninless steel } \\
\text { Copper } \\
\text { Alundu } \\
\text { Titaniu alloys } \\
\text { Componites } \\
\text { Inner and auter packing } \\
\text { material }\end{array}$ \\
\hline $\begin{array}{l}\text { Paracters Affecting } \\
\text { Redionuelide Isolation }\end{array}$ & 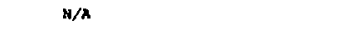 & $\mathbf{W} / \mathbf{A}$ \\
\hline Questions & $\mathrm{N} / \mathrm{A}$ & $\mathrm{N} / \mathrm{A}$ \\
\hline Tasks & $H / A$ & $N / A$ \\
\hline Destsion Points & $\mathbf{s} / \mathrm{A}$ & $\mathrm{s} / \mathrm{A}$ \\
\hline $\begin{array}{l}\text { Pertinente sections fron } \\
10 \text { CFr pare to (asc) }\end{array}$ & Sec tote 1 at end of table. & \\
\hline
\end{tabular}


Table A.I (cont.)

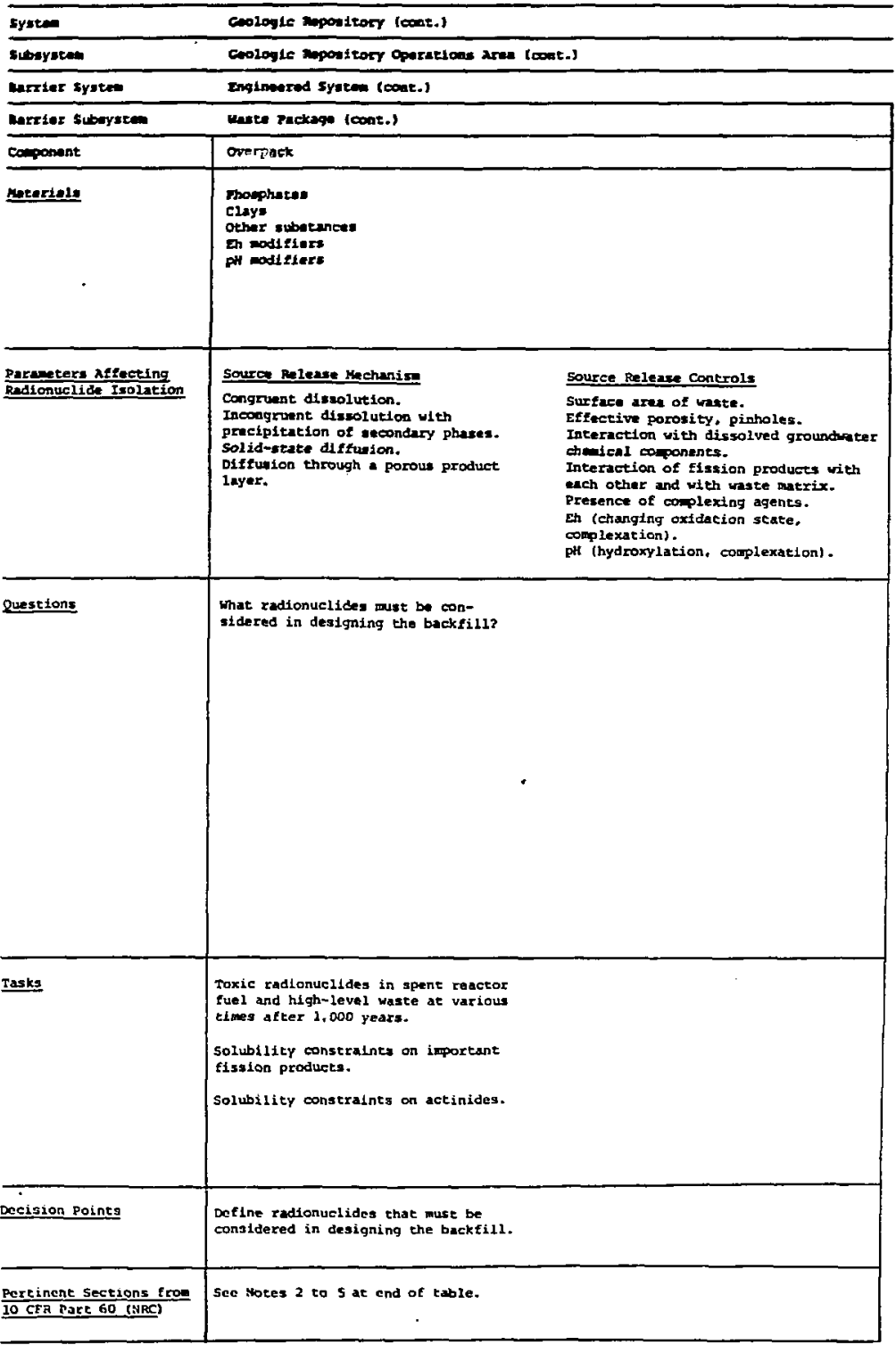


Iande A.1 (cont.)

\begin{tabular}{|c|c|c|}
\hline Syetron & \multicolumn{2}{|l|}{ Coolente repositor lcont.) } \\
\hline Sturotem & \multicolumn{2}{|l|}{ Eodople erpository opratlons ared lone.) } \\
\hline Marrier sytten & \multicolumn{2}{|l|}{ Depiavered sroten (cont.) } \\
\hline Derrier subyoten & \multicolumn{2}{|l|}{ Underqroind Facil1ty } \\
\hline Canponat & \multicolumn{2}{|l|}{ macket11 } \\
\hline Perefine & \multicolumn{2}{|l|}{ 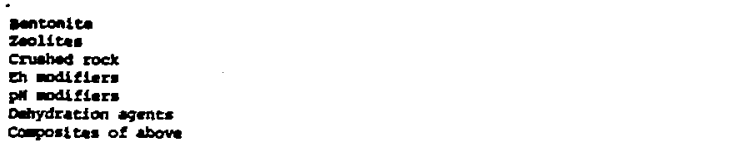 } \\
\hline $\begin{array}{l}\text { Partaters Aftecting } \\
\text { Padionuglide Ifolation }\end{array}$ & 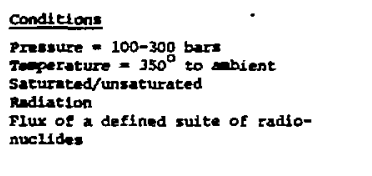 & $\begin{array}{l}\text { Physical/Chenical Properties } \\
\text { Porosity, } \$ \\
\text { Permeability, y } \\
\text { Surface area, A } \\
\text { Tortwosity. T } \\
\text { Chenical conposition } \\
\text { Msorgtion capacity } \\
\text { Ion-exchange capacity }\end{array}$ \\
\hline Ouestions & 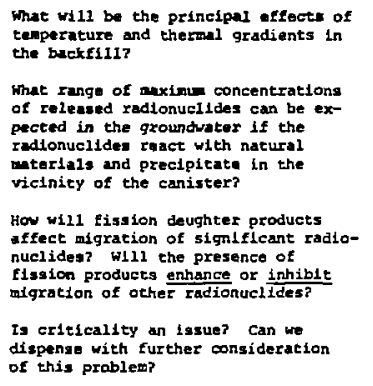 & 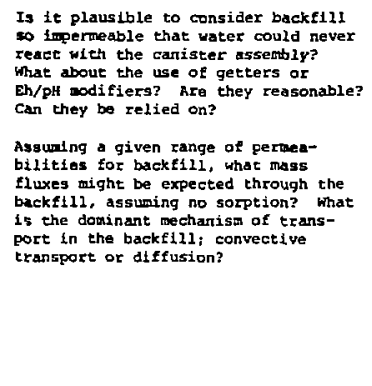 \\
\hline rasks & 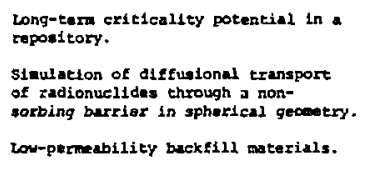 & . \\
\hline Decision points & . & \\
\hline $\begin{array}{l}\text { Pertincne sections fron } \\
\text { 10 CFA pare 00 (URC) }\end{array}$ & See Notes 6 and 7 at and of cable. & \\
\hline
\end{tabular}


Inte $x, 1$ (a)nt,

\begin{tabular}{|c|c|c|c|}
\hline syares & 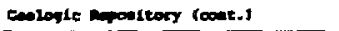 & & \\
\hline surerecen & Enlogit mponitory Operation area & $(\cos )$. & \\
\hline Earrier syotes & tondened syiten (cont.) & & \\
\hline Earrier subrytu & undergroned Foellity (cont.) & & \\
\hline Compenent & 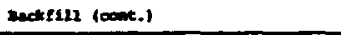 & & - \\
\hline materials & 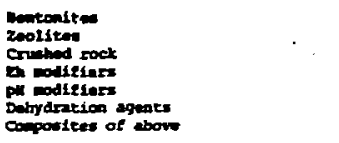 & & \\
\hline
\end{tabular}

Purmeters aftecting Pedionicilde Isolistion

\section{Ireneported ronen}

Ionic

(Including coplexes)

Holecular

(including copplexes)

colloldal

particulate

\section{Transport, Hechenisies}

convetion

Advection

Diffurion
Petardation rectianize:

Adroxption

Interlayer tonfe exchange

zeollte erchange

Ion exchange

Precipitation
Questions
Begring in wind that colloidal por tfeles diffuse at much slower motes than lonic and polecular species, ent ue dispore of the colloidal particles probles if only diffualve transport occura?

Given a reasonuble knowledge of ratardation confficlents and pormenbilities, how thick wat a backf11] be to rotard critical radionuclldes

to innoevols lavels? are there tinicknerees ruaronable?
That effect would different backfill enteriale have on the degree of retardation? whe 1f. in addietion to adiorption, Ion exchange ware to take place? How would this affect retardation? what radionuclides cannot be adequately contained by an engincered barrier?

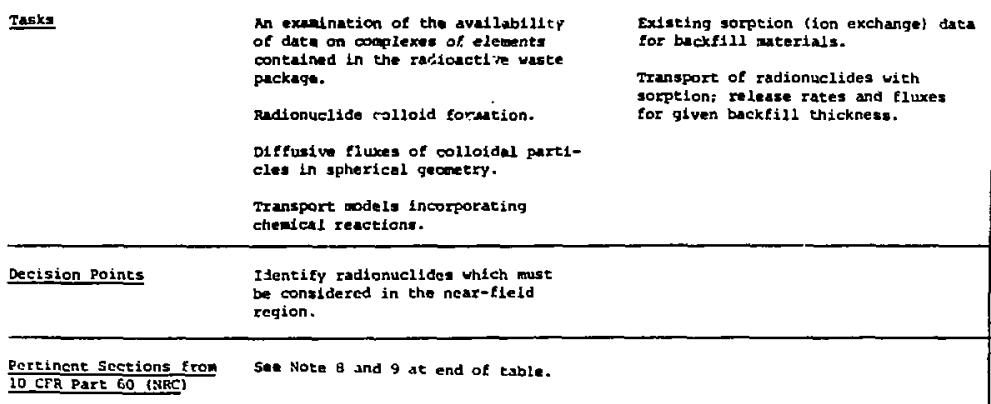


$x=10 \mathrm{~A} .1$ (ant.)

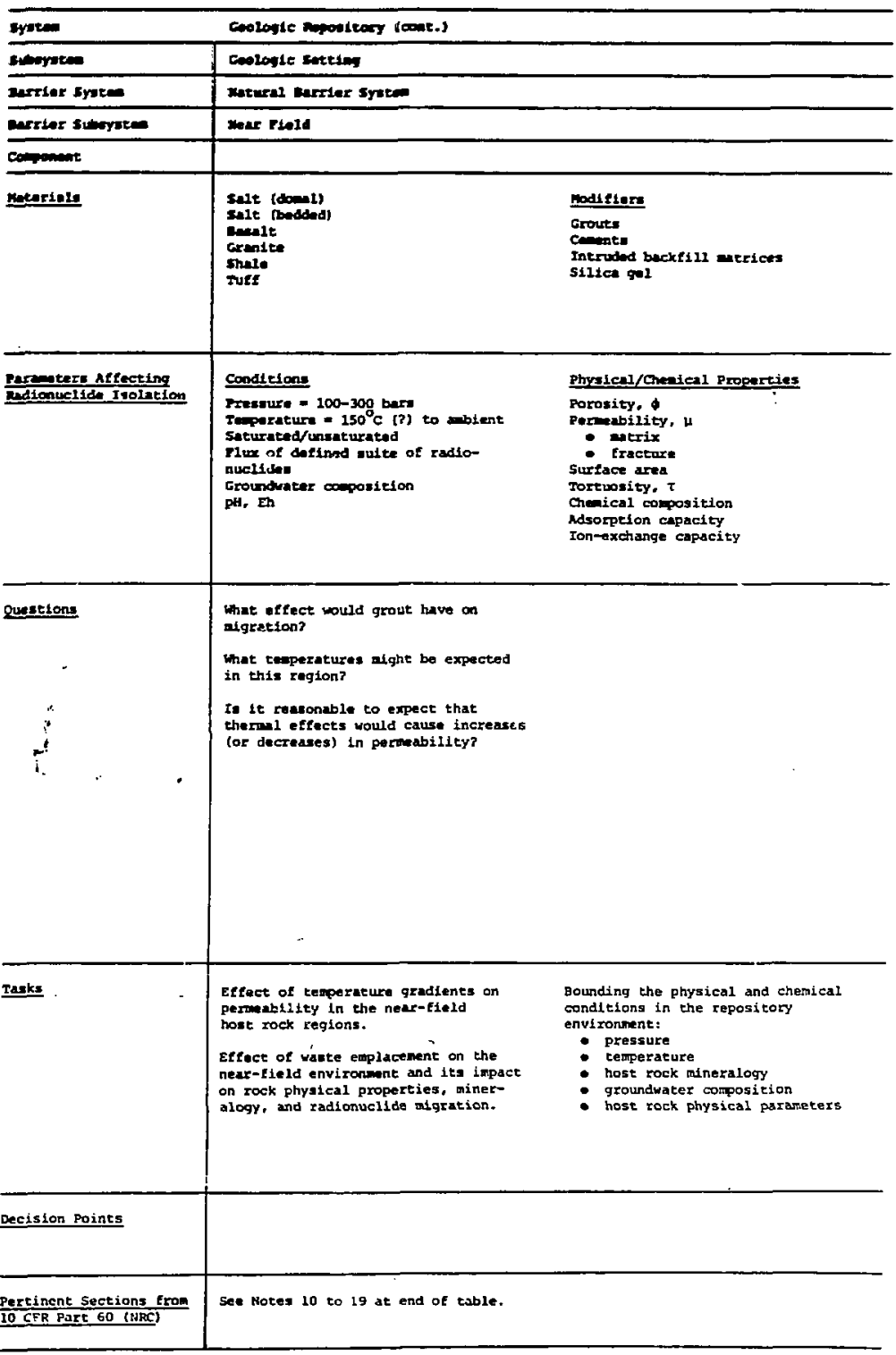


Inble a.1 (cont.)

\begin{tabular}{|c|c|c|}
\hline syoten & Cnolagle aponitory (cont.) & \\
\hline subryter & eniogte settidon (cont.) & \\
\hline serrier systen & wataral vastier systen (cose.) & \\
\hline Earrias subuyaten & were Fleld roont.) & \\
\hline \multicolumn{3}{|l|}{ component } \\
\hline Eter1ale & 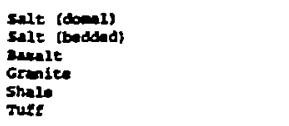 & 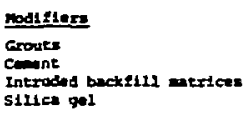 \\
\hline
\end{tabular}

\section{Peramers affecting} Radlonuclice Isalo

\section{Transported Forn}

Ionic

(1neluding onplexas)

vileculas

(including complexes)

Colloidal

particulace

\section{Transport yechanise}

Convection

Adrection

Diffusion
Betardintion Mectanis

adworpeton

Interlayer ion exchange

zeolite exchange

Ion exchange

Precipitation

pore diffusion

\section{Mestions}

If it likely that for-exchange processe:

and precipltation could significantly

rutard radionuelidan in the nevr-tield

rogian? By approximetely how mach?

What range of thlekress would be re-

quired if diffusion in the aqueous

phese were the sole transport mechanisw? 
Table A.1 (cont.)

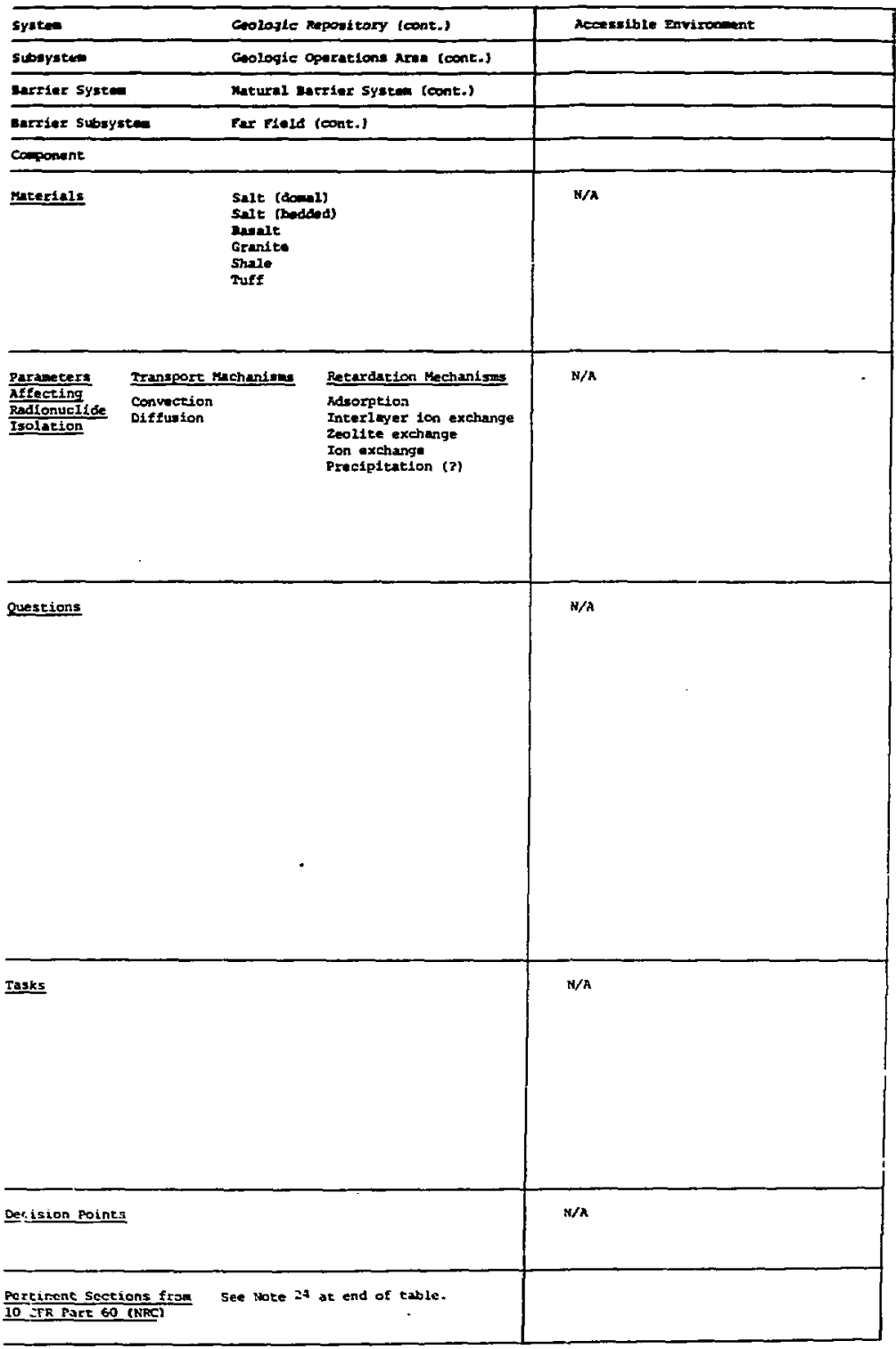


1. (2) Performance of the engineered system. (1) Containuent of wates. The engineered cysten shall be desigaed so that even if full or partial saturation of the underground factlity were to occur, and assuming enticipated processes and events, the waste packages will contain all radionucildes for at least the first 1,000 years after peranent closure. This requirement does not apply to TRU waste unless TRU waste is emplaced close enough to HLW that the TRU release rate can be significantly affected by the heat generated by the HLW.

$$
\begin{aligned}
& \text { [560.111, Performance objectives, (b), } \\
& (2),(1)]
\end{aligned}
$$

2. (2) Protection against natural phenomena and environmental conditions. (i) The structures,-systems, and components 1mportant to safety shall be designed to be compatible with anticipated site characteristics and to accommodate the effects of environmental conditions, so as to prevent interference with normal operation, maintenance, and testing during the entire period of construction and operations.

$$
\begin{aligned}
& {[\$ 60,130 \text {, General design requirements }} \\
& \text { for the geologic reposttory operations } \\
& \text { area, (b), (2), (1)] }
\end{aligned}
$$

3. (a) General criterla for the underground facility.

(1) The underground facility shall be designed so as to perform its safety functions assuming Interactions among the geologic settiog, the underground facility, and the waste package.

[\$60.132, Additional design requirements for the underground facility, (a),(1)]

4. (a) General requirements of design.

(1) Effect of the site on the waste package. The waste package shall be designed so that the in situ chemical, physical, and nuclear properties of the waste package and its interactions with the emplacement environment do not compromise the function of the waste packages. The design shall include but not be limited to consideration of the following factors: solubility, oxidation/reduction reactions, corrosion, hydriding, gas generation, thermal effects, mechanical strength, mechantcal stress, radiolysis, radiation damage, radionuclide retardation, leaching, fire and explosion hazards, thermal loads, and synergistic interactions. 
4 (cont.)

(2) Effect of the waste package on the underground facllity and the natural berriers of the geologic setting. The wate package shall be designed so that the In situ chenical, physical, and nuclear properties of the waste package and 1 ts interactions with the enplacentent environwent do not conpronise the performance of the underground factlity or the geologic setting. The design shall laclude but not be linited to consideretion of the following factors: solubility, oxidation/reduction reactions, corrosion, hydriding, gas generation, thermal effects, aechanical strength, mechanical stress, radiolysis, radiation damage, radionucl ide retardation, leaching, fire and explosion hazards, thermal loads, and synergistic interactions.

[\$60.135, Requirements for the waste package and its components, (a), (1), (2)]

5. Monitoring and testing waste packages.

(a) A program shall be established at the repository for monitoring the condition of the waste packages. Packages chosen for the program shall be representative of those to be emplaced in the repository:

(b) Consistent with safe operation of the repository, the environment of the waste packages selected for the waste package monitoring program shall be representative of the emplaced wastes.

(c) The waste package monttoring program shall includè 1aboratory experiments which focus on the internal condition of the waste packages. To the extent practical, the environment experienced by: the emplaced waste packages within the repository during the waste package monitoring program shall be duplicated in the laboratory experiments.

(d) The waste package monitoring program shall continue as long as practical up to the time of permanent closure.

[\$60.143, Monitoring and testing waste packages !

6. (8) Criticality control. All systems for processing, transporting, handling, storage, retrieval, emplacement, and isolation of radioactive waste shall be designed to ensure that a nuclear criticality accident is not possible unless at least two unlikely, Independent, and concurrent or sequential changes have occurred in the conditions essential to nuclear criticality safety urder normal and accident conditions. The calculated effective multiplication factor ( $K_{e f f}$ ) must be sufficiently below unity to show at least a $5 \%$ margin, after allowance for the blas in the method of calculation and the uncertalaty in the experiments used to validate the method of calculation.

[\$60.130, General design requirements for the repository operations area, (b),$(8)]$ 
7. (1) Engineering barriers.

(1) Barriers shall be located were shafts could allow access for groundwater to enter or leave the undergrcund facilfty.

(2) Barriers shall create a waste packape enviroment which favorably controls chentcal reactions affecting the performance of the wate package.

(3) Backfill placed in the underground facility shall be designed as a barrier.

(i) Backf1ll placed in the underground facility shall perform its functions assuming anticipated changes in the geologic setting.

(11) Backfill placed in the underground facility shall serve the following functions:

(A) It shall provide a barrier to groundwater movement into and from the underground facility.

(B) It shall reduce creep deformation of the host rock that may adversely affect (1) waste package performance or (2) the local hydrological system.

(C) It shall reduce and control groundwater movement within the underground facility.

(D) It shall retard radionuclide wigration.

(iii) Backfill placed in the underground facility shall be selected to allow for adequate placement and compaction in underground openings.

$[\$ 60.132$, Additional design requirements for the underground facility, (1), (1), (2), (3)]

8. Design Testing

(a) Diring the early or developmental stages of construction, a program for in situ testing of such features as borehole and shaft seals. backfill, and the thermal interaction effects of the waste packages, backfill, rock and groundwater shall be conducted.

(b) The testing shall be Initlated as early as is practicable.

(c) A backfill test section shall be constructed to test the effectlveness of backfill placement and compaction procedures against design requirements before permanent backfill placement is begun. 
(d) Test sections shall be established to test the effectiveuess of borehole and shaft seals before full-scale operation proceeds to seal boreholes and shafts.

\author{
[560.142, Design testing]
}

9. (11) Control of releases.

(A) For HLW, the engineered system shall be designed so that, after the first 1,000 years following permanent closure, the annual release rate of any radionuclide from the engineered system into the geologic setting, assuning anticipated processes and events, is at nost one part in 100,000 for the maxinum amount of that radionuclide calculated to be present in the underground facility (assuming no release from the underground facility) at any time after 1,000 years following permanent closure. The requirement does not apply to less than 0.17 of the total annual curie release as prescribed by this paragraph.

(B) For TRU waste, the engineered system shall be designed so that following permanent closure the annual release rate of any radionuclide from the underground facility into the geologic setting, assuming anticipated processes and events, is at most one part in 100,000 of the maximum amount calculated to be presented in the underground facllity (assuming no release from the underground facility) at any time following permanent closure. This requirement does not apply to radionuclides whose contribution is less than $0.1 \%$ of the annual curie release as prescribed by this paragraph.

[\$60.111, Performance objectives, (b), (2), (11)]

10. (b) The geologic setting shall have exhibited hydrogeologic, geochemical, and geomorphic stability since the start of the Quaternary Period.

$[\$ 60.112$, Required characteristics of the geologic setting, (b)]

11. Favorable conditions

(h) Mineral assemblages that, when subjected to anticipated thermal loading, will remain unaltered or alter to mineral assemblages having increased capacity to inhibit radionuclide migration.

(i) Conditions that permit the emplacenent of waste at a minimum depth of 300 meters from the ground surface. (The ground surface shall be deemed to be the elevation of the lowest point on the surface above the disturbed zone.)

(j) Any local condition of the disturbed zone that contributes to Isolation. 
12. (k) Design for theran loads.

(1) The underground facility shall be designed so that the predicted theras and thermonechanical response of the rock will not degrade Ignificantly the perforance of the repository or the ability of the natural or engineered barriers to retard radionuclide algration.

(2) The design of waste loading and waste spacings shall take 1nto considerstion:

(1) Effects of the design of the underground factlity on the thermal and thermomechanical response of the host rock and the groundwater systen.

(11) Features of the host rock and geologic setting that affect the thermomechanical response of the underground faclilty and barriers, including but not limited to, behavior and deformational characterIstics of the host rock, the presence of insulating layers, aquifers, faults, ortentation of bedding planes, and the presence of discontinuities in the host rock.

(1i1) The extent to whlch fracturing of the host rock is influenced by cycles of temperature Increase and decrease.

[ $\$ 60.132$, Additional des1gn requirements for underground facility, (i) Englneered barriers, $(k),(1),(2)]$

13. Potentially adverse conditions

Evidence of dissolution of soluble rocks.

[\$60.123, Potentially adverse conditlons, (b) Adverse conditions in the disturbed zone, (5) l

14. Potentially adverse conditions, continued.

(13) Conditions in the host rock that are not reducing conditions.

(14) Groundwater conditions in the host rock, including but not limited to high lonic. strength or ranges of $\mathrm{Eh}-\mathrm{pH}$ that could affect the solubility and chemical reactivity of the englneered system.

(15) Processes that would reduce sorption, result in degradation of the rock strength, or adversely affect the performance of the engineered system.

(16) Rock or groundwater conditions that would requfre complex engineering measures in the design and construction of the underground facility or in the sealing of boreholes and shafts,

[\$60.123, Potentially adverse condItions, (b) Adverse conditions in the disturbed zone, (13-16)] 
15. (e) Design of subsurface openings.

(1) Subsurface openings shall be designed to maintain stability throughout the construction and operation periods. If etructural support is required for stability, it shill be designed to be compatible with long-term deformation, hydrologic, geochenical, and therwonechanical characteristics of the rock and to allow subsequent placenent of backfill.

[\$60.132, Additional design requirements for underground facllity, (e), (1)]

16. (e) Design of subsurface openings.

(3) Subsurface openings shail be designed to reduce the potential for deleterlous rock movement or fracturing of overlying or surrounding rock over the long term. The size, shape, orlentation, and spacing of openings and the design of engineered support systems shall take the following conditions into consideration--

(1) Natural stress conditions.

(11) Deformation characteristics of the host rock under normal conditions and therwal loading.

(111) The kinds of weaknesses or structural discontinuities found at various locations in the geologic repository.

(1v) Equipment requirements.

(v) The ability to construct the underground facllity as designed so that stability of the rock is enhanced.

[ $\$ 60.132$, Additional deslgn requirements for underground facllity, (e), (3)]

17. (f) Rock excavation. The design of the underground facility shall incorporate excavation methods that will limit damage to and fracturing of rock.

[\$60.132, Additional design requirements for the underground factlity, (f)]

18. Design of shafts and seal 8 for shafts and boreholes.

(b) Shaft and borehole seals.

(2) At the time of permanent closure, sealed shafts and boreholes will inhibit transport of radionuclides to at least the same degree as the undisturbed units of rock through which the shafts or boreholes pass. In the case of soluble rocks the borehole and shaft seals shall also be designed to prevent groundwater circulation that would result in dissolution. 
(3) Contact between ahaft and borehole seals and the adjacent rock does not become a preferential pathway for water.

(4) Shaft and borehole seals can accomodate potential variations of stress, tenperature and moisture.

(5) The terial used to construct the seals are appropriate in view of the geochemistry of the rock and groundwater system anticipated deformations of the rock and other in situ conditions.

[ $\$ 60.133$, Design of shafts and seals for shaf to and boreholes]

19. (d) rosk excavation. The methods used for excavation shall be selected to reduce to the extent practicable the potential to create a preferential pathway for groundwater or radioactive waste migration or increase migration through existing pathways.

[560.134, Construction specifications for surface and subsurface facilities, (d)]

20. Favorable conditions

(c) The nature and rates of hydrogeological processes that have occurred since the start of the Quaternary Perlod are such that, when projected, they would not affect or would favorably affect the ability of the geologic repository to isolate the waste.

$$
\text { [ } \$ 60.122 \text {, Favorable conditions, (c)] }
$$

21. Favorable conditions, continued

(d) The nature and rates of geochemical processes that have occurred since the start of the Quaternary Perlod are such that, when projected, they would not affect or would favorably affect the ability of the geologic repository to isolate the waste.

$$
\text { [\$60.122, Favorable conditions, (d)] }
$$

22. Favorable conditions, continued

(g) Geochemical condittons that (1) promote precipitation or sorption of radionuclides; (2) Inhibit the formation of particulates, cuiloids, and inorganic and organic complexes that increase the mobility of radionuclides; and (3) Inhibit the transport of radionuclides by particulates, colloids, and complexes.

$$
\text { [\$60.122, Favorable conditions, (g)] }
$$


23. Faworable conditions, continued

(f) A host rock that provides the following grounduater character1stics-(1) low groundrater content; (2) Inhibition of groundwater circulation In the host rock; (3) Inhibition of groundrater flow between hydrogeologic units or along shafta, drifts, and boreholes; and (4) grounduter travel tines, under prewaste enplecenent conditions, between the uriderground facility and the accessible environment that substantially exceed 1,000 years.

\section{[560.122 Favorable conditions, (f)]}

24. (b) Performance of the geologic respository after peranant closure. (1) overall system performance. The geologic setting shall be selected and the subsurface facility designed so as to assure that releases of radioactive materlals from the geologic repository following permanent closure conform to such generally applicable environmental radiation protection standards as may have been established by the Environmental Protection Agency.

[\$60.111, Performance objectives, (b), (1)]

Additional Sections from 10 CFR Part 60 Pertinent to Repository Geochemistry

Licence Application

(c) The Safety Analysis Report shall include:

(1) A description and analysis the site at which proposed geologic repository operations area 18 to be located with appropriate attention to those features that might affect facility design and performance. The assessment shall contain an analysis of the geology, geophysics, hydrology, geochemistry, and meteorology of the site and the major design structures, systems, and components, both surface and sub-surface that bear significanty on the sultability of the geologic repository for disposal of radioactive waste.

(2) A description and discussion of the design, both surface and subsurface of the geologic repository operations area including:

(1i1) Iriformation relative to materials of construction (including geologic media, general arrangement, and approximate dimensions) (3) A description and analysis of the design and performance requirements for structures, systems, and components of the geologic repository which are important to safety. The analysis and evaluation shall consider (111) the effectiveness of engineered and natural barriers, including barriers that may not be themselves a part of the geologic repository operations area against the release of radioactive material to the environment. 
(a) The DOE shil subit an epplication to anend the license prior to daconissioning. The application thall consist of an update of the 1 tcense application and enviromental report subitced under 560.21 and 60.22 Including:

(3) Geologic, geophystcal, geochenical, hydrologic and other site data that are obtained during the operational perlod pertinent to the longtern leolation of enplaced radiosctive wastes.

(4) The resul ts of tests, experiments and any other analysea relating to beckfill of excavated areas, waft sealing, waste interaction with enplacenent nedia and any other test experiments or analyses pertinent to the long-tern isolation of enplaced waste within the geologic repository.

[560.51, License amendment to decomaission]

\section{Subpart F- Performance Confirmation}

(a) The performance conf1rmation program shall ascertain whether:

(1) Actual subsurface conditions encountered and changes in those conditions during construction and waste emplacement operations are within the 1imits assumed in the licensing review: and (2) Natural and engineered systems and components required for repusitory operation or which are designed or assumed to operate as barriers after permanent closure are functioning as intended and anticipated.

(b) The program shall have been started during site characterization and it will continue until permanent closure.

(c) The program will Include in situ monftoring laboratory and field testing and in situ experiments as may be appropriate to accomplish the objective as stated above.

(d) the confirmation program shall be implemented so that:

(1) It does not adversely affect the natural and englneered elements of the geologic repository.

(2) It provides baseline information and analysis of that information on those paramecers and natural processes pertaining to the geologic setting that may be changed by site characterization construction and operational activities.

(3) It monitors and analyzes changes from the baseline condition of parameters that could affect the performance of a geologic repository.

(4) It provides an established plan for feedback and analysis of data and implementation of appropriate action. 
APREDLX B. LIST OF RESEALCA FOJECTS CORAET In 1981

REF.ID - 1 CATECORY - MASS TRNSPORT

DOCX.TYPE - GENERAL

REF.TYPE- PROJECT - Trace-Elenent Tranaport In Geol1ge Hedia

PRINCIPAL INVESTIGatoRs: Se1tz, M. G.; Couture, R. A.

LOCATION: Argonne National Lab., II:. 80439

FUNDING AGENCY: DOE.

COMMENTS: Study fundanental mechantsms that underlie transport by fluid flow of trace elements in rocks.

INFORMATION SOURCES FOR THIS PROJECT: DOE/ER-0071 (Aug. 1980)

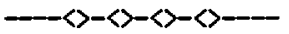

REF.ID - 2

ROCK.TYPE - GENERAL

REF.TYPE - PROJECT - Migration of Heavy Element Chemtcal Species in Geologic Strata

PRINCIPAL INVESTIGATORS: Fried, S. M.; Friedman, A. M.; Sullivan, J. C. LOCATION: Argonne National Lab. Ill. 60439

FUNDING AGENCY: DOE.

COMMENS: Study the fundamental parameters affecting the rate of transport of radionuclides from a potentlal nuclear waste site located in deep geologic media. Specific concerns are condicions that affect oxidation states and hence the migration rates of various actinide lons that may be leached by ground water from a source emplaced in a deep geologic repository.

INFORMATION SOURCES FOR THIS PROJECT: DOE/ER-0071 (AUg. 1980)

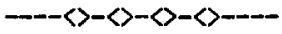


REF.ID - 3 CATECOKI - MSS TRANSPORT

ROCK.TYPE - BASALT, OTHER

REF.TYPE- PROJECT - Investigation of Hechanisas that Control Concentration of Radionuclides in Geologic Solution

PRINCIPAL INUESTIGATORS: Ra1, D.; Strickett, D. G.

LOCATION: Pacif1c Northwest Lab., RIchland, Wash. 99352

EUDING AGENCY: DOE.

COMENTS: Deternine the wechanisms and the effects of various factors (such as pH, Eh, complexing and competing ligands, tracer concentration, oxidation state of the element, solid phases, etc.) in controlling the concentration of elements in solutions in equilibrium with different geomedia. Contar lnated Hanford solls were used to determine the factors or mechan.sms controlling the concentration of $\mathrm{Pu}$ and Am in solutions contacting these soils.

INFORMATION SOURCES FOR THIS PR'JJCT: DOE/ER-0071 (Aug. 1980)

REF.ID(S) OF ASSOCIATED DOCUMENTS: PNL

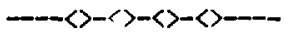

REF.ID - 4 CATEGORY - NUCLIDES/ROCK INTERACTIONS

ROCK.TYPE - GRANITE, OTHER

REF.TYPE - PROJECT - Chemlcal Migration by Contact Metamorphism in Granite-Carbonate Rocks

PRINCIPAL INVESTIGATORS: Laul, J. C.

LOCATION: Pacific Northwest La)., Rfchland, Wash. 99352

FUNDING AGENCY: DOE.

COMENTS: Study the migration of major, minor, and, in particular, trace elements during contact metamorphism between granite and carbonate rocks. Specific emphasis will be on the rare earth elements and barium ( $\mathrm{Ba}$ ), strontium ( $\mathrm{Sr}$ ), rubidium (Rb), cesium ( $\mathrm{Cs}$ ), zirconium (Zr), hafnium (Hf), nickel (Ni), thorium (Th) and uranfum (v). The geologic site under study is the Notch Peak intrusion near Delta in western Utah.

INFORMATION SOURCES FOR THIS PROJECT: DOE/ER-007I (Aug. 1980)

REF.ID(S) OF ASSOCIATED DOCUMEN :S: PNL

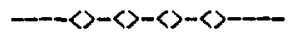


IEF.ID - 5 CATECORY - NATURAL Argatodues

ROCX. TYPE - GEHERI

TEF.TYPE - PROJECT - Idencificacion of Environinente Providing

Effective waleiple Natural Bartiers to Radionuclide Transport

PRINCIPAL INVESTIGATORS: Hale, W. E., USGS, Albuquerque

LOCATION: Contact: G. D. DeBuchananne, 703-860-6976

DURATION: Continuing

FUNDIISG AGENCY: DOE/ESTP

COHINTS: Identify or contribute to the Identification of environments with hydrodynamic; geochemical, and geologic characteristics that provide independent multiple natural 'arriers to the migration of radionuclides and chat may warrant intensive study.

INFORIATION SOURCES FOR THIS PROJECT: DOE/TIC 11033 (Draft) AprII 1980

REF.ID(S) OF ASSOCLATED DOCUMENTS: USGS

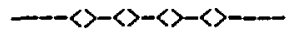

REF.ID - 6 CATEGORY - POTENTIAL SITES, U.S.

ROCK.TYPE - GENERAL

REF.TYPE - PROJECT - National Screentng of Geologic Environments

PRINCIPAL INVESTIGATORS:

LOCATION: Contac' R. R. N1cks, 614-424-4406

DURATION: Two years

FUNDING AGENCY: DOE/ESTP.

COMMENT: Identify portions of conterminous U.S. with potential for waste isolation, based on a comprehensive literature search of geologic and environmental data.

INFORMATION SOURCES FOR THIS PROJECT: DOE/TIC 11033 (DRAFT) AprAI 1980

REF.ID(S) OF ASSOCIATED DOCUNENTS; DOE/RL-C/ONWI

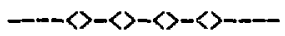


REF.ID - 7 CATEGORY - SITE CHARACTERIZATION, SOUTHEASTERN U.S. ROCK.TYPE - ARGILLACEOUS, CRYSTALLINE

REF.TYPE - PROJECT - Geologic Evaluation of Southeastern U.S. PRINCIPAL INVESTIGATORS: Marine, I. W., Sandia Research Laboratory LOCATION: Contact: R. R. N1cks, 614-424-4406

DURATION: two years

FUNDING AGENCY: DOE/ESTP.

COMENTS: Evaluate potential of geologic f rmations in southeastern U.S., especially crystalline rocks of Piedmint Province and argillaceous rocks of the Southeastern Coastal Plain, for the disposal of radioactive wastes.

INFORMATION SOURCES FOR THIS PROJECT: DOE/TIC-11033 (draft) April 1980

REF,ID(S) OF ASSOCLATED DOCUMENTS: DOE/RL-C/ONWT, SAIND

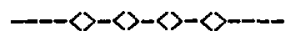

REF.ID - 8 CATEGORY - SITE CHARACTERIZATION, PALO DURO AND DALHERT BASIN, TEXAS

ROCK.TYPE - BEDDED SALT

REF.TYPE - PROJECT - Evaluation of West Texas Bedded Salt

PRINCIPAL INVESTIGATORS: Handford, C. R., TBEG

LOCATION: Contact: W. E. Newcomb, 614-424-7685

DURATION: Continuing

FUNDING AGENCY: DOE/ESTP.

COMRENTS: Evaluate regional geologic and hydrologic environments of Palo Duro and Dalhart Basins of West Texas where extensive bedded salt occurs; assist in selecting study areas for detailed characterization; and to inventory the natural resources of the basins.

INFORMATION SOURCES FOR THIS PROJECT: DOE/TIC 11033 (draft) April 1980

REF.ID(S) OF ASSOCIATED DOCUMENTS: DOE/RL-C/ONWI, RHO

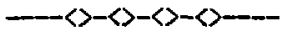


REF.ID - 9 CATEGORY - SITE CHARACTERIZATION, PARADOX BASIN ROCK.TYPE - BEDDED SALT

REF.TYPE - PROJECT - Geologic Evaluation of Paradox Barin PRINCIPAL INVESTIGATORS: McMilian, D. (UGMS); Hite, R. (USGS); Conwe11, F. (Woodward-Clyde)

LOCATION: Contact: N. A. Frazier, 614-424-7688

DURATION: Continuing

FUNDING AGENCY: DOE/ESTP.

COMMENTS: To conduct, in sequence, regional, area, and site Investigations for purposes of 1dentifying, characterizing, and licensing a repository in bedded salt.

INFORMATION SOURCES FOR THIS PROJECT: DOE/TIC 11033 (draft) April 1980

REF.ID(S) OF ASSOCIATED DOCUMENTS: DOE/RL-C/ONWI, USGS

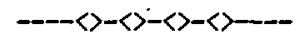

REF.ID - 10 CATEGORY - POTENTIAL SITES, U.S. - CRYSTALLINE

ROCK.TYPE - CRYSTALLINE

REF.TYPE - PROJECT - Survey of Crystalline Rock

PRINCIPAL INVESTIGATORS: WIDaI, R. M. (Particlpant: Dames and Moore)

LOCATION: Contact: R. R. Ni.cks, 614-424-4406

DURATION: One year

FUNDING AGENCY: DOE/ESTP.

COMENTS: Perforn reconnalsence survey of occurrences of crystalline rocks in the U.S. with potential for radloactlye waste 1solation.

INFORMATION SORUCES FOR THIS PROJECT: DOE/TIC 1L033 (draft) April I 980

REF.ID(S) OF ASSOCIATED DOCUMENTS: DOE/RL-C/ONWI

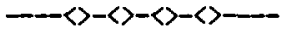




\section{REF.ID - 11 CAIEGORY - HOST ROCKS, ROCK SALT}

\section{ROCK.TYPE - ROCK SALT}

REF.TYPE - PROJECT - Salt Perweability

PRINCIPAL INVESTIGATORS: Wayland, J.R.

DURATION: Three years

FUNDING AGENCY: USGS/ESTP.

COMMENTS: Assess permeability of southeastern New Mexico rock salt for gas and liquid migration studies.

INFORMATION SOURCES FOR THIS PROJECT: DOE/TIE 11033 (draft) APril 1980

REF.ID(S) OF ASSOCIATED DOCUMENTS: DOE/ALO/WIPP, SAND

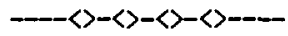

REF.ID - 12 CATEGORY - HOST ROCKS, GRANITE

ROCK.TYPE - PROJECT - Properties of Grante and other Crystalline Rocks

PRINCIPAL INVESTIGATORS: Peterman, 2. E.; Byerlee, J. R. (USGS),

LOCATION: Contact: E. R. Roseboom, 703-860-6631

DURATION: 5 years

FUNDING AGENCY: DOE/ESTP/USGS.

COMENTS: Assess properties of granite and other crystalline rocks in a generic manner as a gulde to future exploration for repository sites.

INFORMATION SOURCES FOR THIS PROJECT: DOE/TIC 11033 (draft) APril 1980

REF.ID(S) OF ASSOCIATED DOCUMENTS: USGS

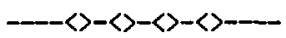


REF.ID - 13 CATEGORY - HOST ROCKS, ARGIHACEOUS

ROCK.TYPE - ARGILLACEOUS

REF.TYPE - PROJECT - Laboratory Evaluation of Arglllaceous Rocks for Nuclear Waste Contaiment

PRINCIPAL INVESTIGATORS: Brunton, G. (Participant: ORAL)

LOCATION: Contact: R. R. NIcks, 614-424-4406

DURATION: Continuing

FUNDING AGENCY: DOE/ESTP.

COMMNTS: Perform fundamental investigation of physico-chemical properties of argillaceous rocks, and to 1dentify and document their sultability as waste repository hosts.

INFORMATION SOURCES FOR THIS PROJECT: DOE/TIC 11033 (draft) AprII 1980

REF.ID(S) OF ASSOCIATED DOCUMENTS: DOE/RL-C/ONWI, ORNL

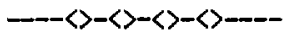

REF.ID - 14 CATEGORY - HOST ROCKS, SHALE

ROCK . TYPE - SHALE

REF.TYPE. - PROJECT - Shale Structure Studies

PRINCIPAL INVESTIGATORS: Weaver, C. (Partic1patnt: Georgia Inst, of Tech.)

LOCATION: Contact: J. O. Duguid, 614-424-4773

DURATION: Continuing

FUNDING AGENCY: DOE/ESTP.

COMMNTS: Determine effect of elevated temperature on chemical/physical structure of shales.

INFORMATION SOURCES FOR THIS PROJECT: DOE/TIC 11033 (draft) April 1980

REF.ID(S) OF ASSOCIATED DOCUMIENTS: DOE/RL-C/ONHI

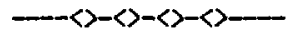


HEF.ID - 15 CATECORY - ROCK/SOLUTION INTERACTIONS

BOCK.TYPE - SALT

REF.TYE - PROJECT - Effect of Water on salt Repository

PRINCIRAL I:TVESTIGATORS: Baes, C., ORNL

LOCATION: Contact: J. P. KIrcher, 614-424-4871

DURaTIOL: Continuing

FUNDING AGENCY: DOE/ESTP.

Commis: To gain information sufficient to predict credibly the consequences of any plausible forn of water breeching a salt repository that wight compromise the integrity of that repository. study effects on water on salt, in terms of dissolution rates and reprecipitation, and as functions of temperature, flow rate and salt particle size distribution.

INFORMATION SOURCES FOR THIS PROJECT: DOE/TIC 11033 (draft) April 1980

REF.ID(S) OF ASSOCIATED DOCUMENTS: DOE/RL-C/ONHI, ORNL<smiles>CC=CC=CC=CC=CC</smiles>

REF.ID - 16 CATEGORY - RADIONUCLIDE TRANSPORT

ROCK.TYPE - NA

REF.TYPE - PROJECT - Geochemistry of Transuranium Elements

PRINCIPAL INVESTIGATORS: Cleveland, J. M. (participant: USGS)

LOCATION: Contact: G. D. DeBuchananne, 703-860-6976

DURATION: Continuing

FUNDING AGENCY: DOE/ESTP.

COMENTS: Characterize chemical and physical forms of iransuranium elements in contaminated natural water and to determine interactions of these elements with other solutes. To interpret this information so that it can be used to develop criteria for identifying repository sites where the ground-water properties would minimize the formation of soluble, mobile transuranic species.

INFORHATION SCURCES FOR THIS PROJECT: DOE/TIC 1103 (draft) APril 1980

REF.ID(S) OF ASSOCIATED DOCURENTS: USGS

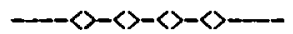


REF.ID - 17 CATEGORY - RADIONUCLIDE/SOLUTIOA INTERACTIOAS

ROCK. TYPE - GENERAL

REF.TYPE - PROJECT - Theraodynandc Properties of Actinides

PRINCIPAL INVESTIGATORS: Edelstein, N., LBL

LOCATION: Contact: J. F. K1rcher, 614-424-4871

DURATION: Three years

FUNDING AGENCY: DOE/ESTR.

COMMENT: Provide thermodynamic data on the spectes, oxidation states, and concentrations of radionuclides in solution under geologic repository conditions.

IIFORMATION SOURCES FOR THIS PROJECT: DOE/TIC 11033 (DRAFT) APril 1980

REF, ID(S) OF ASSOCIATED DOCURENTS: DOE/RL-C/ONWI, LBL

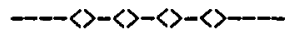

REF.ID - 18 CATEGORY - WASTE/ROC: INTERACTIONS, LEACHING

ROCK. TYPE - GENERAL

REF.TYPE - PROJECT - WRIT (Waste Rock Interaction Technology), Leaching

PRINCIPAL INVESTIGATORS: Bradley, D., PNL

LOCATION: Contact: J. F. Kircher, 614-424-4871

DURATION: CONtInuing

FUNDING AGENCY: DOE/ESTP.

COMMENTS: To determine waste form release rates and help provide source terms for consequence analysis. To characterize candidate waste forms, to measure leach rates with solutions and under conditions simulating expected repository conditions, and to determine effects of physical and chemical factors on release mechanisus.

INFORMATION SOURCES FOR THIS PROJECT: DOE/TIC 11033 (draft) April 1980

REF.ID(S) UF ASSOCIATED DOCUNEENTS: DOE/RL-C/ONWI, PNL

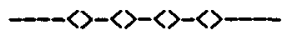


RER.ID - 19 CATECOAY - MASTE/GEOHEDLA INTERACTIOHS

IOCX.TYPE - BEDDED SALT

REF.TYPE - PROJECT - Transuranic waste Characterization: Studies Under conditione of Geologic Isolation

PRIMCIPAL INVESTIGATORS: MOlecke, M. A. (SLA), LASL, SRI, UNM

LOCATION: Contact: M. A. Molecke, 505-264-0781

DURATION: Continuing

FUNDING AGENCY: DOE/ESTP.

COMNENTS: Obtain data and predictive analytical models on interaction and degradation behavior of existing and developuent TRU wastes in a bedded salt repository.

INFORMATION SOURCES FOR THIS PROJECT: DOE/TIC-11033 (draft) April 1980

REF.ID(S) OF ASSOCIATED DOCIMENTS: DOE/ALO/WIPP,<smiles></smiles>

REF.ID - 20 CATEGORY - ENGINEERED BARRIERS

ROCK.TYPE - GENERAL

REF.TYPE - PROJECT - Engineered Barriers

PRINCIPAL INVESTIGATORS: Simpson, D. R. (Lehigh)

LOCATION: Contact: D. P. Moak, 614-424-7125

DURATION: Continuing

FUNDING AGENCY: DOE/ESTP.

COMMENTS: Consider engineered barrier concepts as they affect near-field isolation.

INFORMATION SOURCES FOR THIS PROJECT: LUE/TIC 11033 (draft) APr11 1980

REF.ID(S) OF ASSOCIATED DOCUMENTS: DOE/RL-C/ONWI

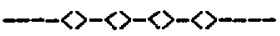


REF.ID - 21 CATEGORT - ENGINEERED RARRIERS

ROCK.TYPE - BASALT

REF.TYPE - PROJECT - Waste/Barrier/Rock Interactions in Basalt

PRINCIPAL INVESTIGATORS: RHO, PSL, PNL .

LOCaTION: Contact: M. J. Smith, 509-942-7782

DURATION: Continuing

FUNDING AGENCY: DOE/ESTP.

COMENTS: To determine hydrothermal interactions which will occur following a worst circumstance breach of engineered barrier system. Hydrothermal experiments w11 be condurted at elevated temperatures and pressures to simulate effects of depth and radiogenic heating.

INFORMATION SOURCES FOR THIS PROJECT: DOE/TIC-110133 (draft) April 1980

REF.ID(S) OF ASSOCIATED DOCUMENTS: DOE/RL/BWIP, RHO, PNL<smiles>C=C=CC=CC=CC</smiles>

REF.ID - 22 CATEGORY - ENGINEERED BARRIERS - CANISTERS, BACKFILL, OVERPACK MATERIALS

ROCK.TYPE - PROJECT - Engineered Barrier Optimlzation

PRINCIPAL INVESTIGATORS: RHO, PNL

LOCATION: Contact: M. J. Smith, 509-942-7782

DURATION: Continuing

FUNDING AGENCY: DOE/ESTP.

COMENTS: Initial literature search to determine candidate materials for canister, overpack, and backfill. Do hydrothermal tests to assess the materials' stability in hydrothermal environment. Evaluate potentials for radiation damage of selected candidate materials.

INFORHATION SOURCES FOR THIS PROJECT: DOE/TIC-11033 (draft) APIII 1980

REF.ID(S) OE ISSOCIATED DOCUMENTS: DOE/RL/BWIP, RHO, PNL

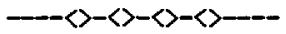


REF.ID - 23 CATECORY - POTERTIA SITES, U.S. - ARgILLACEOUS

NOCK. TIPE - ARGILLACEOUS

IEF.TYPE - PROJECT - Survey of Argilleceour Rocks

FRINCIPAL INVESTIGATORS: Johneon, K. S.; Gonzales, S.

LOCATION: Contact: R. R. Nicks, 614-424-4406

DURATIOW: 2 years

FUNDING AGENCY: DOE/ESTP. .

COHMENT: Perform reconnaissance survey of occurrences of argillaceous rocks in the U.S. with potential for radioactive waste Isolation.

INFORMATION SOURCES FOR THIS PROJECT: DOE/TIC-111033 (draft) April 1980

REF.ID(S) OF ASSOCIATED DOCUMENTS: DOE/RL-C/ONWI

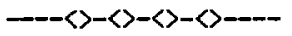

REF.ID - 24 CATEGORY - HOST ROCKS, GRANITE, SALT, SHALE

ROCK.TYPE - SALT, GRANITE, SHALE

REF.TYPE - PROJECT - Expected Repository Environments

PRINCIPAL INVESTIGATORS: Claiborne, H. C. (ORNL); Rickertsen, L. D. (SAI); Callahan; G. D. (RE, SPEC)

LOCATION: Contact: G. Raines, 614-424-783

DURATION: Continuing

FUNDING AGENCY: DOE/ESTP.

COMENTS: Identify refurence conditions in salt, shale, and granite repositories to serve as guide for; scientists conducting material performance tests, engineers preparing design of repositories, technically conservative conditions to be used as bases for DOE application of a license, and scientists and engineers developing waste forms.

INFORMATION SOURCES FOR THIS PROJECT: DOE/TIC-11033 (draft) April 1980

REF.ID(S) OF ASSOCIATED DOCUMENTS: DOE/RL-C/ONWI and ORNL

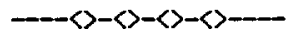


REF.ID - 25 CATEGORY - SITE CHARACTERIZATION, COLURABA PLATEAJ

ROCK.TYPE - BASALT

REF.TYPE - PROJECT - Regional Geology of the Columbia Plateau

PRINCIPAL INVESTIGATORS: EHO, State of Oregon, Ideho, Mashington, USGS, others

LOCATION: Contact: T. A. Curran, 509-942-6409

DURATION: To Sept. 1981

FUNDING AGENCY: DOE/RL/BWIP.

COMMENTS: Provide support for site selection and evaluation; input for site characterization report, environmental report, and draft environmencal impact otatement. The knowledge obtained from this effort will be used to characterize surrounding regional geology and natural geologic events that occurred or may occur in the future.

INFORMATION SOURCES FOR THIS PROJECT: DOE/TIC-I1033 (draft) APIII 1980

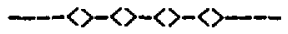

REF.ID - 26 CATEGORY - SITE CHARACTERIZATIONS, ITSS

Nevada Test Site (NTS) and Vicinity

PRINCIPAL INVESTIGATORS: LEAP, D. I. (USGS)

LOCATION: Contact: Scott Sinnock, 505-264-2365

DURATION: Two to six years

FUNDING AGENCY: DOE/ESTP.

COMMENTS: Assess and digitally model in two dimensions hydrologic flow system of the NTS and surrounding areas.

INFORMATION SOURCES FOR THIS PROJECT: DOE/TIC-11033 (draft) April 1980

REF.ID(S) OF ASSOCIATED DOCUNENTS: DOE/NVO, UGS 
EET.ID - 27 CATECORY - SITE EVALUATION, GULF COAST SAIT DOIES

ROCK.TIPE - DOHE SALT

REF.TIPE - PROJECT - Evaluation of Gulf Coast Salt Dones (Texas, Lowisiana, Missiesippi)

PrincIPal InvestigatoRs: Pauls, D. E. (LeTCO); Kreitler, C. W. (TBEG); Martinez, J. D. (LSU); Spiers, C. A. (USGS); Ryals, G. (USCS); Pauleon, 0 . (USH)

LOCATION: Contact: P. F. Patchick, 614-424-7693

DUgaTIoN: Continuing

FUNDING AGENCY: DOE/ESTP.

COMIENS. Evaluate regional geologic and hydrologic environment of Gulf Interior Region where numerous salt domes occur; se areas for detalled characterization; to inventory natural resources of the basin.

INFORMATION SOURCES FOR THIS PROJECT: DOE/TIC-11033 (draft) April 1980

REF.ID(S) OF ASSOCIATED DOCUNENTS: DOE/RL-C/OWI, USGS<smiles>C=C=CC=CC=CC</smiles>

REF.ID - 28 CATEGORY - NUMERICAL ANALYSIS, RADIONUCLIDE TRANSPORT, PASCO BASIN

ROCK.TYPE - BASALT

REE.TYPE - PROJECY - Integraced System Description of Basalt Hydrologic Regime, Preliminary Model Adaptations, and Modeling of Potential Credible Scenarios

PRINCIPAL INVESTIGATORS: Wash., Dept. of Ecol.; Georesults; BCS RIchland RHO; USGS: State of Inc.; Research Management Association

LOCATION: Contact: R. L. BIggerstaff, 509-942-7206

DURATION : $\quad 1979-1992$

FUNDING AGENCY: DOE/ESTP.

COMENTS: Provide numerical analysis techniques for evaluation of radionuclide movement within the hydrologic system at the candidate site and within the Pasco Basin.

INFORMATION SOURCES FOR THIS PROJECT: DOE/TIC-1103 (draft) April 1980

REF.ID(S) OF ASSOCIATED DOCUMENTS: DOE/RL/BWIP, RHO, USGS 
KEF.ID - 29 CATECORY - SITE EVALUATION, YUCCA WOURTAIN AREA, NIS ROCK.TYPE - TUFF

REF.TYPE - PROJECT - Characterization of Yucca Kountain Area, Nevada Test Site

PRINCIPAL INVESTIGATORS: Dixon, G. L. (USGS); Crowe, B. M. (LASL); wNO Support Contractors

LOCATION: Contact: Scott Sinnock, 505-264-2365

DURATION: One to $\mathrm{six}$ years

FUNDING AGENCY: DOE/ESTP.

COMENTS: Assess geologic geophysical and hydrologic characteristics of Yucca Mountain portion of southwestern NTS in sufficient detail to permit judgement about sultability of a contained site(s).

INFORMATION SOURCES FOR THIS PROJECT: DOE/TIC-1103 (draft) April 1980

REF.ID(S) OF ASSOCIATED DOCUMENTS: DOE/NVO, USGS, LA

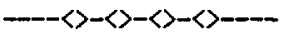

REF.ID - 30 CATEGORY - SITE EVALUATION, NTS

ROCK.TYPE - TUFF, GRANITE

REF,TYPE - PROJECT - Evaluation of Candidate Areas, Southern Nevada

PRINCIPAL INVESTIGATORS: Smedes, H. W. (USGS)

LOCATION: Contact: Scott Sinnock, 505-264-2365

DURATION: Two to four years

FUNDING AGENCY: DOE/ESTP.

COMMENT: To identify the most promising locallties for waste isolation in southern Nevada, with special emphasis on the southwest quadrant of the Nevada Test Site (NTS).

INFORMATION SOURCES FOR THIS PROJECT: DOE/TIC-11033 (draft) Apr1I 1980

REF.ID(S) OF ASSOCIATED DOCUMENTS: DOE/NVO, USGS

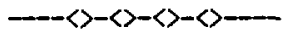


REF.ID - 31 CATECORY - HOST RDCKS, ANHTDRITE

BOCK.TYPE - ANTYDRITE

REF.TYPE - PROJECT - Anhydrite Studies

PRINCIPAL INVESTIGaTORS: Dean, H. E. (USGS)

LOCATION: Contact: E. R. Roseboon, 703-860-6631

DURATION: Three years

FUNDING AGENCY: DOE/ESTP.

COMENTS: Evaluate sultability of anhydrite as medium for radioactive waste repository; to inventory and summarize geologic, hydrologic, physical, and chemical characteristics of anhydrite occurrences in the conterminous U.S, and to identify areas and topics for more intensive investigation.

INFORMATION SOURCES FOR THIS PROJECT: DOF/TIC-11033 (draft) APIII 1980

REF.ID(S) OF ASSOCIATED DOCUMENTS: USGS<smiles>CC=CC=CC=CC</smiles>

REF.ID - 32 CATEGORY - SITE GHARACTERIZATION, GROUNDHATER SYSTEMS, WIPP

ROCK. TYPE - PROJECT - Characrerization of Local Ground-Water Syatem at VIPP

PRINCIPAL INVESTIGATORS: Gorzales, D. D. (SLA); Mercer, J. W. (USGS)

LOCATION: Conţact: D. D. Gonzales, 505-264-8849

DURATION: Continuing

FUNDING AGENCY: DOE/ESTP.

COMMENTS: Obtain descripticn of hydrologic systems for radionuclide migration modeling at WIPP. These will include potentiometric levels, perweabilities, transmissivities, flow rates, and water samples from wells penetrating water-bearing units in WIPP area. Do hydrologic testing of commerclal exploratory holes penetrating evaporites near the boundaries of WIPP area.

INFORMATION SOURCES FOR THIS PROJECT: DOE/TIC-11033 (draft) APxil 1980

REF.ID(S) OF ASSOCIATED DOCUMENTS: DOE/ALO/WIPP, SAND, USGS

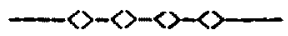


REF.ID - 33 CATEGORY - HOST ROCKS, SALT

ROCK.TYPE - SALT

REF.TYPE - PROJECT - Evaporite Origins and Phase Relations in the WIPP Area

PRINCIPAL INVESTIGATORS: Lambert, S. J. (SLA)

LOCATION: Contact: S. J. Lambert, 50S-264-7876

DURATION: Four years

FUNDING AGENCY: DOE/ESTP.

COMMNTS: To determine, empirically and theoretically, conditions of stability and phase relations of evaporite minerals for evaluating effects of physicochemical perturbations of heating experiments and hole plugging experiments.

INFORMATION SOURCES FOR THIS PROJECT: DOE/TIC-11033 (draft) April 1990

REF.ID(S) OF ASSOCIATED DOCUNENTS: DOE/ALO/WIPP, SAND<smiles>C=CC=CC=CC=CC</smiles>

REF.ID - 34 CATEGORY - WASTE/GEOMEDIA INTERACTIONS

ROCK.TYPE - BASAL'T, OTHER

REF.TYPE - PROJECT - Characterization of Waste Form and Geologic Environment for BHIP

PRINCIPAL INVESTIGATORS: RHO, LBL, Hanford Engineering Dev. Lab., PNL LOCATION: Contact: M. J. Stith, 509-942-i782

DURATION: TO Sept. 1984

FUNDING AGENCY: DOE/ESTP.

COMENTS: To obtain phystcal, chemical, and structural data from analyses of candidate waste forms, natural ground waters, and potential geologic barriers. This information is necessary to interpret experimental results and assess the degree to which hydrologic transport of toxic waste materials is inhibited by geologic media such as basalt and associated secondary minerals and interbed materials.

INFORNATION SOURCES FOR THIS PROJECT: DOE/TIC-11033 (draft) April 1980

REF.ID(S) OF ASSOCLATEL DOCUMENTS: DOE/RL/BWIP, RHO, LBL, PNL

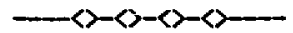


REF.ID - 35 CATEGORY - WASTE/LOCK INTERACTIONS, BRINE MIGRATION

ROCK.TYPE - SALT

REF. TYPE - PROJECT - Near-Field Waste-Rock Interactions

PRINCIPAL INVESTIGATORS: ROY, D. M. (PSU)

LOCATION: Contact: D. P. Moak, 614-424-7125

DURATION: Continuing

FUNDING AGENCY: DOE/EST'P.

COMENTS: Investigate consolidation (compaction) behavior of crushed salt and to study brine migration in polycrystalline salt in a thermal gradient. To determine nature of any chemical or mineralogical shanges in, or interaction between, various waste forms and host rock (primarily shale).

INFORMATION SOURCES FOR THIS PROJECT: DOE/TIC-11033 (draft) April 1980

REF.ID(S) OF ASSOCIATED DOCUMENTS: DOE/RL-C/ONWI

REF.ID - 36 CATECORY - ENGINEERED BARRIERS - WASTE

PACKAGE/GEOMEDIA INTERACTIONS

ROCK.TYPE - SALT

REF.TYPE - PROJECT - Salt-Brine-Was-e-Canister Interactions

PRINCIPAL INVESTIGATORS: Potter, R.; USGS

LOCATION: Contact: J. 0. Duguid, 614-424-4773

DURATION: Three to four years

FUNDING AGENCY: DOE/ESTP.

COMENTS: Determine likely interactions among salt, brine; canisters, and waste at a range of temperatures and pressure that may be considered in disposal of high-level radioactive waste or spent fuel, and to determine the properties of resultant reaction products at temperatures up to $300^{\circ} \mathrm{C}$.

INFORMATION SOURCES FOR THIS PROJECT: DOE/TIC-11033 (draft) April 1980

REF.ID(S) OF ASSOCIATED DOCURENTS: DOE/RI-C/OWNI, USGS 
REF.ID - 37 CATEGORY - NEARFIELD, WASTE PACKAGE/GEOHEDIA INTERACTIONS

ROCK.TYPE - ROCK SALT

REF.TYPE - PROJECT - HIgh-Leve1-Haste-Container Interactions with Rock Salt and Brine

PRINCIPAL INVESTIGATORS: Molecke, M. A.; SLA

LOCATION: Contact: M. A. Molecke, 505-264-0781

DURATION: Three years

FUNDING ACENCY: DOE/ESTP.

COMENTS: Provide data and assess impacts of interaction potentials of high-level waste forms and containers with the WIPP geologic, near-field environment.

INFORHATION SOURCES FOR THIS PROJECT: DOE/TIC-11033 (draft) April 1980

REF.ID(S) OF ASSOCIATED DOCUMENTS: DOE/ALO/WIPP, SAND

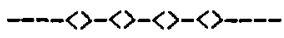

REF.ID - 38 CATEGORY - BRINE MIGRATION

ROCK.TYPE - SALT

REF.TYPE - PROJECT - Brine Migration

PRINCIPAL INVESTIGATORS: Shefelbine, H. C. (SLA); Lambert, S. J. (SLA); Sattler, A. R. (SLA); Roedder, E. (USGS)

LOCATION: Contact H. C. Shefelbire, 505-264-1926

DURATION: FOUI years

FUNDING AGENCY: DOE/ESTP.

COMENTS: Determine physicochemical properties of fluid inclusions in native rock and in artificially imposed heat flelds. To evaluate potential of fluid inclusions for waste form degradation and radionuclide migration by performing laboratory, bench-scale, and in-situ experiments for assessment of brfne migration phenomena.

INFORMATION SOURCES FOR THIS PROJECT: DOE/TIC-11033 (draft) April 1980

REF.ID(S) OF ASSOCIATED DOCUMENTS: DOE/ALO/WIPP, SAND, USGS

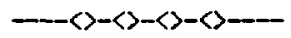


REF.ID - 39 CATEGORY - HOST ROCKS, SALT - THERHOHECHANIC STUDIES

ROCK.TYPE - ROCK SALT

REF.TTPE - PROJECT - Salt Kodel P111ar Studies

Location: Contant: G. Ra1nes, 614-424-7832

DURATION: Continuing

FUNDING AGENCY: DOE/ESTP.

COMENTS: Understand long-term creep behavior of salt as a function of temperature, Btress, and twe.

INFORMATION SOURCES FOR THIS PROJECT: DOE/TIC-11033 (draft) April 1980

REF.ID(S) OF ASSOCIATED DOCUMENTS: DOE/RL-C/ONWI, ORNL<smiles>CC=CC=CC=CC=CC</smiles>

REF.ID - 40 CATEGORY - WASTE/GEOMEDIA INTERACTIONS

ROCK.TYPE - TUFF

REF.TYPE - PROJECT - Tuff Study

PRINCIPAL INVESTIGATORS: Tyler, L. D. (SLA); Wolfsberg, K. (LASL), Contractors, NVO Support

LOCATION: Contact: Scott Sinnock, 505-264-2365

DURATION: Four years

FUNDING AGENCY: DOE/ESTP.

COAMENS: Develop and apply means to characterize near-field response of selected tuff units to simulated thermal, mechanical, chemical, and fluld conditions created by emplacement of high-level radioactive waste. Welded and nonwelded tuffs from the Nevada Test site will be studied in both laboratory and in situ environments.

INFORMATION SOURCES FOR THIS PROJECT: DOE/TIC-11033 (draft) April 1980

REF.ID(S) OF ASSOCIATED DOCUNENTS: DOE/NVO

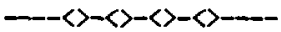


REF.ID - 41 CATEGORY - HOST ROCKS, ROCK SALT - IHERHOPHISICAL PROPERTIES

ROCK.TYPE - ROCK SALT

REF.TYPE - PROJECT - Thermal-Structural Interaction in SaltLaboratory Experiments

PRINCIPAL INVESTIGATORS: Wayland, J. R.; Wawerski, W., SLA

LOCATION: Contact: J. R. Way land, 505-264-7639

DURATION: Continuing

FUNDING AGENCY: DOE/ESTP.

COMMNTS: Provide thermophysical properties of WIPP rock salt and surrounding media and to obtain data on elastic and creep behavior to support cevelopient of appropriate constitutive models.

INFORMATION SOURCES FOR THIS PROJECT: DOE/TIC-11033 (draft) Apr1l 1980

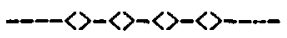

REF.ID - 42 CATEGORY - HOST ROCKS, THERMOMECHANICAL STUDIES

ROCK.TYPE - GRANITE

REF.TYPE - PROJECT - Material Propertes of Stripa Grante

PRINCIPAL INVESTIGATORS: Witherspoon, P. A., LBL

LOCATION: Contact: M. M. Lemcue, 614-424-5688

DURATION: Three years

FUNDING AGENCY: DOE/ESTP.

COMMNTS: Measurement of the material properties of carefully selected rock samples from the granite rock mass at the Stripa mine that are needed to understand the hydraulic, thermal, and rock mechanic behavior of the fractured rock mass.

INFORMATION SOURCES FOR THIS PROJECT: DOE/TIC-11033 (draft) APril 1980

REF.ID(S) OF ASSOCIATED DOCUMENTS: DOE/RL-C/ONWI, LBL

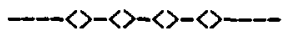


REF.ID - 43 CATEGORY - NEARPIELD, WASTE/GEOHEDIA INTERACTIONS

ROCK.TYPE - ARGILLITE

REF.TYEE - PROJECT - Argillite Study

PRINCIRAL INVESTIGATORS: Tyler, L. D. (SLA); Wolfsberg, K. (LASL)

LOCATION: Contact: Scott SInnock, 505-264-2365

DURATION: Sept. 1980

FUNDING AGENCY: DOE/ESTP.

COMMENTS: Characterize the near-field response of argillite to almulated thermal, mechanical, and chemical conditions created by emplacement of high-level radioactive waste.

INFORMATION SOURCES FOR THIS PROJECT: DOE/TIC-11033 (draft) APTII 1980

REF.ID(S) OF ASSOCIATED DOCURENTS: DOE/NVO, SAND, LA

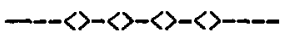

REF.ID - 44 CATEGORY - ENGINEERED BARRIERS, BOREHOLES, CEMENT

ROCK.TYPE - GENERAL

REF.TYPE - PROJECT - Borehole Plugging--Cement and Geochemical

PRINCIPAL INVESPIGATORS: Mather, K. (U.S. Army, Waterways

Experimental Station); Roy, D. M. (Penn. State Univ.)

LOCATION: Contact: F. L. Burns, 614-424-571

DURATION: Continuing

FUNDING AGENCY: DOE/ESTP.

COMMENTS: Develop a better basic understanding of the parameters that relate to placement and long-term stability of cementitious composities, to evaluate the geochemistry of cement-based materials, and to help determine longevity and durability of cementitious composities in repository environment.

INFORMATION SOURCES FOR THIS PROJECT: DOE/TIC-11033 (draft) Apri1 1980

REF.ID(S) OF ASSOCIATED DOCUMENTS: DOE/RL-C/ONWI

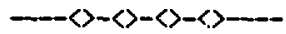


REF.ID - 45 CATECORY - ENGINEERED BARRIERS, BOREHOLES

ROCX.TYPE - BASALT

REF.TYPE - PROJECT - Borehole Plugging in Basalt

PRINCIPAL INVESTIGATORS: - -, RHO, Woodward-Clyde

LOCATION: Contact: H. J. Smith, 509-942-7782

DURATION: $1979-1992$

FUNDING AGENCY: DOE/ESTP.

COMENTS: Develop and demonstrate technology needed to effectively seal all man-made openings to a nuclear waste repository within the basalts of Columbia Plateau.

INFORMATION SOURCES FOR THIS PROJECT: DOE/TIC-11033 (draft) April 1980

REF.ID(S) OF ASSOCIATED DOCUMENTS: DOE/RI/WIPP, RHO

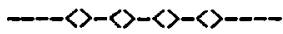

REF.ID - 46 CATEGORY - HOST ROCKS, DORE SALT

ROCK.TYPE - DOME SALT

REF.TYPE - PROJECT - Thermomechanical and Brine Migration In Situ Tests in Dome Salt at Avery Island

PRINCIPAL INVESTIGATORS: Krause, W., RE, SPEC

LOCATION: Contact: R. A. Cudnik, 614-424-4825

DURATION: Continuing

FUNDING AGENCY: DOE/ESTP.

COMENTS: Provide fleld engineering support to in situ tests at Avery Island Mine examining thermomechanical effects and brine migration in dome salt.

INFORMATION SOURCES FOR THIS PROJECT: DOE/TIC-11033 (draft) April 1980

REF.ID(S) OF ASSOUTATED DOCUEENTS: DOE/RL-C/ONWI

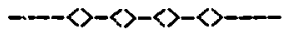


REF.ID - 47 CATECORY - IMTERHATIONAL PRGGRAMS, U.S./FRG -

ROCK.TKPE - DOKE SALT

REF.TIRE - PROJECT - U.S./Federal Republic of Germany (FRG) Cooperative Efforts in Asse

PRINCIPaL INVESTIGATORS:' Newby, D., Westinghouse, AESD

LOCATION: Contact: R. A. Robinson, 614-424-4172

DURATION: Continue until Salt Test Facflity becomes available.

FINDING AGENCY: DOE/ESTP.

COMMENT: Develop and perform field tests, inftially involving brine and gas migration waste/rock interaction, at the Asse Salt Mine, FRG, which has capabilities currently unavallable in U.S.

INFORMATION SOURCES FOR THIS PROJECT: DOE/TIC-11033 (draft) APr11 1980

REF.ID(S) OR ASSOCIATED DOCUMENTS: DOE/RL-C/ONWI

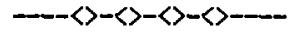

REF.ID - 48 CATEGORY - LAB TESTING - ROCK CORES, THERMOMECHANIC

ROCK.TYPE - GENERAL

REF.TYPE - PROJECT - U1tra-Large Rock Core Tests

PRINCIPAL INVESTIGATORS: W1therspoon, P. A., LBL

DURATION: Cont1nuing

FUNDING AGENCY: DOE/ESTP.

COMENTS: Perform lab testing to: 1) investigate effects of scale, state of stress, fluld pressure, and temperature on measured

properties of rocks and rock f1ssures; 2) conduct site-specific core cesting (i.e., Stripa, BWIP, NTS); and 3) investigate relationship between fissure permeability and dilatency due to shear loading.

INFORMATION SOURCES FOR THIS PROJECT: DOE/TIC-11033 (draft) APril 1980

REF.ID(S) OF ASSOCIATED DOCUMENTS: DOE/RL-C/ONWI, LBL

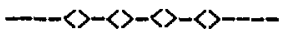


REF.ID - 49 CATECORY - IN SITU TESTING - DOST ROCKS, RASALT

BOCK.TYPE - BASALT

REF.TYPE - PROJECT - Near-Surface Test Facility Design, Construction and Operation

PRINCIPAL INVESTIGATORS: RHO

LOCATION: Contact: H. B. Dietz, 509-942-6881

DURATION: OCE. 1977 through Sept. 1982

FUNDING AGENCY: DOE/ESTP.

COMMENS: Design and construction of a multipurpose Near-Surface Test Facility for in situ testing of basalt.

INFORMATION SOURCES FOR THIS PROJECT: DOE/TIC-1I033 (draft) APIII 1980

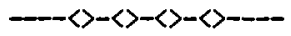

REF.ID - 5G CATEGORY - RADIONUCLIDE MIGRATION

ROCK.TYPE - GRANITE

REF.TYPE - PROJECT - Nucl1de Migration Studles in Fractured Granite: Climax, NTS

PRINCIPAL INVESTIGATORS: Coles, D., LLL

DURATION: Four years

FUNDING AGENCY: DOE/ESTP.

COMMNTS: Study radionuclide migration In fractured grante; compare in situ retardation factors with lab values; and model fracture flow in granite and calibrate the model using in situ values.

INFORMATION SOURCES FOR THIS PROJECT: DOE/TIC-11033 (draft) APIII 1980

REF.ID(S) OF ASSOCIATED DOCUMENTS: DOE/RL-C/ONHI, LLL

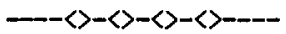




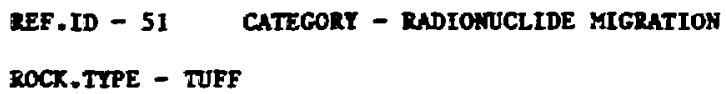

PRINCIPAL INVESTIGatoRs: Johnstone, K. (LASL), SLA, ANL

LOCATION: Contact: R. A. Robingon, 614-424-4172

DURATION: Four years

FUNDING AGENCY: DOE/ESTP.

COMMENS: Controlled field experiments to define radionuclide migration through tuffs; to determine whether available material properties and models are sufficlent to scale from laboratory to bench to field.

INFORMATION SOURCES FOR THIS PROJECT: DOE/TIC-11033 (draft) April 1980

REF.ID(S) OF ASSOCIATED DOCUMENTS: DOE/RL-C/ONWI, SAND, ANL

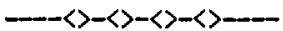

REF.ID - 52 CATEGORY - NATURAL ANALOGUES, OKLO

ROCK. TYPE - GENERAL

REF.TYPE - PROJECT - Natural Fission Reactor Program, Oklo

PRINCIPAL INVESTIGATORS: Cowen, G., LASL

DURATION: Three years

FUNDING AGENCY: DOE/ESTP.

COMIENTS: Identify migration paths of some of the mobile fission products and reconstruct paleohydrology and transport history.

INFORMATION SOURCES FOR THIS PROJECT: DOE/TIC-11033 (draft) APr11 1980

REF.ID(S) OF ASSOCIATED DOCUMENTS: DOE/RL-C/ONWI

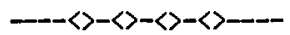


2EF.ID - 53 CATEGORY - MODELIM, MASS TRATPSORT

ROCK.TYPE - GENERAL

REF.TYPE - PROJECT -

Geochenical Study for Verification of Complex

Solute Transport Hodels

PRINCIPAL INVESTIGATORS: Grove, D. B., USGS

LOCATION: Contact: G. D. DeBuchananne, 703-860-6976

DURATION: Continuing

FINDING AGENCY: DOE/ESTP.

COMMENS: Select field sites suitable for obtaining data on substantial number of chemical reactions and attempt to verify complex nonconservative solute-transport models of the type that would be useful in studying potential waste disposal sites. Sites where leaching of uranium is occurring are most promising in yielding such data. One of the sites used in the project is near Casper, Wyouing, where U.S. Bureau of Mines is doing uranium leaching experiments. Data from this site and others will be used in the project.

INFORMATION SOURCES FOR THIS PROJECT: DOE/TIC-11033 (draft) April 1980

REF.ID(S) OF ASSOCIATED DOCUMENTS: USGS

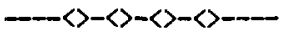

REF.ID - 54 CATEGORY - MASS TRANSPORT

ROCK.TYPE - GENERAL

REF.TYPE - PROJECT - Mechanistic Studies of Trace Constituent Sorption and Migration in Geologic Media

PRINCIPAL INVESTIGATORS: RaI, D., PNL

DURATION: Continuing

FUNDING AGENCY: DOE/ESTP.

COMENTS: Study chemical migration in rocks.

INFORMATION SOURCES FOR THIS PROJECT: DOE/TIC-11033 (draft) APril 1980

REF.ID(S) OF ASSOCIATED DOCUMENTS: DOE/OBES, PNL

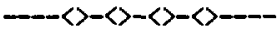




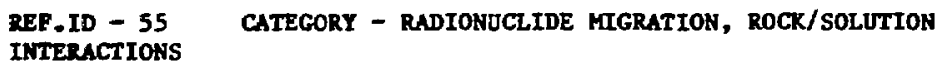

PRINCIPAL INVESTIGATORS: Fortney, D. R.; Dosch, R. G., SLA

LOCATION: Contact: D. R. Fortney 505-264-5576

DURATION: Three years

FUNDING AGENCY: DOE/ESTP.

COMANTS: Determine sorptive capacities for radionuclides in rock/solution systems of southeastern New Mexico and perform assessment of radionuclide migration modeling.

INFORMATION SOURCES FOR THIS PROJECT: DOE/TIC-11033 (draft) Apr11 1980

REF.ID(S) OF ASSOCIATED DOCUNENTS: DOE/ALO/WIPP, PNL, SAND

REF.ID - 56 CATEGORY - AGE DATING, GROUNDWATER

ROCK . TYPE - NA

REF .TYPE - PROJECT - Ground-water Dating

PRINCIPAL INVESTIGATORS: SRL, (Helium); U. of Ar1zona (Chlorine); LBL (Uranium)

DURATION: Continuing with emphasis on application

FUNDING AGENCY: DOE/ESTP.

COMENTS: Develop methods of dating ground water older than 50,000 years. This capability would provide information on past rates of ground-water flow in vicinity of repository and ald in verification of predictive models used for determing future of ground-water flow.

INFORMATION SOURCES FOR THIS PROJECT: DOE/TIC-11033 (draft) Apr1l 1980

REF.ID(S) OF ASSOCIAT:D DOCUMENTS: DOE/RL-C/ONHI, LBL, SAND

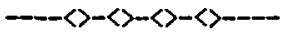


REF.ID - 57 CATEGORY - AGE DATIKG

ROCK.TYPE - GENERAL

REF.TYPE - PROJECT - Geochronology

PRINCIPAL INVESTrAATORS: Doe, B., USGS

LOCATION: Contact: E. R. Roseboom, 703-860-6631

DURATION: Continuing

FUNDING AGENCY: DOE/ESTP.

COMENTS: Develop new methods to determine ages of rocks, ground water, and events.

INFORMATION SOURCES FOR THIS PROJECT: DOE/TIC-11033 (draft) Apr1I 1980

REF.ID(S) OF ASSOCIATED DOCUMENTS: USGS

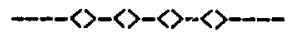

REF.ID - 58 CATEGORY - SITE CHARACTERIZATION, ROCK/SOLUTION INTERACTIONS, SE NEW MEXICO

ROCK.TYPE - SALT, OTHER

REF.TYPE - PROJECT - Characterization of Southeastern New Mexico Rocks and Waters

PRINCIPAL INVESTIGATORS: Lambert, S. J., SLA

DURATION: Continuing

FUNDING AGENCY: DOE/ESTP.

COMENTS: Obtain basic geochemical data on subsurface materials in southeastern New Mexico for brine migration, radionuclide sorption, and borehole plugging studies and to determine history of rock/solution interaction.

INFORMATION SOURCES FOR THIS PROJECT: DOE/TIC-11033 (draft) Apri. 1980

REF.ID(S) OF ASSOCIATED DOCUNENTS: DOE/ALO/WIPP, SAND

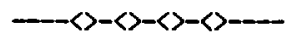


REF.ID - 59 CATEGORY - MODELING, WASTE PACKAGE/GEOMEDIA
INTERACTIONS

ROCK.TYPE - GENERAL

REF.TYPE - PROJECT - Chemical Environment Modeling

PRINCIPAL INVESTIGATORS: RHO, LBL

LOCATION: Contact: M. J. Smith, 509-942-7782

DURATION: Oct. 1978 through Sept. 1984

EUNDING AGENCY: DOE/ESTP.

COMMNTS: Characterize chemical environment in the vicinity of the buried waste packages as a function of time. Long-range predictions of potentially mobile radionuclide material in the near field can be utilized in conjunction with hydrologic flow lnformation to produce a model which quancitatively assesses biohazard potential as a function of distance or time from emplacement.

INFORMATION SOURCES FOR THIS PROJECT: DOE/TIC-11033 (draft) APril 1980

REF.ID(S) OF ASSOCIATED DOCUNENTS: DOE/RL/BWIP, RHO, LBL

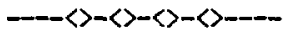

REF.ID - 60 CATEGORY - MODELING, MASS TRANSPORT

ROCX.TYPE - NA

REF.TYPE - PROJECT - Solution of Solute Transport Equations

PRINCIPAL INVESTIGATORS: GrOVE, D. B. (USGS)

LOCATION: CONTACT: G.D. DeBuchananne, , J3-860-6976

DURATION: Continuing

FUNDING AGENCY: DOE/ESTP.

COMENTS: Seek new methods to solve the partial differential

equations that define flow and reaction of mass through porous media.

INFORMATION SOURCES FOR THIS PROJECT: DOE/TIC-11033 (draft) APril 1980

REF.ID(S) OF ASSOCIATED DOCUNENTS: USGS

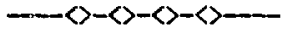


REF.ID - 61 CATEGORY - MODELIHG, RADIONUCLIDV TRANSPORT

ROCK.TYPE - GENERAL

REF.TYPE - PROJECT - Lvelopment of Analytical Transport Models

PRINCIPAL INVESTIGATORS : " ford, T., LBL

LOCATION: Contact: H. C. Burkholder, 614-424-7834

DURATION: Four years

FUNDING AGENCY: DOE/ESTP.

COMMENTS: To provide analytical standards capability for the calculation of radionuclide transport in porous media and apply it in support of performance assessment activities of NWTS program.

INFORMATION SOURCES FOR THIS PROJECT: DOE/TIC-11033 (draft) AprII 1980

REF.ID(S) OF ASSOCIATED DOCUMENTS: DOE/RL-C/ONWI, LBL

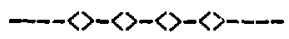

REF.ID - 62 CATEGORY - MODELING, BR-AE MIGRATION, ROCK/SOLUTION INTERACTIONS

ROCK. TYPE - ROCK SALT

REF.TYPE - PROJECT - Brine Migration Modeling

PRINCIPAL INVESTIGATORS: Olander, D. (UCB)

LOCATION: CONTACT: J. F. KIrcher, 614-424-4871

DURATION: Continuing

FUNDING AGENCY: DOE/ESTP.

COMMENTS: Develop a comprehensive model of brine migration in natural rock salt.

INFORMATION SOURCES FOR THIS PROJECT: DOE/TIC-11033 (draft) ApriI 1980

REF.ID(S) OF ASSOCIATED DOCUMELTS: DOE/RL-C/ONWI

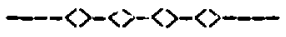


REF.IV - 63 CA'TEGORY - MODELING, MASS TRAKSPORT

ROCK.TYPE - GENERAL

REF.TYPE - PROJECT - Solute Transport in the Unsaturated Zone

PRINCIPAL INYESTIGATORS: RubIn, J., JSGS

LOCATION: Contact: D. G. DeBuchananne, 703-860-6976

DURATION: Continuing

FUNDING AGENCY: DOE/ESTP.

COMENTS: Develop data-based laboratory- and fleld-tested models useful for predicting transport of waste nuclides in the unsaturated zone. The models must include particular effects of water content upon dispersion and selected chemical processes during seepage of solutions through water-unsstirated sediments.

INFORMATION SOURCES FOR THIS PROJECT: DOE/TIC-11033 (draft) April 1980

REF.ID(S) OF ASSOCIATED DOCUMENTS: USGS

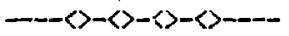

REF.IL - 64 CATEGORY - SITE EVALUATION

ROCK. TYPE - SAL'T

REF.TYPE - PROJECI - N Nolear Waste Repository Safety Assesatient

PRINCIPAL INVESTIGATORS: Jrannen, J. P. (SLA); Tierney, M. S. (SLA)

T.OCATION: CONTACT: J. P. Brannen, 505-264-1280

DURATION: Continuing

FUNDING AGENCY: DOE/ESTP.

COMRENT: To provide a WIPP site-specific assessment of long-range consequences of enplacement of nuclear wastes in Salado salt formation.

INFORMATION SOURCES FOR THIS PROJECT: DOE/TIC-11033 (draft) Apri1 1980

REF.ID(S) OF ASSOCIATED DOCUMENTS: DOE/ALO/WIPP, SAND 

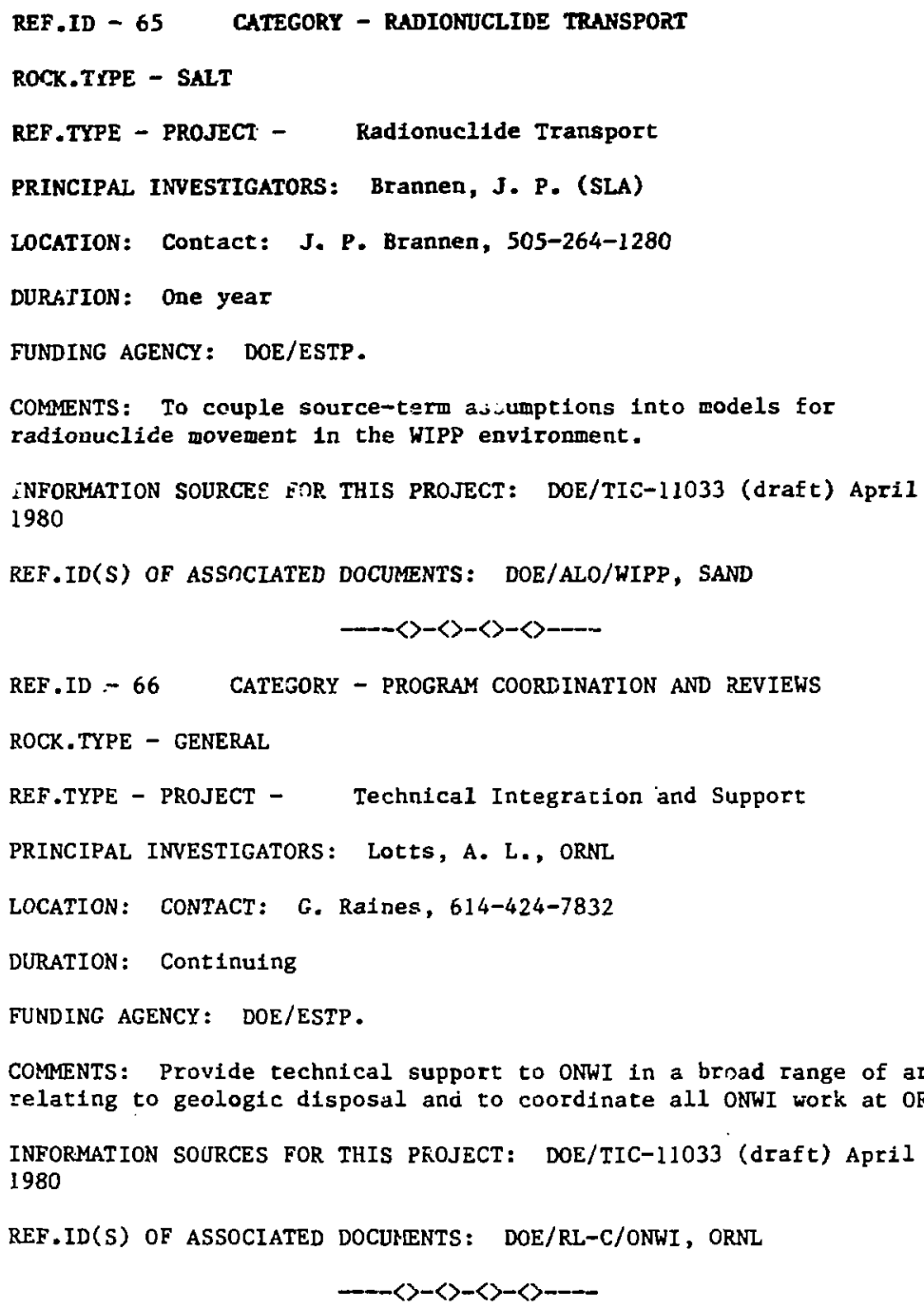
REF.ID - 67 CATEGORY - PROGRAM COORDINATION AND REVIEUS

BOCK.TYPE - GENERAL

REF.TYPE - PROJECT - NWWSI (Nevada Nuclear Waste Storage Investigetions), Technical Project Coordination

PRINCIPAL INVESTIGATORS: Lincoln, R. C.; Tylet, L. D. (SLA); Twenjofel, W. S., and D1xon, G. L. (USGS); Wolfsberg, K., Crowe, B. H. (LASL); Ramspott, L. D. (LLL)

LOCATION: Contact: Scott Sinnock, 505-264-2365

DURATION: COntinuing

FUNDING AGENCY: DOE/ESTP.

COMMENT: Provide coordination and integration of NNWSI technical Investigations; to assure approprlate exchange of information among NNWSI contractors; to exchange information with other aspects of the NWTS Program; and to advise LOE on technical merits of Investigative activities in terms of progress toward a capability for reposttory construction.

INFORMATION SOURCES FOR THIS PROJECT: DOE/TIC-11033 (draft) April 1980

REF.ID(S) OF ASSOCIATED DOCUKENTS: DOE/NVO, SAND, USGS, LLL

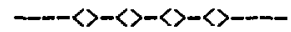

REF.ID - 68 CATEGORY - PROGRAM COORDINATION AND REVIEWS

ROCK.TYPE - GENERAL

REF.TYPE - PROJECT - Geological Exploration Review Group

PRINCIPAL INVESTIGATORS: Hambelton, W. W.; Remson, I.; Bloom, A. L.; Ross, H.; Smith, C. I.

LOCATION: CONTACT: R. B. Laughon, 614-424-4267

DURATION: Continuing

FUNDING AGENCY: DOE/ESTP.

COMANTS: Provide Independent evaluation of ONWI Geologic Exploration Program.

INFORMATION SOURCES FOR THIS PROJECT: DOE/TIC-11033 (draft) April 1980

REF -ID(S) OF ASSOCIATED DOCUMENTS: DOE/RL-C/ONWI, ONWI 


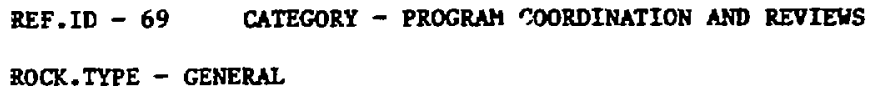

REF.ID(S) OF ASSOCIATED DOCUMENTS: DOE/RL-C/ONWI

$$
---\langle\rangle-\langle\rangle-\langle\rangle-\langle\rangle-
$$

REF.ID - 70 CATEGORY - ROCK/SOLUTION INTERACTIONS THERMOMECHANICAI STUDIES

ROCK.TYPE - GENERAL

REF.TYPE - PROJECT - Reservoir Dynamles Related to Nuclear Waste Storage

LOCATION: P- son in charge: P. A. Witherspoon, Geosçiences Program, LBL

FUNDING AGENCY: DOE.

COMMNTS: Heat released by radioactive decay of Nuclear waste in an underground repository causes long-term thermal disturbance in the fluid flow in fractured rock mass of repository. Studies in regional thermally induced convection around and above the repository in the rock mass are being made.

INFORMATION SOURCES FOR THIS PROJECT: DOE/ER-0071 (AUg. 1980)

REF.ID(S) OF ASSOCTATED DOCUNENTS: LBL 
REF -ID - 71 CATEGORY - ROCK/SOLUTION INTERACTIONS, RADIONUCLIDE
TRANSPORT

ROCK. TYPE - GENERAL

REF.TYPE - PROJECT - Rock-Water Interactions

PRINCIPAL INVESTIGATORS: ApPs, J. A., LBL

LOCATION: Person in charge: P. A. Witherspoon, Geosciences progran, LBL

FUNDING AGENCY: DOE.

COMENTS: The project is designed to elucidate chemical reactions between common rock-forming minerals and aqueous phase under subsurface conditions. The results will help determine mechanisms responsible for chemical changes in rocks saturated with groundwater, particularly with regard to processes operating in geotbermal reservoirs and during mass transport of radionuclides in water-saturated rocks.

INFORMATION SOURCES FOR THIS PROJECT: DOE/ER-0071 (Aug. 1980)

REF.ID(S) OF ASSOCIATED DOCUMENTS: LBL<smiles>C=C=CC=CC=CC</smiles>

REF.ID - 72 CATEGORY - MODELING, MASS TRANSPORT

ROCK. TYPE - GFNERAL

REF.TYPE - PROJECT - Chemical Transport in Natural Systems

LOCATION: Person In charge: P, A. Witherspoon, Geosclences Program, LBL

FUNDING AGENCY: DOE.

COMMENTS: Develop conceptual models of solute transport in natural flow systems, using chemical reactions based on thermodynamic concepts applicable to irreversible (or non-equilibrium) processes. Concurrently with the theoretical studies, experimental studies of sorption of cesium lons and uranyl lons on surfaces of a smectite clay and on silica are belng conducted. Objectives are to determine thermodynamic properties of sorption processes and evaluation of significance of kinetic effects durting sorption.

INFORMATION SOURCES FOR THIS PROJECT: DOE/ER-0071 (Aug - 1980)

REF.ID(S) OF ASSOCIATED DOCUMENTS: LBL 
REF.ID - 73 CATECORY - HASS TRANSPORT

ROCX.TYPE - NA

REF.TYPE - PROJECT -

Thermodynanics, Kinetics and Trausport in Aqueous Electrolyte Solution:

PRINCIPAL INVESTIGaTORS: Milet, D. G.; Wolery, T. J,

LOCATION: Person in charge: R. N. Schock, Geosciences, Lawrence Livermore Laboratory

FUNDING AGENCY: DOE.

COMENTS: Study mechanism and kinetics of selected geochemical processes, especially those involving the isolation of radioactive wastes. Diffusion and osmotic coefficients of certain electrolyte solutions are being measured, and computer equilibrium codes to predict speciation, solubility, and reactions in various mineral solution systems are being developed.

INFORMATION SOURCES FOR THIS PROJECT: DOE/ER-0071 (Aug. 1980)

REF.ID(S) OF ASSOCIATED DOCUMENTS: LLL

REF.ID - 74 CATEGORY - INTERNATIONAL PROGRAMS, USSR

FOCK.TYPE - SALT, GRANITE, OTHER

REF.TYPE - PROJECT - USSR, Radioactive-Waste Management Program

COMENTS: For a number of years, USSR has practiced disposal of non-HLW by lajection of liquids into deep, porous strata. They are evaluating geologic disposal of solid wastes in salt, granite and sandstone formations. Activities include criteria development, reposftory design and engineering, testing of prototype and studies of bulk rock behavior.

INFORHATION SOURCES FOR TUIS PROJECT: TID-29442, 1979, P. G-10, and PNL-3333, March 1980, p. 79.<smiles>CC=CC=CC=CC</smiles> 
REF.ID - 75 CATECORY - INTERHATEOHAI PROGRLYS, BELGIOH

ROCK.TYPE - CLAY

REF.TYPE - PROJECT - Belglun, Radloactive Waste Managenent Progran

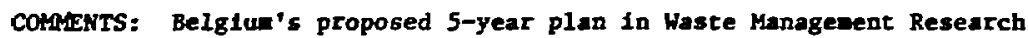
and Development (1978-1982) includes work to be done mostly under the frawework of the Comission of Europtan Communties. With cc-sponsorship of OEC, Belgium is developing clay repository technology (site and nedia characterization, corrosion effects, repository design, risk analysis and in situ tests) and intends to have a test repository operational at Mol by 1983. Evaluation of preliminary tests indicates that tunnels and underground facilities can be constructed in the Boon clay formations at Mol, at depths up to $250 \mathrm{~m}$, and that a thermal load of about $15 \mathrm{kw}$ per hectare can be tolerated. Heater experiments and the construction of a test chamber ( $350 \mathrm{~m}$ long by $30 \mathrm{~m}$ wide) under the Mol site are planned.

INFORMATION SOURCES FOR THIS PROJECT: TID-29442, 1979, P. G-9 and PNL-3333, March 1980, PP. 23-26.

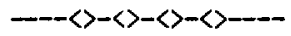

REF.ID - 76 CATEGORY - INTERNATIONAL PROGRAMS, SWEDEN

ROCK.TYPE - GRANITE

REF.TYPE - PROJECT - Sweden, Karn-Bransle-Sakerket (KBS): Nuclear Fuel Safety Project

LOCATION: Karn Bransle Sakerhet, Box 5864, s102, 48 stockholm. Sweden

DURATION: Since 1977

COMMETS: Project begun as result of Sweden's Stipulation Law passed in April 1977. U.S. has bilateral agreement with Sweden for linited scope cooperative program in field-iesting experiments and in techniques related to measuring fluld movement through fractures in a granite rock. system, utilizing the Stripa Mine in Sweden. These results will provide data useful for evaluating U.S. granite as a terminal storage repository.

INFORMATION SOURCES FOR THIS PROJECT: TID-29442, p. G-9 1979

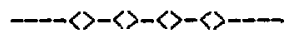


BEF.ID - 77 CATECORY - INTEPHATIOMAL PROGRAHS, JAPAN

ROCK.TYPE - GRANIIE, TUFF, SHALE

REF.TYPE - PROJECT - Japan, Radioactfve Naste Managenent Progran

PRINCIAL INVESTIGATORS: Atonic, Energy Bureau of Japan

DURATION: SInce etd-1970's

COMENTS: Japanese Atomic Energy Research Institute, under subcontract with Mitsubishi Metals Corp., 1s making survey of potential sites in Japan. Graaite, basalt, zeolitic tuff, shale and diabase are 1dentified as possible host rocks. Japan 18 also considering seabed as potential sites. Japan plans to begin geologic disposal demonstration tests in 1985, and have a licensed industrial scale repository for TRU and high level wastes by 2000 .

INFORMATION SOURCES FOR THIS PROJECT: TID-29442, 1979, P. G-6 and PNL-3333, March 1980, p. 58

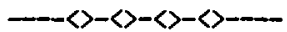

REF.ID - 78 CATEGORY - INTERNATIONAL PROGRAMS, FRANCE

ROCK.TYPE - GRANITE, SALT, OTHER

REF.TỲPE - PROJECT - France, Radioactive Waste Management Program

COMMENTS: The planned disposal method is emplacement in deep geologic formations. Those presently under study are rock salt and crystalline. Disposal in granite has been evaluated for the site at La Hague, and plans are underway to evaluate a number of crystalline sites. France is also contributing to studies on seabed disposal. The target date for first pilot plant repository (alpha-tearing waste only) is 1985.

INFORMATION SOURCES FOR THIS PROJECT: TID-29442, p. G-4, and PNL-333, March 1980, Pp. 41-43 
REF.ID - 79 CATECORY - INTEDATIONAL PROGRAYS, UK

IOCK.TMPE - GRANITE, OTHER

REF.TYPE - PROJECT - United KIngdon, Radioactive Waste Hanagenent Progren

COLEENTS: UR plans to provide waste repository for high-level and alpha-bearing wastea. Options inclide land, seabed, and sub-seabed disposal. Milestones include selecting the site for a repository, 1984; starting a pllot disposal operation with radioactive glass, 1992; and operation of the repository, 2000. Project participants include the Department of the Environeent, Institute of Geologic Sclences, and AERE-Harwell. S1tes selected for exploratory drilling and In situ investigetions include crystalline rock, argiliaceous and evaporite formations. A conceptual design for a reposirory in hard rock has been prepared. The preferred site will be selected in 1984, when decision will be made between seabed and deep geological

disposal sites.

INFORMATION COURCES FOR THIS PROJECT: TID-29442, 1979, p. G-3, and PNL-333, March 1980, p. 76 .

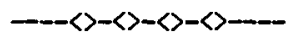

REF.ID - 80 CATEGORY - INTERNATIONAL PROGRAMS, CANADA

ROCK. TYPE - SALT, GRANITE

REF.TYPE - PROJECT - Canada, Radloactive Waste Management Program

LOCATION: Atomic Energy of Canada Limited, Whiteshell Nuclear

Research Establishment, PInawa, Manitoba ROe lLO

COMENTS: Continued effort in a studying salt technology and investigating granite formations as potentlal storage sites. Many potential repository sites have been located, most of them in granite formatiuns in the Precaubrain shleld of Ontarto province. A test site has been established in a small granific body at white Lake to permit testing equipment and concepts. Research drilling had begun at Atikokan, Ontarlo, to test rock formations for posstble disposal. sites. Areas of major research and development emphasis include repository site characterization, radionuclide migration, hydrology, thermal and mechanical properties of rock formations, repository design and borehole plugging.

INFORMATION SOURCES FOR THIS PROJECT: TID-29442, 1979, P. G-5 and PNL-3333, March 1980. PP. 32-34

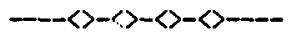


REF.ID - 81 CATEGORY - InTERNATIOLAL PROGRAYS, FRG

ROCK.TYPE - DOHE SALT, OTHER

REF.TYPE - PROJECT - Gerany, Radiaactive Waste Managenent Progran

COMANTS: Since 1965, FRG has focused waste disposal technology research on work at the Asse salt aine. The alne recelves wastes on a routine basis wuch like a scaled-down version of pilot plant for DOE defense waste in New Mexico. The wne has been used for large-acale experimental disposal of low-and interwediate-level wastes. R\&D activities have Included development of cavern construction technology, testing of various techniques for placing waste containers in repositories, rock mecharics studies, in situ measurements of thermal and hydrologic parameters and safety analyses. U.S. participation In Asse experiments will be carried out by Westinghouse AESD, consisting of experiments in brine and gas migration, tests developed from previous work at Avery Island and Asse, and waste/host rock interaction tests.

INFORMATION COURCES FOR THIS PROJECT: PNL-3333, March 1980, Pp. 43-48, INTERDISCIPLINARY SCIENCE REVIEW, V. 5, No. 4, PP. 292-303, DOE/TIC-11033 (draft), Arp11 1980, p. D-65.

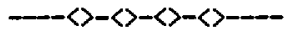

REF.ID - 82 CATEGORY - HOST ROCKS, REFERENCE REPOSITORY

CONDITIONS

ROCK.TYPE - SAIT, BASAIT, TUFF, GRANITE, OTHER

REF.TYPE - PROJECT -

Reference Repository Conditions Interface

Working Group (RRC-IWG)

PRINCIPAL INVESTIGATORS: Ralnes, G. E. Members are:, Chafrman, ONWI;, Blbler, N. E., SRL, Defence, Cla1borne, H. C., ORNL, Salt Repository Envi ronment, Hooplngarner, K. R., Rockwell (BWIP), Basalt, Hubbard, N., ONWI, Geochemical envíronment, Hunter, T. O., SNI (WIPP), Salt. Lynch, R. W., SNL (NNWSI), tuff, McElroy J. L., PNL, Commercial high-level waste, Osnes, J. D., RE, SPEC, Granite, Rickertsen, L. D., SAI, Shale.

COMMENTS: Develop reference repoisttory conditions to serve as guide for: a) scientists conducting material performance test, b) englineers preparing design of repositorles, c) technicaliy conservative conditions to be used as basis for DOE 11 cense applications, and d) scientists and engineers developing waste forms. Present plans call for completion of generic reference repository conditions for salt, basalt, tuff, and granite by Dec. 1981. Shale has been assigned a lower priority and RRC work on this rock type has been discontinued. lovever, interim conditlous for all five rock types will be published as O'sWI reports in the near future. 
IMFCUMATION SOURCES FOR THIS PROJECT: Preprints, -Developwent of Reference Conditions for Geologic Repositorles for Nuclear Waste in the USA", paper presented at Materials Research Society, annual beeting, boston, Ma., Nov. 1980. (Raines, G. E., OKHI)

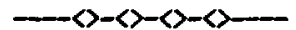

REF.ID - 83 CATEGORY - RESEARCH PROGRAYS, U.S.

ROCK. TYPE - GENERAL

REF.TYPE - PROJECT - ESTP (Earth Science Technical Plan for Disposal of Radioactive Waste in a Mined Repository)

PRINICPAL INVESTIGATORS: WunderIlch, R., DOE RIchland Operations, Columbus, MacCregor, I., DOE-HQ, Sinnock, S., Sandia, NNWSI, Cooley, C., DOE-HQ, Dudley, W., USGS, NNWSI (Nevada), Duguid, J., Battelle, ONWI, Evans, G., Rockwell-Hanford, Basalt Waate Isol. Proj., Klingsberg, C., DOE-HQ, Iincoln, R., Sandia, NNWSI, MacGregor, I., DOE-HQ, Roseboom, E., USGS, Schnetder, R., USGS, Sinnock, S., Sandia, NNSI, Stewart, D., USGS, Stevens, P., USGS, Trask, N., USGS Weart, W., Sandla, WIPP.

FUNDING AGENCY: DOE/ESTP.

COMENTS: Identification of four or flve potential sites, redirection of research from generic to site specific characterization, resolution of related technical questions, and preparation of a detalled plan by each conponent of NWTS Program.

INFORMATION SOURCES FOR THIS PROJECT: DOE/TIC-11033 (draft) April 1980 
REF.ID - 84 CATEGORY - U.S. PROGRAMS, WRIT

ROCK.TYPE - GENERAL, OTHER

REF.TYPE - PROJECT - WRIT (Waste/Rock Interactions Technology)

PRINCIPAL INVESTIGatoRS: Serne, R. J., Proj. Manager

LOCATION: Pacifıc Northwest Laboratory, Richland, Wash, 99352

DURATION: Continaing

FUNDING AGENCY: DOE/Battelle.

COMMENS: Geochemical investigations of mechanisms that control radionuclide behavior in their interactions with geologic media and with engineered barriers. Areas of Investigations during FY 1980 . include leach mechanisms, rock-radionuclide retardation studies, solution chemistry, waste package tests, and computer modeling. During FY 1981, WRIT research plans will cover these areas: 1) Computer predictor codes: complete prototype nuclide release, leaching and thermodynamic computer predictor codes; use these to help interpret experimental data to assist NWTS safety assessment. Verify these models through lab studies, compare results with field data when avallable. 2) NWTS waste plans (waste package plan, site characterization, and selection plan): Input to these plans, work with the two NWTS radionuclide field experiment as preparation for comparisons of WRIT lab results to the field results when available. 3) Waste-form leaching and nuclide sorption: Compile and evaluate past data; continue studies on mechanisms that control waste-form leaching and nuclide sorption; complete studies on solubility, of actinide oxides under air-equilibrated conditions; establish practical ways to control reducing Eh values in lab experiments; establish useful methods for waste- package performance evaluation and dynamic sorption tests on intact core materials. 4) Initiate $U$ and Th disequilibrium studies on field sapples.

INFORMATION SOURCES FOR THIS PROJECT: WRITE, Tech. PIOg. Plan, FY-8i, June 1980 
REF.ID - 85 - CATEGORY - RADIONUCLIDE TRANSPORT

ROCK.TYPE - GENERAI

REF.TYPE - PROJECT - Mobility of Radioactive Waste Materials in Subsurface Migration by Particulate Transport

PRINCIPAL INVESTIGATORS: Georgia, Inst. of Technology

DURATION: FY 1978

FUNDING AGENCY: NRC.

INFORMATION SOURCES FOR THIS PROJECT: DOE/EDP-0064 (Sept. 1980)

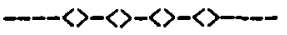

REF.ID - 86 CATEGORY - SITE TECHNOLOGY

ROCK.TYPE - BASALT

REF.TYPE - PROJECT - High Level waste Site Technology

PRINCIPAL INVESTIGATORS: Rockwe1l, Hanford Operations

DURATION: Continuing

FUNDING AGENCY: DOE.

INFORMATION SOURCES FOR THIS PROJECT: DOE/EDP0064 (SePt. 1980)

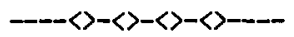

REF.ID - 87 CATEGORY - U.S. PROGRAMS, WIPP

RDCK. TYPE - SALT

REF.TYPE - PROJECT - WLPP (Waste Isolation Pilot Plant)

DURATION: COntinuing

FUNDING AGENCY: DOE/NRC.

COMENTS: WIPP- Los Medanos site, Eddy County, New Mexico, a facility for the demonstration of disposal of TRU only and for research and development with high level wastes. Studies at WIPP include laboratory tinvestigations, bench-scale studies in iarge block of salt, a series of preliminary measurements in existing mines, and development of anzlytical models for predicting the behavior of a repository. For detailed summary description, see Chap. 8 of DOE/EIS-0026 (OCt. 1980).

INFORMATION SOURCES FOR THIS PROJECT: DOE/EIS-0016 (OCT. 1980)

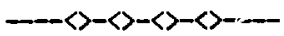


REF.ID - 88 CATEGORY - RESEARCH PROGRAMS, U.S.

ROCK.TYPE - SALT

REF.TYPE - PROJECT - Evaluation of Scientific and Technical

Aspects of Certain Programs Involving the Management of Radioactive Wastes

PRINCIPAL INVESTIGATORS: National Academy of Sciences

DURATION: 1955-

FUNDING AGENCY: NRC.

COMMENTS: NAS was one of the earliest group involved with research in underground disposal of radioactive waste. In 1955, AEC asked a committee of NAS to examine the issue of permanent disposal of radioactive waste. The joint conclusion of NAS and NRC (1957) was that 'the most pronising method of disposal of high-level waste was in salt deposits'. They recommended salt for further evaluation because of its thermal and physical properties. This led to several studies that consider salt as potential sites. 1980 .

INFORMATION SOURCES FOR THIS PROJECT: DOE/EIS-0026 (OCL. 1980)

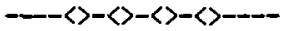

REF . ID - 89 CATEGORY - WASTE PACKAGE PERFORMANCE

ROCK.TYPE - GENERAL

REF.TYPE - PROJECT - Monitoring Waste Package Condition

PRINCIPAL INVESTIGATORS: TBD, (will be coordinated with DOE, USGS, Bureau of Mines)

DURATION: FY 1982

FUNDING AGENCY: NRC.

COMMENT: Determine critical parameters that describe waste package performance in a repository. Assess and test methods for monitoring parameters and waste package performance during operation of the repository and during the period of potential waste retrieval. Assess compatibility of package design and placement with proposed monitoring methods.

INFORLATION SOURCES FO" THIS PROJECT: NRC WASTE MANAGEMENT PKOGRAM FOR ACRS PRESENTATION, June 22, 1981.

REF.ID(S) OF ASSOCIATED DOCLIENTS: NUREG

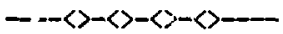


REF.ID - 90 CATEGORY - BACKFILLS

ROCK.TYPE - GENERAL

REF.TYPE - PROJECT - Performance of Backf111 materials

PRINCIPAL INVESTIGATORS: UNDES, (In conjunction with in situ measurement verification to be accomplished in underground facilities under Fin B3038 by Lawrence Berkeley Laboratory)

DURATION :

FUNDING AGENCY: NRC.

COMMENS: Evaluate types of backfill and methods of emplacement in excavated underground spaces. Assess mechanical and hydrological properties of backfills and effects of incomplete backfilling on fracturing and long-term containment capability. Assess effects of potential mineralogical and structural changes due to long-term underground conditions (e.g., temperature pressure, and radiation). Include consideration of mechanical properties resulting from the Inclusion of components needed to assure chemical retardation of radionuclides. Test backfills in avallable underground facilities, including test chambers excavated by different methods to evaluate effects of fracturing.

INFORMATION SOURCES FOR THIS PROJECT: NRC WASTE MANAGEMENT PROGRAM FOR ACRS PRESENTATION, June 22, 1981.

REF.ID(S) OF ASSOCIATED DOCUMENTS: NUREG

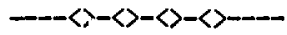

REF .ID - 91 CATEGORY - SIMULATION, WASTE/SOLUTION INTERACTIONS

ROCK.TYPE - NA

REF.TYPE - PROJECT - Effects of Complexation of Metal Ions by Monobutyl and Dibutyl Phosphate in Simulated Nuclear Waste Solution

PRINCIPAL INVESTIGATORS: Bow1s, State College

DURATION: FY 1981

FUNDING AGENCY: NRC.

COMENTS: Deterwine the nature and extent of complexation of metal ions by monobutyl phosphate and dibutyl phosphate. Identify mechanism by which monobutyl phosphate and dibutyl phosphate complex prominent metal ions $\$ n$ simulated waste tank environment. Determine effects of pH on conplexation and resulting sludge formation.

INFORYTION SOURCES FOR THIS PROJECT: NRC WASTE MARAGEMENT PROGRAM FOR ACRS PRESENTATION, June 22, 1981. 
REF.ID - 92 CATEGORY - RESEARCH PROGRAMS, U.S.

ROCK.TYPE - BEDDED SALT

REF.TYPE - PROJECT - Risk Methodology Development for Waste

Isolation in Bedded Salt

PRINCIPAL INUESTIGATORS: NRC

DURATION: FY 1981

FUNDING AGENCY: NRC.

COMMENTS: To provide Nureg reports describing the development and application of risk assessment methodology for waste isolation in bedded salt. To demonstrate application of methodology in evaluating specific repository sites and in showing compliance with the EPA standards and with 10-CFR-60. Plan to produce eighteen NUREG reports documenting methodology and its application, ten published papers, six computer models with user manuals.

INFORMATION SOURCES FOR THIS PROJECT: NRC WASTE MANAGEMENT PROGRAM FOR ACRS PRESENTATION, June 22, 1981 .

REF.ID(S) OF ASSOCIATED DOCUMENTS: NUREG

REF.ID - 93 CATEGORY - IN SITU TESTING - HOST ROCK, HYDRO-THERMAL STUDIES

ROCK.TYPE - GENERAL

REF.TYPE - PROJECT - In Situ Hydrologic Parameters Measureitents

PRINCIPAL INVESTIGATORS: UNDES, (will be coordinated with DOE and Bureau of Mines)

DURATION: -

FUNDING AGENCY: NRC.

COAMENT: This research will measure hydrologic parameters of a large mass of rock in situ, and at depth under ambient heat and water pressure conditions permitting evaluation of the containment capability of proposed sites. Measurements include: hydraulic conductivity in sealed underground chanbers; water pressure in horizontal drill holes; effective porosity; and temperature. Preparatory work under this project will include fracture mapping, borehole logging, and design and fabrication of scientific instruments. The experiment will enconpass three stages: (a) determination of amblent conditions (baseline) by measurenent of rock and water characteristics; (b) measurement of sane parameters as heat is applied; and (c) continued beasurement of the sane paraneters as the rock and water conl as the heater is turned off. 
INFORMATION SOURCES FOR THIS PROJECT: NRC WASTE MANAGEMENT PROGRAM FOR ACRS PRESENTATION, June 22, 1981.

REF.ID(S) OF ASSOCIATED DOCUMENTS: DOE

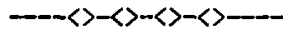

REF .ID - 94 CATEGORY - MASS TRANSPORT

ROCK.TYPE - GENERAL

REF.TYPE - PROJECT - Unsaturated Flow and Transport Thru Fractured Rock Related to High-Level Wasta Repositories

PRINCIPAL INVESTIGATORS: UNDES, (will be coordinated with DOE and USGS)

DURATION: FY 1981

FUNDING AGENCY: NRC.

COMMENT: Identify and evaluate state-of-the-art field and laboratory methods for measurement of unsaturated flow factors pertinent to determining containment capabilities of high-level waste repository sites. Factors may include infiltration rates, matrix properties liquid-vapor potentlal, volumetric molsture content, solute potential and temperature gradients. Emphasis w111 be on assessment and development of analytic methods to characterize and predict Ilquid and vapor water movement and simultaneous solute transport through unsaturated fracture rock over long time spans. Monitoring will be addressed in the fleld studies designed to evaluate state-of-the-art techniques. Both matrix and fluid chemistry will also be addressed. Lata synthesis and analyals techniques, including computer code modeling, will be performed as needed. Advance the state-of-the-art as approved by the Project officer.

INFORMATION SOURCES FOR THIS PROJECT: NRC WASTE MANAGEPENT PROGRAM FOR ACRS PRESENTATION, June 22, 1981 .

REF.ID(S) OF ASSOCIATED DOCUMENTS: NUREG, DOE, USGS

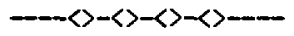


REF.ID - 95 CATEGORY - MODELING, MASS TRANSPORT

ROCK.TYPE - GENERAL

REF.TYPE - PROJECT - Ground Water Transport

PRINCIPAL INVESTIGATORS: Arizona, University of

DURATION: FY 1981

FUNDING AGENCY: NRC.

COMMENT: This project will test the validity of the current practice of predicting groundwater flow through rock by use of a model which assumes uniforn rock mass and porosity. The ongoing work in this project is evaluating existing methods for predicting groundwater flow, dispersion, and sorption of dissolved solids in fractured crystalline rocks. The results show that equations for groundwater flow in fractured rocks must be validated by field and laboratory tests to show that they are physically sound. The following will be done ti improve the predictive capability: a) mathematical formulas used to predict flow in fractured rocks will be evaluated, tested by field experiments and improved if needed. b) Analytical procedures for field injection tests and the efficiency of a group of non-toxic tracers of water movement with a range of sorptive properties will be tested and evaluated. c) Results of the field experiments will be used to examine and revise existing theory in an iterative process. d) The adequacy of existing computer programs for solving hass transport equations will be evaluated.

INFORMATION SOURCES FOR THIS PROJECT: NRC WASTE MANAGEMENT PROGRAM FOR ACRS PRESENTATION, June 22,1981 .

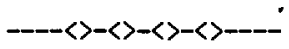


REF.ID - 96 CATEGORY - SITE SUITABILITY - ROCK/GROUNDWATER

ROCK.TYPE - GENERAL

REF.TYPE - PROJECT - Monitoring for Changes in Rock and Ground Water Cond 1 tions

PRINCIPAL INUESTIGATORS: JNDES, (will be coordinated with DOE and EPA)

DURATION: -

FUNDING AGENCY: NRC.

COMMENTS: Assess and test direct and indirect wethods for monitoring and recording the long-term effects of thertal loading and earth movement on rock deformation and stress, on the physical and chemlcal characteristics of ground water, and on the possible release of radioactive material to the environment during excavation, waste emplacement and after backfilling. Assess systematic programs for sampling and monitoring which involve consideration of optimum spatial and temporal distribution of samples and relationship between in situ and laboratory measurements. Include provisions to modify or devise new prograws as required to monitor site sultability and the hydrologic balance. Evaluate requirements for data reduction and management; and systems for feedback of collected information for consideration in design, construction, closure and related efforts

INFORMATION SOURCES FOR THIS PROJECT: NRC WASTE MANAGEMENT PROGRAM FOR ACRS PRESENTATION, June 22, 1981 .

REF.ID(S) OF ASSOCIATED DOCINENTS: NUREG, DOE, EPA

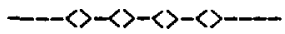


REF.ID - 97 CATEGORY - ENGINEERED BARRIERS, BOREHOLES

ROCK.TYPE - GENERAL

REF.TYPE - PROJECT - Mechanisms and Effects of Seal Degradation

PRINCIPAL INVESTIGATORS: TBD, ( will be coordinated with DOE)

DURATION: FY 1981

FUNDING AGENCY: . NRC.

COMMNTS: The characteristics and mechanisns of borehole and shaft fallure will be determined and consequences of seal degradation will be assessed relating to impacts on an operating repository and ultinate effects on the long term radionuclide containment capabilities of repositorles. The research includes: study of the effects of heat from radioactive waste, and of columnar loading, on groundwater flow as borehole or shaft seals degrade; a development of understanding of the conditions and characteristics of convection currents that could exacerbate deleterious impacts; assessment of the potential of steam driving and/or entraining water; and development of methods for predicting impacts on aquifers and radionuclide containment.

INFORMATION SOURCES FOR THIS PROJECT: NRC WASTE NANAGEMENT PROGRAM FOR ACRS PRESENTATION, June 22, 1981 .

REF.ID(S) OF ASSOCIATED DOCUMENTS: NUREG, DOE

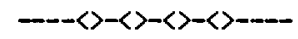


REF =ID - 98 CATEGORY - ENGINEERED BARRIERS, BOREHOLES

ROCK.TYPE - GENERAL

REF.TYPE - PROJECT - Exploratory Borehole Geochemical Measurement

PRINCIPAL INVESTIGATORS: UNDES, (will be coordinated with DOE's WRIT Program)

DURATION: -

FUNDING AGENCY: NRC.

COMENTS: Evaluate potential methods of making geo :hemical measurements such as oxidation/reduction potential and capacity, and chewical composition through exploratory borings elther from the surface or from withir an exploratory shaft or tunnel. Assess and quantify limitations and uncertainties using current techniques. Assess the need for making in-situ measurements to confirm or augment laboratory measurements and identify the costs and benefits of various techniques.

INFORMATION SOURCES FOR THIS PROJECT: NRC WASTE MANAGEMENT PROGRAM FOR ACRS PRESENTATION, June $22,1981$.

REF.ID(S) OF ASSOCIATED DOCUMENTS: NUREG, DOE, PNL

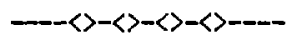


REF.ID - 99 CATEGORY - ACTINIDES/SOLUTION INTERACTIONS

ROCK.TYPE - GENERAL

REF.TYPE - PROJECT -

Natural Chemical Complexation of Actinides in Groundwater

PRINCIPAL INVESTIGATORS: Lamont, (coordinated with WRIT)

DURATION: FY 1981

FUNDING AGENCY: NRC.

COMMENS: Assess the importance of chemical complexation of actinides by comparing actinlde partitioning in natural waters bearing high carbonate, sulfate and chloride concentrations with natural waters bearing low concentrations of these anions. Emphasis will be placed on evaluating plutonium and americium derived from nuclear weapons testing fall-out so that the natural behavior of these elements over a time span of 25 to 30 years can be determined. Distribution coefficients of actinides in laboratory prepared samples will be compared with actinide distribution under actual field conditions so that the complexing mechanisms which control the natural $\mathrm{kd}$ of actinides can be defined. Bounding conditions for the transport of $\mathrm{Pu}$ and Am species in carbonate, sulfate and chloride waters will be established. The importance of oxidation state on complexing will be assessed by comparing the actinide partitioning in natural waters from oxidizing environments with waters from reducing environments. The effects of competing ions will also be evaluated.

INFORMATION SOURCES FOR THIS PROJECT: NRC WASTE MANAGEMENT PROGRAM FOR ACRS PRESENTATION, June 22,1981 .

REF.ID(S) OF ASSOCIATED DOCUMENTS: NUREG, DOE, PRL

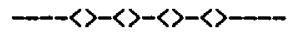


REF.ID - 100 CATEgORY - NATURAL ANALOGUES, AUSTRALILA

ROCK.TYPE - GENERAL

REF.TYPE - PROJECT - Radionuclide Migration Around Uranium Ore Bodies: Analogue of Radioactive Waste Repositories

PRINCIPAL INVESTIGATORS: (AAEC), Australian Atomic Energy Commission

DURATION: FY 1981

FUNDING AGENCY: NRC.

COMENTS: Determine rates of radionuclide migration in geologic systems using the naturally occurring radionuclides U-238, U-234, Th-230, Th-230, and Ra-226. These empirical data will be used to validate migration rates (retardation coefficients) and distances that are calculated from laboratory determined parameters and used in conceptual models of radloactive waste behavior. A natural analog will provide a means of checking the experimental values. The migration behavior of uraniun, thoriun, and radium from ore bodies if analogous in certain respects to the migration of radionuclides from breached or leaking high-level radioactive waste repositories. The Australian environment is favorable for measuring rates of radionuclide migration during the past 1000 to $1,000,000$ years for $U$, $\mathrm{Th}$, and $\mathrm{Ra}$ within a wide range of weathering and oxidation-reduction conditions. These migration rates wlll be used to assess the level of confidence that the NRC can place on transport models for licensing purposes. The AAEC w111 provide observed and laboratory geochemical data and a description of the geologic and hydrologic environment and ore body source term needed to verify existing codes. These data will be used by NRC and its other contractors in the verification of transport models.

INFORMATION SOURCES FOK THIS PROJECT: NRC WASTE MANAGEMENT PROGRAM FOR ACRS PRESENTATION, June 22, 1981.

REF.ID(S) OF ASSOCIATED DOCUMENTS: NUREG

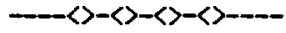


REF.ID - 101 CATEGORY - AGE DATING, GROUNDWATER

ROCK.TYPE - GENERAL

REF.TYPE - PROJECT - Confirmatory Research Related to Dating of Groundwater

PRINCIPAL INVESTIGATORS: University of Arizona.

DURATION: FY 1980, FY 1981

FUNDING AGENCY: NRC.

COHIENTS: Assess the capabilities of using isotopic ratios for groundwater dating, resolve problews of interpretation of divergent results, and test the limitations of alternative methods of ground water dating. The significance of the subsurface origin of carbon-14 and tritium will be verified in the field by testing nearly static ground water and water from aquifers rich in thorlum and uranium. The influence of hydrogeological phenomena on groundwater dating will be pursued, namely: (a) the diffusion of non-radioactive carbon lons into water-bearing fissures in dense rock, and (b) selective ion filtration by confining and/or retarding beds adjacent to aquifers.

INFORMATION SOURCES FOR THIS RROJECT: NRC WASTE MANAGEMENT PROGRAM FOR ACRS PRESENTATION, JUNE $22,1981$.

REF.ID(S) OF ASSOCIATED DOCUMENTS: NUREG

REF.ID - 102

CATEGORY - RADIONUCLIDE/GEOMEDIA INTERACTIONS

ROCK.TYPE - GENERAL,

REF.TYPE. - PROJECT - Geochemical Assessment of Nuclear Waste Isolation

PRINCIPAL INVESTIGATORS: Lawrence Berkeley Laboratory

DURATION: FY 1981

FUNDING AGENCY: NRC.

CORENTS: By neans of laboratory measurements, the contractor wijl evaluate the capabilities, limitations, and uncertainties of methods of measuring geochenical properties and of predicting radionuclide migration rates in the near field and the far field of a geologic repository. The contractor will assess the following issues and identify potential problens/inadequacies with current procedures and measurement techniques: (1) Canister/overpack-backfill chenical interactions; (2) Near-field host rock interactions and nechanisms; (3) Far field host rock interactions; (4) Adequacy of predictive models for nuclide aigration; and (5) Verification of models using geologic analogies. 
INFORMATION SOURCES FOR THIS PROJECT: NRC WASTE MANAGETMENT PROGRAM FOR ACRS PRESENTATION, JUNE 22,1981 .

REF.ID(S) OF ASSOCIATED DOCUMENTS: LBI

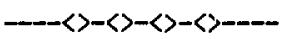

REF .ID - 103 CATEGORY - MASS TRANSPORT

ROCK.TYPE - BASALT

REF.TYPE - PROJECT - Valence Effects on Adsorption

PRINCIPAL, INVESTIGATORS: ORNL

DURATION: FY 1981

FUNDING AGENCY: NRC.

COMMENTS: Assess laboratory methods of determining valence state (and controlling $E$ ) that are being used, or could be used, in experiments on multivalent elements. The contractor will evaluate the effect of poor valence state control on laboratory measurements of distribution coefficients ( $\mathrm{Kds}$ ). The contractor will ldentify and test methods for improving the valence state control of adsorption measurements particularly under reducing conditions and compare these techniquee to standard techniques used for sorption measurements on multivalent nuclides. The contractor will conduct a limited number of measurements of sorption of $\mathrm{Tc}, \mathrm{Np}$ and $\mathrm{U}$ by basalt, sulfides and hydrous oxides and compare the results with the results of other laboratories which use standard techniques. The contractor will use electrochemical techniques to investigats the kinetics of reactions of potential repository species, that known to be impnrtant. reducing agents, with multivalent nuclides present in HLW so that the actual importance of these species on waste isolation can be assessed. The contractor will evaluate impacts of repository operation on the natural oxidation/reduction conditions and provide input for assessing the impacts of inaccurate Eh measurements on performance modeling.

INFORMATION SOURCES FOR THIS PROJECT: NRC WASTE MANAGENENT PRCGRAM FOR ACRS PRESENTATION, JUNE $22,1981$.

REF.ID(S) OF ASSOCIATED DOCUNENTS: ORNL

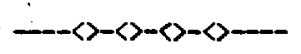


REF .ID - 104 CATEGORY - SIMULATION, WASTE/GEOMEDIA INTERACTIONS, LEACHING

ROCK.TYPE - GENERAL

REF.TYPE - PROJECT - Laboratory Analog of Waste Leaching and Migration

PRINCIPAL INVESTIGATORS: Argonne National Laboratory

DURATION: FY 1981

FUNDINE AGENCY: NRC.

COMMENTS: The rates of movement of radionuclides through laboratory analogs of breached waste 'packages and components of underground repository factlities wili be measured and the results will be compared to that predicted from results of simpler leaching and sorption tests on waste forms and geologic media. The results will also be compared with the available field data. The measurements will be conducted on a laboratory-scale model that simulates ground water flowing through a repository. Parameters to be controlled and measured in this test will be liquid flow path, flow rate, temperature, changes in substrate (mineralization), initial ground water composition, pressure, and radiation Eleld. Components of repository to be included in the tests are waste form (glass) backfill (bentonite) and near-field host rock (basait and other rocks to be specified latar). These starting materlals should include materials anticipated to be present more than 1000 years after waste enplacement.

INFORMATION SOURCES FOR THIS PROJECT: NRC WASTE MANAGEMENT PROGRAM FOR ACRS PRESENTATION, JUNE 22, 1981.

REF.ID(S) OF ASSOCIATED DOCUMENTS: ANL

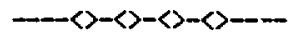




\section{REFERENCES}

American Physical Soclety, 1978. Repozt to the APS by the Study Group ort Nuclear Fuel Cycles and Waste Management. Keviews of Hodern Physics, 50, No. 1, PEII, 185 p.

Apps, J. A., Carnahan, C. L., Lichtner, P. C., Michel, M. C.,Perry, D., S1lva, R. J., Weres, O. and White, A. F., 1982. Status of Geochemical Problems Relating to the Burial of High Level Radioactive Waste, 1982, Nuclear Regul atory Commlssion Report NUREG/CR-3062, LBL $-15103,365 \mathrm{p}$.

Carnahan, C. L., 1982. Diffusional Transport of Radioactive Solutes and Colloids through a Non-Sorbing Barrier in Spherical Geometry, Letter Report to the Nuclear Regularory Commission, 65 p.

Claiborne, H. C., 1982. The Efficiency of Backflling and other Englneered Barriers in a Radioactive Waste Repository in Salt. Oak Ridge National Laboratory Report ORNL/TM-8372, 32 p.

Interagency Review Group on Nuclear Waste Management, 1979. Report to The President, U.S. Department of Energy, TID-29442. 149p plus appendices.

Kärn Bränsle-Såkerhet, 1978. Handling and General Storage of Ùnreprocessed Spent Nuclear Fuel, 1, Karn-Bränsle-Sakerhet, Stockholm, 325 p.

Klingsberg, C.; Duguid, J., 1980. Status of Technology for Isolating Highi.evel Radioactive Waste In Geologic Repositories, U.S. Department of Energy Report DOE/TIC-11207 (draft), Oct. 80, 127 p.

Smith, M. J., principal author, 1980. Englneered Barrier Development for a Nuclear Waste Repository in Basalt: An Integration of Current Knowledge, Rockwell Hanford Operations report RHO-BWI-ST-7, 05/--/80, $517 \mathrm{f}$.

J.S. Department of Energy, 1980. In. the Matter of Proposed Rulemaking on the Storage and Disposal of Nuclear Waste (Waste Confidence Rulenaking) PR-50, 51 (44FR61372) Statement of Position of the United States Department of Energy, DOE/NE-0007, 04/15/80.

U.S. Department of Energy, Office of Nuclear Waste Management and Geological Survey, U.S. Department of Irterior, 1980. Earth Science Technical Plan for Disposal of Radioactive Waste in a Mined Repository (Draft) DOE/TIC-11033.

U.S. Nuclear Regulatory Commission, 1981a. Disposal of High-Level Radioactive Waites in Geologic Repositories: Licensing Procedures; 10 CFP Part 60, Federal Register 46, No. 37, Feb. 25, 1981, P. $13980-13987$. 
This report was done with support from the Department of Enerey. Any conclusious ar opinions expressed in this report represent solely thase of tine author(s) and not necessarily those of The Rezents of the University of Catifornia, the Lewrence Berkelcy Laboratory or the Department of Energy.

Reference to a company or produet name does not imply approval or resommendation of the product by the University of California or the U.S. Department of Enerey to the exelusion of others that may be suitable. 